UNIVERSIDADE DE SÃO PAULO

FACULDADE DE FILOSOFIA, LETRAS E CIÊNCIAS HUMANAS

DEPARTAMENTO DE GEOGRAFIA

PROGRAMA DE PÓS-GRADUAÇÃO EM GEOGRAFIA HUMANA

CARTOGRAFIA E ENSINO DE GEOGRAFIA: uma breve discussão teórico-metodológica

Helaine Cordeiro Rodrigues Simião 
UNIVERSIDADE DE SÃO PAULO

FACULDADE DE FILOSOFIA, LETRAS E CIÊNCIAS HUMANAS

DEPARTAMENTO DE GEOGRAFIA

PROGRAMA DE PÓS-GRADUAÇÃO EM GEOGRAFIA HUMANA

CARTOGRAFIA E ENSINO DE GEOGRAFIA: uma breve discussão teórico-metodológica

Helaine Cordeiro Rodrigues Simião

Dissertação apresentada ao Programa de Pós-Graduação em Geografia Humana do Departamento de Geografia da Faculdade de Filosofia, Letras e Ciências Humanas da Universidade de São Paulo, para a obtenção do título de Mestre em Geografia.

Orientadora: Prof ${ }^{\mathrm{a}}$. Dr ${ }^{\mathrm{a}}$. Fernanda Padovesi Fonseca 
"Escrever é um caso de devir, sempre inacabado, sempre em via de fazer-se e que extravasa qualquer matéria visível ou vivida" (Gilles Deleuze)

Ter algo o que fazer Ter alguém para amar, Ter algo o que esperar Isto é ser feliz. (Aristóteles) 
Ao meu Deus, fiel cumpridor de Suas promessas, pela vida que me concedeu e por todos os contextos formadores dela, que me permitiram desfrutar desta oportunidade de aprendizado.

Para Antônio, Guilherme e Vinícius. 


\section{AGRADECIMENTOS}

À minha amiga e orientadora, professora doutora Fernanda Padovesi Fonseca os meus mais sinceros agradecimentos. Pela generosidade em compartilhar seu tempo e conhecimentos a fim de ampliar meus horizontes. Grata pelo privilégio de tê-la como orientadora.

Ao professor José Pereira de Queiróz Neto pelo incentivo ao ingresso na pósgraduação. Obrigada por me ouvir falar sobre o meu projeto.

Ao professor Manoel Fernandes de Sousa Neto por acreditar no meu trabalho e pela oportunidade concedida.

Ao professor Marcello Martinelli e ao professor Ricardo Mendes Antas Junior pelas sugestões, críticas e desafios propostos no exame de qualificação.

Aos amigos Gerson pela diagramação final e ao Nilton pelas traduções para o inglês.

À direção da Escola Estadual Prof. Dimarães Antônio Sandei e ao corpo docente, meus colegas de trabalho, com o qual compartilhei ideias e argumentações durante o período de aplicação da pesquisa e em especial aos alunos que participaram dela.

Aos meus amigos, pelas orações alçadas, pelo apoio e pela amizade sincera mesmo com as minhas ausências justificadas pelo trabalho necessário.

Àqueles a quem dedico este trabalho e a estes a quem agradeço, afirmo que sem vocês, eu não teria chegado até aqui. Cada um à sua maneira me orientou, ajudou, encorajou e apoiou. Esteve comigo nesta trajetória de algum modo importante, me fazendo acreditar, a cada dia, que eu seria capaz de chegar ao final deste trabalho, olhar o trajeto percorrido e sorrir, feliz.

Agradeço sinceramente a Deus, por todos vocês fazerem parte da minha jornada.

Que Ele os abençoe como tem me abençoado por tê-los comigo neste percurso. 


\section{SUMÁRIO}

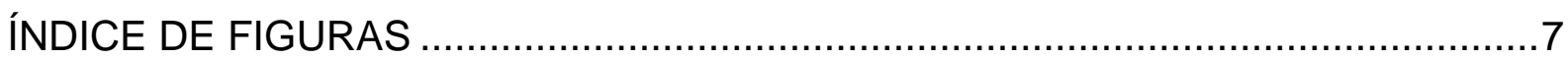

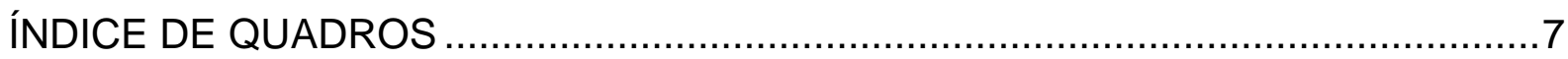

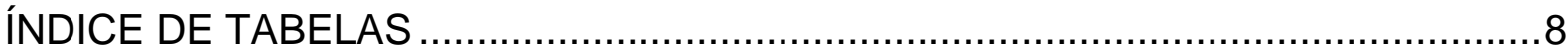

RESUMO

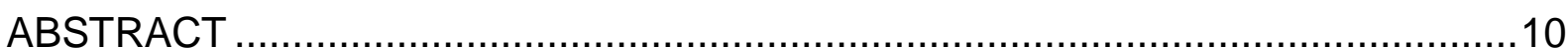

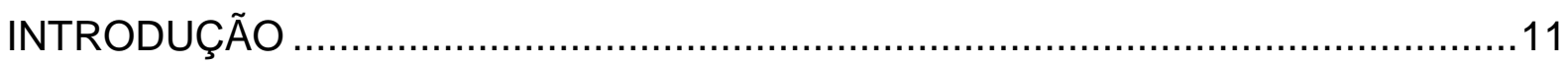

1. CARTOGRAFIA E ENSINO DE GEOGRAFIA: UMA BREVE DISCUSSÃO

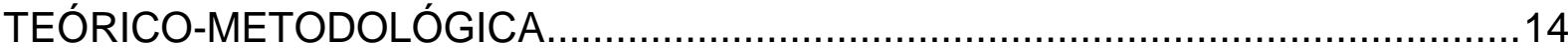

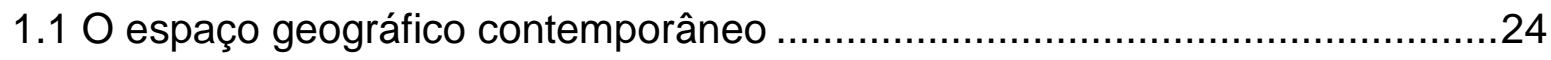

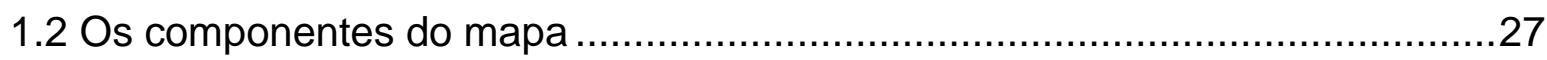

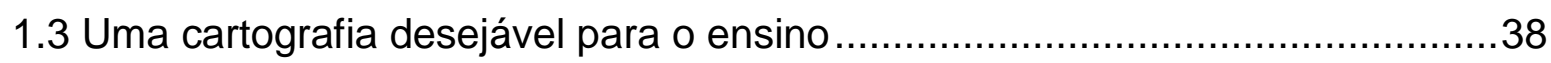

2. REFLEXÕES SOBRE A PRÁTICA PEDAGÓGICA ...........................................51

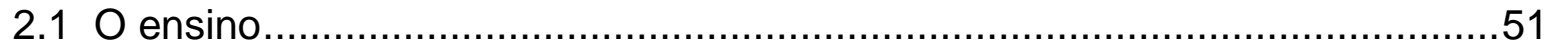

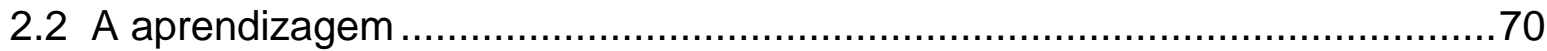

2.3 Professor: contexto de ação e formação, na prática educativa.......................75

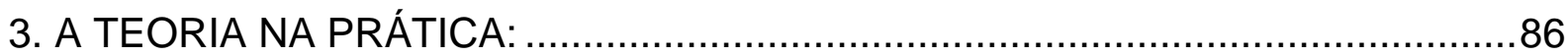

Atividades cartográficas e os conhecimentos geo-cartográficos.............................86

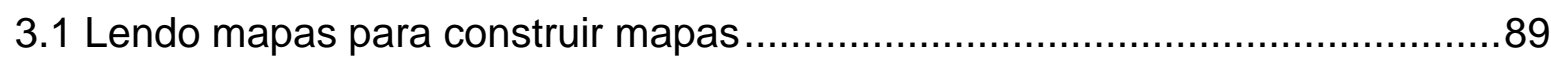

3.1.1 Alguns dos mapas iniciais: considerações críticas …………...................97

3.1.2 Atividades práticas com alunos .......................................................104

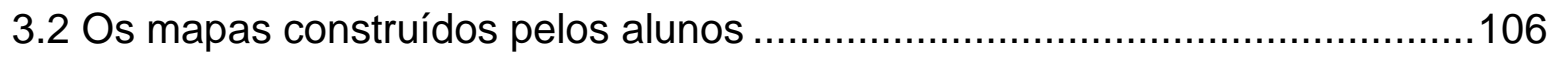

3.2.1 Outros mapas e possibilidades ........................................................117

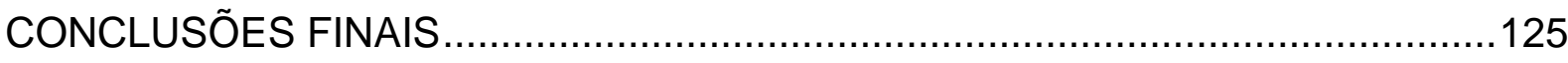

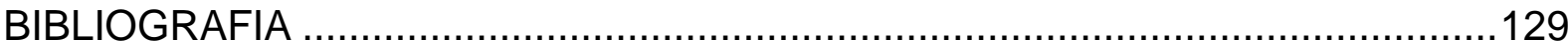




\section{ÍNDICE DE FIGURAS}

Figura 01: Anamorfose e mapa territorial........................................... 46

Figura 02: mapa 01: As migrações, final do século XX......................... 99

Figura 03: mapa 02: Esperança de vida............................................... 100

Figura 04: mapa 03: Anamorfose e mapa territorial ............................. 101

Figura 05: mapa 04: Recursos minerais do Brasil................................ 103

Figura 06: Questionário diagnóstico.................................................. 105

Figura 07: Mural de mapas construídos............................................... 107

Figura 08: Mapa resultante de atividade de copiagem.......................... 108

Figura 09: Mapa construído com aplicação da gramática dos mapas.... 109

Figura 10: Mapa sem cálculo de proporcionalidade.............................. 111

Figura 11: Mapa da população relativa................................................ 112

Figura 12: Mapa produzido sem legenda............................................ 113

Figura 13: Mapa de fluxo.............................................................. 114

Figura 14: Mapa resultante de atividade de desafio............................... 116

Figura 15: Tentativa de construção de mapa de urbanização.................. 117

Figura 16: Prova Bimestral.......................................................... 119

Figura 17: Mapa construído por aluno da EJA ..................................... 120

Figura 18: Mapa com resultado insatisfatório I.................................... 122

Figura 19: Mapa com resultado insatisfatório II................................... 123

Figura 20: Fotos de alunos em atividades......................................... 124 ÍNDICE DE QUADROS

Quadro 1: $\quad$ Os elementos do mapa................................................... 29 
Quadro 2: Representações da crise do mapa.................................. 34

Quadro 3: As variáveis visuais e as duas dimensões do plano......... $\quad 90$ ÍNDICE DE TABELAS

Tabela 1: Brasil: Urbanização................................................................ 97

Tabela 2: Tipo e quantidades de mapas produzidos........................... 106 


\section{RESUMO}

Neste trabalho procura-se discutir a linguagem cartográfica para 0 ensinoaprendizagem da disciplina de Geografia. Nesse sentido entende-se que a Cartografia é uma linguagem visual, que deve estar presente nas aulas de Geografia. Ressalta-se que, essa linguagem cartográfica deve ser ensinada desde as séries inicias do segundo ciclo do ensino fundamental. Inclusive, que deve permanecer até o final do ensino médio no currículo escolar, em todas as séries. $O$ objetivo é fazer com que os mapas façam sentido para os alunos, uma vez que, como linguagem que são, possuem um potencial comunicativo relevante no ensino e na aprendizagem. No entanto, para ficar clara a ideia do ensino e da aprendizagem que se espera efetivar, procura-se também trabalhar com autores que discutem 0 desenvolvimento da psique infantil, o currículo escolar e a escola. A intenção é compreender como ocorre o ensino e a aprendizagem e quais seriam os procedimentos didático-pedagógicos que permitiriam que esse processo se efetivasse nas aulas de Geografia. Nesse sentido foram pensados procedimentos e planos de aulas para o ensino dos conteúdos geográficos por meio do ensino da sintaxe das regras da representação gráfica conforme a Semiologia gráfica de Jacques Bertin. A partir da apreensão da sintaxe das regras da Semiologia Gráfica os alunos poderiam adquirir mais conhecimentos geográficos do que se apenas vissem os mapas temáticos como ilustração de textos. Os alunos apresentariam ganhos cognitivos e maior interesse pela disciplina de Geografia. Adquiririam também conhecimentos sobre a importância e representação dos fluxos e das redes geográficas para uma Cartografia adequada a uma Geografia renovada e perceberiam o potencial das anamorfoses para a representação do espaço geográfico como uma dimensão do social. Trabalha-se, portanto, com a concepção de espaço geográfico segundo a qual o espaço é relativo, produto da sociedade, um componente social.

Palavras-chave: Linguagem Cartográfica - Cartografia geográfica - Ensino / Aprendizagem - Espaço geográfico - Semiologia gráfica. 


\section{ABSTRACT}

In this work seeks to discuss the language mapping for teaching and learning the discipline of geography, because it understands that cartography is a visual language that must be present in geography lessons. It should be emphasized, including the need for such maps represent the geographical space as a component of society. From this understanding, we must think how to express graphically the dimension relations issues arising from central to geography such as distance, for example, in favor of school discipline Geography. In this sense it is used as the reference parameter of a desired mapping to be used in education that focuses on the relationships between objects and actions, and thus express the contemporary geographical space. For that, minimally graphical representation of the grammar should be known by students and teachers of this discipline, because it establishes that the maps must reproduce graphically the relationship of diversity, order and proportionality between the geographic objects by visual relationships of the same nature. This grammar structure of the graphic language, and if applied correctly in the construction of the map allows it to transmit the content of the information by viewing the finished map. The goal is to make theme maps make sense to students, in order to pass these students to be critical readers of maps with which we normally encounter. You can not criticize what you do not know. Accordingly, during the didactic and pedagogical procedures that allow the structuring of the cartographic language by students will be able to also develop the language of geography. It is evident that there is an urgent need for new forms of representation that are satisfaction with the new dimensionly. In this sense it has to be through the teaching of grammar syntax of the graphical representation according to Jacques Bertin's Semiology of Graphics to reach this goal. It is noteworthy that by observing the procedures suggested students also acquire knowledge about the importance and representation of geographic networks and flows to a Cartography appropriate for a geography that also is renewed. Realize even the potential of anamorphosis to represent the geographical space as a social dimension.

KEYWORDS: Cartographic language - Geographical mapping - Teaching - learning Geographical space $\quad-\quad$ graphic semiology. 


\section{INTRODUÇÃO}

O tema aqui desenvolvido surgiu no momento em que se teve contato com uma Cartografia como linguagem (BERTIN, 1980; CASTI, 2003) ${ }^{1}$ no período de graduação, concluída em 2007. A Cartografia utilizada como linguagem pressupõe uma forma de representação gráfica que apresenta a transmissão de informações instantaneamente, e se apresenta como não verbal e não sequencial. Tem uma gramática própria e inclusive, não admite ambiguidades, portanto parecia ser necessária ao ensino e à aprendizagem. Entendeu-se naquele momento que, se havia uma Cartografia com potencial de transmissão visual de conhecimentos, essa deveria ser utilizada nas aulas de Geografia, pois seria facilitadora de aquisição dos conhecimentos geo-cartográficos. Teve-se como referencial inicial 0 trabalho desenvolvido por Jacques Bertin e Roberto Gimeno (1982) o qual demonstra que por intermédio do conhecimento da gramática da representação gráfica, regida pela Semiologia Gráfica de Jacques Bertin (1967), a construção cartográfica estaria ao alcance de todos (BERTIN, 1967, BERTIN e GIMENO, 1982).

Nesse sentido surgiram inicialmente as seguintes questões: haveria uma subutilização da cartografia no ensino e na aprendizagem? Coloca-se essa questão frente à vivência de realidades do uso, e de não utilização inclusive, do mapa em sala de aula por professores, e, do não conhecimento da Semiologia Gráfica por parte dos professores de Geografia e consequentemente dos alunos.

Assim, julga-se necessário investigar algumas interrogações relacionadas ao ensino e à aprendizagem, e pretende-se buscar respostas para os seguintes pontos: A Cartografia como linguagem visual está presente nas aulas de Geografia? Os alunos sabem o que são mapas temáticos? São leitores e ou construtores cartográficos? Qual seria a Cartografia presente nos livros didáticos e nos demais materiais utilizados no ensino fundamental a partir do ciclo II? Portanto, qual seria o universo cartográfico desse público alvo? E, se houver uma Cartografia presente no

\footnotetext{
${ }^{1}$ CASTI, Emanuela. Cartographie. In: LÉVY, Jacques; LUSSAULT, Michel (Org.). Dictionnaire de la Géographie et de l'espace des societies. Paris: Belin, 2003. P.134-135. Tradução de trabalho de Fernanda Padovesi Fonseca e Jaime Tadeu Oliva.
} 
ensino de Geografia, essa Cartografia seria utilizada como facilitadora da aquisição de conhecimentos geo-cartográficos?

Ocorreu, inclusive, naquele momento, a percepção de uma questão que extrapolava a sala de aula e chegava à academia, que era a possível utilização, de formas gráficas e cartográficas de representação do espaço geográfico, que não haviam sido utilizadas a contento pela Geografia brasileira, como por exemplo, as anamorfoses.

Assim, tem-se também como objetivo levantar uma discussão teórica sobre uma possibilidade de representação do espaço geográfico com a utilização das Anamorfoses para a explicitação desse espaço como componente social. Entendese que a anamorfose, sendo uma forma de representação gráfica que altera o fundo do mapa conforme o referencial desejado seria um recurso para a cartografia que tem que dar conta da representação do espaço geográfico contemporâneo. Um híbrido (SANTOS, 2008, p.89), multidimensional que, portanto, deveria ser assim representado pelos mapas na Geografia.

Porém, e fundamentalmente, a pesquisa deveria permitir entender como aplicar a cartografia no ensino, como polo consistente de discurso, como linguagem visual.

Portanto, este trabalho se insere também na busca de reflexões sobre a aplicação prática do mapa, como linguagem, no processo de ensino e aprendizagem em Geografia, mas também nas discussões teóricas da representação espacial. E nessa direção pretende-se pensar e sistematizar procedimentos didáticopedagógicos com a utilização da Cartografia temática que permitam retomar a Cartografia como uma ferramenta desejável no processo de ensino e de aprendizagem em Geografia, eliminando uma suposta subutilização.

Procurar-se-á evidenciar, inclusive, a necessidade do ensino da gramática da representação gráfica para os alunos a partir do ciclo II do ensino fundamental.

O próprio Jacques Bertin adverte que a representação gráfica é uma linguagem rigorosamente definida e não pode ser vista como uma arte. Coloca, inclusive que nem a psicologia e nem a teoria da comunicação poderiam regê-la (BERTIN, 1980, p.168). As informações imediatas extraídas de um mapa construído conforme a gramática da representação gráfica são únicas, e apresentam apenas um significado. Como linguagem visual, a percepção instantânea é que será gravada 
na memória, por isso a necessidade de sua correta aplicação nas construções dos mapas. A interpretação dos dados presentes nos mapas resultantes e sua correlação seriam o passo seguinte nas atividades. Assim, justifica-se, a partir de uma percepção universal inicial que deverá estar expressa no mapa pronto, a necessidade do ensino da gramática da representação gráfica. O fato é que os alunos só poderão aplicar e entender algo que conhecem. 


\section{CARTOGRAFIA E ENSINO DE GEOGRAFIA: UMA BREVE DISCUSSÃO TEÓRICO-METODOLÓGICA}

Ter como foco principal o processo de ensino e aprendizagem de uma Geografia renovada é uma das propostas deste trabalho. Cuidado com o currículo e, portanto, com os conteúdos ensinados são pontos importantes que se pretende ressaltar. A priori e neste sentido, entende-se que o desenvolvimento cognitivo dos alunos é parte das considerações a serem feitas em benefício desse processo. Pressupõe-se que a cartografia, um recurso para a Geografia escolar, permita observar alguns desses critérios. Pretende-se, inclusive, evidenciar a necessidade vislumbrada na prática de ensino cotidiana, da presença de uma proposta de renovação na cartografia onde, os mapas tradicionais e os resultantes de uma proposta renovadora, devem ter presença constante no ensino. Mas, numa ótica de renovação, qual cartografia serviria à Geografia escolar? Haveria uma cartografia geográfica nas aulas de Geografia?

Sendo assim, são as reflexões sobre o processo de ensino e aprendizagem em Geografia que orientam esta pesquisa. Isso significa pensar, planejar e propor situações didáticas que possibilitem ao professor colocar em evidência todos os aspectos do conteúdo que deverá ser abordado em aula. Entende-se nesse aspecto que durante o processo de ensino e aprendizagem deverá ocorrer uma relação dialética, de forma que os alunos não sejam apenas espectadores, mas que possam interagir com o professor e o conteúdo (Cf. Garnier et al, 1996, p.12-13).

Além disso, as orientações de Maria Elena Ramos Simielli que diz: "o aluno, por sua vez, constrói ele mesmo seu saber, retendo apenas parte dos conteúdos propostos, integrando-o a sua maneira nos esquemas de pensamento e ação" (SIMIELLI, 2002, p.94), é um referencial que não se pode negligenciar nessa interação professor/aluno/conteúdo, e o qual se têm por pressuposto.

Ou seja, ensinar Geografia significa entender que mesmo com todo o cuidado na seleção do quê, de quais conteúdos se levará para a sala de aula, o desenvolvimento cognitivo de cada aluno é que determinará o quanto e quais partes desse conteúdo será apreendido. Entende-se que estas considerações devem permear todo o trabalho do professor, e as contribuições de Davidov, (apud 
LIBÂNEO, 2004), Guy Brousseau (2008) e Telma Weisz (2009) refletem também essa preocupação, e por este motivo colaboram para as reflexões realizadas.

Na prática do ensino de Geografia, especialmente em relação aos trabalhos com cartografia na sala de aula, as teorias desenvolvidas por autoras como Lívia de Oliveira $(2008)^{2}$ e Rosângela Doin de Almeida $(2008)^{3}$ são bastante expressivas e seguem nessa direção.

Em meio às ponderações sobre o processo de ensino e aprendizagem em Geografia seria conveniente pensar, portanto, que mesmo ao se ter preparado um currículo norteador, deve-se entendê-lo apenas como uma possível direção a seguir e, inclusive, observar que "[...] conceberíamos o currículo como um conjunto de hipóteses de trabalho e propostas de ação didática a experimentar, investigar e desenvolver na prática educativa" (tradução nossa). (GRUPO DE INVESTIGATION EM LA ESCUELA, G.I.E., 1991, p.5). Assim, trabalhar com cartografia em Geografia escolar, seria uma possibilidade para o ensino. Mas a adequação tanto da metodologia quanto do nível de conteúdo a ser aplicado dependerá da realidade que o professor encontrar em cada classe, a partir de uma proposta inicial que norteará o seu trabalho. E nesse sentido, conforme os resultados obtidos durante esta pesquisa pretende-se apresentar uma proposta de aplicação da cartografia em aulas de Geografia que poderá servir como sugestão de trabalho inicial à qual caberão possíveis adequações para cada situação e público alvo.

Como visto, o currículo escolar deve ser encarado como um esboço inicial de trabalho. No dia-a-dia, frente á observação das situações vividas, deverá ocorrer uma reformulação dos procedimentos didático-pedagógicos adotados pelo professor e da própria proposta didática inicialmente pensada. O professor, ao analisar atitudes e procedimentos de seus alunos, perante situações consideradas no todo, e mediante uma avaliação constante de suas próprias ações inclusive, poderá alterar o currículo.

\footnotetext{
${ }^{2}$ o capítulo "Estudo metodológico e cognitivo do mapa", originou-se da tese de livre docência de mesmo nome, apresentada no Departamento de Geografia e Planejamento do Instituto de Geociências e Exatas da Unesp, Campus Rio Claro, 1978.

3 Trabalho originado da tese de doutoramento apresentada na Faculdade de Educação da Universidade de São Paulo em 1994: "Uma proposta metodológica para a compreensão de mapas geográficos".
} 
Deve-se sempre ter em mente a concretização do processo de ensino e aprendizagem, e é preciso considerar, que se é um processo nele existe fases. Lívia de Oliveira, oportunamente, chama a atenção para o fato: "É difícil separar o ensino da aprendizagem [...] a um se segue o outro e um precede sempre o outro. Isso equivale a dizer que não existe ensino sem aprendizagem, nem esta sem aquele" (OLIVEIRA, 2008, p. 22).

Não seria o caso, então, do professor de Geografia se questionar, mais frequentemente, sobre a efetivação desse processo em sua prática educativa no ensino fundamental e médio? É o que se pretende também com este trabalho.

Neste sentido, o que poderia colaborar para alcançar esse objetivo seria trabalhar com cartografia escolar. Lívia de Oliveira destaca o papel da cartografia como instrumento para o ensino de Geografia. Entende-se que a cartografia não é por si só, uma proposta renovadora. Mas, não há dúvidas de que é uma das possibilidades para o ensino dessa disciplina, como há muito, os autores afirmam:

\begin{abstract}
Basicamente, o mapa pode ser usado em sala de aula para atingir os seguintes objetivos: localizar lugares e aspectos naturais e culturais na superfície terrestre, tanto em termos absolutos como relativos; mostrar e comparar as localizações; mostrar tamanhos e formas de aspectos da Terra; encontrar distâncias e direções entre lugares; mostrar elevações e escarpas; visualizar padrões e áreas de distribuição; permitir inferência de dados representados; mostrar fluxos, movimentos e difusões de pessoas, mercadorias e informações; apresentar distribuição de eventos naturais e humanos que ocorrem na Terra (grifo nosso). Diante desses objetivos, conclui-se que o mapa [...] deverá ser usado constantemente. (OLIVEIRA, 2008, p. 24).
\end{abstract}

Sendo assim, seria conveniente ressaltar a importância dada à presença constante do mapa nas aulas. Um fator que colabora para a presença do mapa em sala de aula é a visualização espacial do fenômeno representado, pois facilita a interpretação da informação espacial. No entanto não seria este o fator que levaria a uma subutilização desse material? Pensa-se então, o que não justificaria a subutilização do mapa, que talvez seja esse o principal motivo de, em sua maioria, os professores de Geografia utilizar os mapas apenas para "ilustrar" os conteúdos.

Lívia de Oliveira aponta para o problema quando afirma que "Parece que um problema didático do mapa está no fato de o professor utilizá-lo como um recurso visual, com o objetivo de ilustrar e mesmo 'concretizar' a realidade" (OLIVEIRA, 2008, p. 18-23). Entende-se então, conforme colocado pela autora, que ao utilizar 
esse material o professor tem a ideia de que o aluno poderá ver, de fato, a sua realidade, pois o mapa a representaria.

A autora afirma que a função do mapa em sala de aula está diretamente ligada àquilo que o professor pretende ao utilizá-lo. Se o professor não tiver claro o que pretende, ou ainda pior, se para ele o mapa servir apenas para "direcionar" as respostas dadas pelos seus alunos, o poder comunicativo do mapa é minimizado. $A$ autora chega a classificar esse professor de otimista, mas não compartilha com esse otimismo (Cf. Oliveira, 2008, p. 18-23).

Observando estas orientações procurar-se-á utilizar o mapa como produtor de conhecimentos geo-cartográficos, uma vez que se pretende aplicar atividades de construção, leitura e interpretação de mapas nas aulas de Geografia conforme a gramática da representação gráfica, da Semiologia gráfica (BERTIN, 1973) ${ }^{4}$.

Ao se pensar em como trabalhar os mapas nas aulas, é preciso retomar o grifo no trecho do texto de Lívia de Oliveira. Se for verdadeiro que o mapa permitirá "[...] inferência de dados representados; mostrar fluxos, movimentos e difusões de pessoas, mercadorias e informações [...]" (OLIVEIRA, 2008, p. 24), surge uma questão que é real na vida de muitos estudantes, principalmente os do ensino fundamental ciclo II em diante: Um aluno que reside no quarteirão que fica atrás da escola, mas que vem de fretado e demora 30 minutos para chegar a ela, não poderia ter dificuldade para entender a relação de distância, se a escala do mapa for baseada apenas numa métrica euclidiana? Não seria o caso de ser apresentada a ele outra possibilidade de entender a distância que percorre? Outras métricas não seriam mais esclarecedoras nesse caso? E os mapas de fluxo? Não deveriam ser uma constante em aulas de Geografia?

Certamente a distância métrica está lá, continua presente, mas a relação entre os objetos e a ação nem sempre serão iguais. Esse mesmo aluno, se sair a caminhar, numa prática pedestre, de sua casa até a escola, não ficaria mais confuso sobre a percepção da distância real e da distância relativa atrelada ao meio de acesso à escola? ${ }^{5}$. Verifica-se, no entanto, que os mapas utilizados no ensino

\footnotetext{
${ }^{4}$ A Semiologia gráfica é a ciência que estuda os signos. Jacques Bertin estruturou uma linguagem que possibilitou a não iniciados produzirem mapas, desde que observem criteriosamente a gramática da representação gráfica de dados, conforme a Semiologia gráfica. Pode-se afirmar que essa gramática torna a cartografia mais democrática.

${ }^{5}$ Informação verbal de aula em 04/2007 no Centro Universitário FIEO. UNIFIEO, Osasco - SP
} 
fundamental e médio comumente utilizam apenas a métrica euclidiana para a representação de qualquer fenômeno. Independentemente da relação estabelecida, se for uma relação distância-tempo ou uma relação de distância absoluta, a métrica é sempre a mesma.

Empiricamente observa-se que o aluno não tem, necessariamente, noção da diferença entre distância relativa e distância absoluta, no entanto, o que ele vive é relativo. Cabe à Geografia escolar fazê-lo entender essa relação. Se o aluno em sua realidade vivenciar uma métrica diferente daquela que ele aprende em sala de aula, e na sala de aula os mapas com os quais ele tiver contato não derem conta de representar a realidade vivida, as explicações dadas em aula não permitirão que os mapas façam sentido. E neste caso, Fernanda Padovesi Fonseca e Jaime Tadeu Oliva chegam a identificar uma "cartografia primitiva" que seria utilizada para representar um espaço social, essencialmente humano, o que seria inviável (Cf. Fonseca e Oliva, 2002, p. 76).

Ainda com o trabalho de Lívia de Oliveira acima mencionado, no qual a autora afirma que o mapa permitirá a inferência de movimentos de pessoas e de informações, precisa-se considerar que neste caso o mapa deverá ser utilizado em sala de aula de maneira adequada para alcançar essa finalidade entre outras. Portanto, pessoas, informações e mercadorias que estão em movimento devem ser representadas por mapas dinâmicos. Esses movimentos formam, inclusive, redes geográficas que precisam ser representadas para serem utilizadas para explicitar, por exemplo, algumas relações no contexto urbano, ou mesmo a globalização na contemporaneidade. Mapas que evidenciassem fluxos e redes geográficas não deveriam ser mais comuns em sala de aula?

Não se propõe aqui que os alunos os construam desde o ciclo II do ensino fundamental, mas que tenham, pelo menos, acesso a esse tipo de material mais comumente, devido ao seu poder explicativo da realidade.

No entanto, haveria nas aulas de Geografia material cartográfico que permitisse a visualização dos fluxos e das redes geográficas? Esse material seria conhecido dos alunos? Eles poderiam lê-los com propriedade caso se deparassem com um mapa de fluxo numa avaliação externa à escola básica, por exemplo? Num mundo imagético, certamente essa necessidade ocorrerá. 
É preciso destacar que caberia ao professor de Geografia, entender o espaço como relativo-relacional (Cf. Lévy, Lussault, 2003) ${ }^{6}$ e tê-lo claro para si, para poder, por intermédio dos mapas que representem esse espaço como tal, torná-lo visível e compreensível para os seus alunos. É o que Patrick Poncet ${ }^{7}$ fala:

[...] qualquer mapa deve levar em conta e traduzir um pensamento geográfico que o preexiste - o que pressupõe uma teoria do espaço, mesmo que apenas implícita ou mesmo inconsciente - [...] (PONCET, 2011, p.01).

Esse professor não poderia se tornar o orientador de novas possibilidades para a aplicação da cartografia no ensino, junto a seus alunos? Poderia ser por intermédio dessa intervenção que deixaria de haver uma cartografia primitiva nas aulas de Geografia e surgiria uma cartografia escolar renovada?

No trabalho de Lívia de Oliveira, quando a autora resgata o posicionamento de Mettenet (1968), é possível perceber como o mapa tem sido visto por estudantes de Geografia: "todo o mapa é quase sempre uma frustração, para aqueles que desconhecem o processo de mapeamento" (METTENET, apud OLIVEIRA, 2008, p. 23). O que se propõe é que o professor de Geografia explore melhor as possibilidades do mapa em sala de aula. Ele, professor, será o mediador para evitar que o mapa continue sendo uma frustração para os alunos. E neste caso, um mapa explicativo da realidade, teria um significado positivo e não de frustração.

Ao se trabalhar com mapas nas aulas de Geografia o processo de generalização, a escala, a projeção e o simbólico devem ser apresentados aos alunos com esse objetivo, inclusive (Cf. Castrogiovanni, 1995, p. 149-155).

E nessa direção tem-se também o trabalho de Jacky Fontanabona ${ }^{8}$ como um referencial para a discussão da utilização do mapa em aulas de Geografia. $O$ autor apresenta o mapa como uma linguagem visual, que pode ser complementada pela

\footnotetext{
${ }^{6}$ Lévy, Jacques e Lussault, Michel. Espace. IN : Dictionnaire de la Géographie et de l'espace des sociétés. Paris: Belin, 2003. p. 325-333. Tradução de trabalho de Monica Balestrin Nunes, jul./2009 com comentários de Jaime Tadeu Oliva.

${ }^{7}$ Todas as citações do mesmo autor, doravante remetem a: PONCET, Patrick. Visioni del Mondo. In: Inventare II Mondo. Una geografia della mondializzazione. Disponível em http://www.inventareilmondo.net/ Acesso em 23/08/2011. Tradução de trabalho de Ludmila GirardiAlves.

8 FONTANABONA, Jacky. Langage cartographique et connaissances géographiques. http://ecehg.inrp.fr//ECEHG/enseigner-apprendre/langage-cartographique/langagecartographiquefontanabona-pdf.pdf. Texto inédito de Jack Fontanabona professor associado à INRP, da área de pesquisa sobre as "Cartas e modelos gráficos. Análise de práticas em classes de geografia" (19992002) . Acesso em 10/11/2009. Tradução nossa.
} 
linguagem verbal, mas insiste que como toda a linguagem, deve ser ensinada. Portanto, o professor de Geografia deve também reconhecer esse potencial do mapa, assim como a necessidade de levá-lo para a sala de aula como uma linguagem e não apenas como uma ilustração.

Esse mesmo autor ressalta os problemas decorrentes de se trabalhar com mapas e croquis com o que ele chama de práticas escolares pobres. Como exemplo menciona utilizar os mapas tendo como primazia a linguagem verbal. Nesse trabalho - autor afirma que a cartografia na sala de aula continua estagnada na representação clássica dos objetos, que comumente os alunos reproduzem. Ressalta, no entanto, o seu potencial como linguagem e que inclusive, essa linguagem deve ser ensinada como uma prática de renovação no ensino. Ele afirma que os professores de Geografia se intitulam especialistas em trabalho com mapas no ensino, mas é crítico dessa postura, pois questiona: utilizam-nos para fazer o quê? (Cf. Fontanabona, 2002, p.01).

Aliás, os trabalhos como os de Jacques Bertin e Roberto Gimeno (1982) ${ }^{9}$, inclusive, já evidenciavam com propriedade a importância dos trabalhos com cartografia escolar onde há o ensino da linguagem cartográfica. E é necessário colocar que, nesses trabalhos, há uma proposta de aplicação da cartografia com base em exercícios de construção de mapas, e não apenas a simples leitura desse material ou a simples reprodução de objetos. É também nessas propostas de trabalho didático-pedagógicos que esta pesquisa está embasada.

Como citado, para o caso da possibilidade de propostas de renovação, cabe ao professor conhecê-las e trazer mapas dentro dessa perspectiva para as salas de aula, para que os alunos se familiarizem com elas. A necessidade premente, ao menos inicialmente, no entanto, é fazer com que os alunos aprendam a gramática da representação gráfica, para poder ler e construir mapas por meio de sua aplicação no ensino de Geografia.

Afirma-se que a Semiologia gráfica estruturou a gramática dos mapas. Portanto a linguagem cartográfica só pode ser escrita se essa gramática for observadas.

Neste sentido os trabalhos com cartografia na sala de aula são propícios ao desenvolvimento cognitivo, pois, permitem, por exemplo, que o professor, após

\footnotetext{
${ }^{9}$ Trabalho de Jacques Bertin e Roberto Gimeno com atividades cartográficas para alunos da escola elementar, publicado em 1982, tradução de Antônio Teixeira Neto.
} 
ensinar a gramática da representação gráfica, proponha trabalhos em grupo onde os alunos terão participação efetiva. Entende-se, no entanto, como já mencionado, que ao professor cabe pensar situações didáticas que considerem os diferentes níveis de desenvolvimento dos seus alunos, que devem trabalhar em grupos, inclusive. Portanto, já considerar que mesmo alunos de uma mesma idade, podem estar em níveis de desenvolvimento cognitivos diferentes (Cf. Cavalcanti, 2005, p. 187).

A opção em trabalhar com pequenos grupos, e deixar em aberto a troca de informações entre eles, surgiu também segundo as orientações de Catherine Garnier (Cf. Garnier et al, 1996, p.11). Sendo assim, entende-se que poderá ocorrer entre os estudantes a troca de argumentações, de propostas de soluções a problemas que surgirem durante a atividade de construção cartográfica observando as regras da gramática da representação gráfica, o que lhes possibilitará avançar para outros níveis de desenvolvimento (Cf. Bertin e Gimeno, 1982, p.35-56, Bertin, 1986, p.01-12).

Observe-se também que "a linguagem faz parte da prática, e é na prática que as pessoas aprendem" (LAVE E WENGER, 1991, p.85, apud DANIELS, 2003, p.97). Os referidos autores tomam como exemplo de suas colocações a utilização da linguagem verbal, escrita, inclusive. Os autores afirmam que a prática faz parte do e é essencial no processo de ensino e aprendizagem. Assim, o critério utilizado com relação à aplicação de exercícios com mapas, que se observa nos trabalhos dos autores que introduzem a cartografia enquanto linguagem no ensino é a preocupação em levar o aluno a realizar atividades; a praticar. Portanto, de acordo com o proposto neste trabalho, para que realmente ocorra a aprendizagem.

Entende-se que o conceito de atividade é o motivador da preocupação dos trabalhos em grupo onde a criança somente pode apropriar-se do ambiente cultural enquanto ser ativo:

\footnotetext{
Analisando a estrutura da atividade, Leontiev (1975) demonstrou que essa surge após a manifestação de uma necessidade (grifo da autora). [...]a necessidade, ou o motivo, não é ligado unicamente a um objeto material, podendo ser, como é freqüentemente o caso, um objeto ideal (idéia, modelo, etc.). Para ser atingido diferentes ações devem ser executadas pelo sujeito (GARNIER et al, 1996, p.12-13).
}

Sendo assim, entende-se que a proposta de trabalho em sala de aula, com exercícios de construção de mapas, após o ensino da gramática da representação gráfica, trará aos alunos a necessidade de decidir-se entre os signos mais 
adequados para que eles produzam mapas para ver, inclusive. Pressupõe-se que se os alunos forem capazes de produzir esses mapas, todos os outros mapas com os quais eles tiverem contato, não serão uma frustração para eles.

Em relação aos procedimentos didático-pedagógicos que envolvem o trabalho do professor, durante a análise do processo de construção dos mapas poder-se-ia saber de imediato, se e como se reformularia a atividade para alcançar os objetivos propostos na situação de aprendizagem ou se as reformulações não serão necessárias, pois os objetivos propostos incialmente foram alcançados. O que pode auxiliar na análise dos referidos procedimentos é o resultado final dos mapas construídos pelos alunos, incluindo-se aí os procedimentos e atitudes deles durante as atividades.

Mas, deve-se ter em mente também que a gramática da representação gráfica possui limites (Cf. Bertin, 1986, p. 12), e assim, existem alguns cuidados que o professor não pode deixar de observar.

Fernand Joly fala das qualidades didáticas e legibilidade dos mapas, informa que o mapa deve cumprir plenamente o seu papel de comunicação. Diz que a real expressividade dos mapas está em atrair convenientemente a atenção do leitor para os aspectos mais importantes nele tratados. Chama a atenção para o fato de que, se as informações nele contidas forem tomadas em separado e isoladamente, ele não servirá mais do que para uma mera localização. Destaca a necessidade de trabalhar, por intermédio do bom mapa, as relações dialéticas e hierárquicas ali estabelecidas entre os objetos. As suas observações caminham na direção de alertar o cartógrafo para evitar uma simbologia confusa, equívoca ou mesmo irracional. A qualidade de legibilidade estará presente quando facilmente se encontrar a informação desejada, mas neste caso deve haver um limite, para que a percepção visual ocorra plenamente (Cf. Joly, 1990, p.120-122).

No trabalho que se pretende realizar em sala de aula opta-se por seguir suas orientações ao trabalhar com documentos que não sejam carregados de informações. Outra escolha é, inclusive, produzir vários mapas fáceis de decifrar. 0 que se considera é que, principalmente, se estará trabalhando com crianças e adolescentes que devem aprender sobre as bases da linguagem dos mapas e por intermédio delas adquirir conhecimentos geográficos. Pretende-se, a partir da localização do fenômeno, levar os alunos a observar as relações dialéticas e 
hierárquicas neles estabelecidas por intermédio de discussões em aula expositiva que se seguirá à construção de cada um dos mapas.

Têm-se também como norteadores os encaminhamentos de Jacques Lévy que corroboram para a explicitação da linguagem dos mapas, as quais ele classifica como não verbais e não sequenciais. A 'leitura espacial' não é um ler, mas é um ver. Portanto, ao trabalhar com a linguagem dos mapas surge a necessidade de um tratamento visual do objeto representado, que privilegie o olhar instantânea e globalmente. Pois, para uma apreensão visual instantânea, há também uma limitação das informações. Se o fenômeno deve ser apreendido instantaneamente, não é possível sobrecarregar a imagem. Isso irá prejudicá-la. O olho humano não capta muitos caracteres ao mesmo tempo (Cf. Fonseca, 2004, p.204).

O ideal seria trabalhar com as propriedades perceptivas que toda a transcrição gráfica deve levar em conta, na busca de traduzir as relações fundamentais que são três: de diversidade, de ordem e de proporcionalidade. As cores merecem especial atenção, pois necessitam de um conhecimento específico dentro do espectro eletromagnético (Cf. Martinelli, 2008, p.18). O professor deve ter cuidado ao trabalhar com elas, uma escolha entre cores opostas, por exemplo, uma cor fria em oposição a uma cor quente, para representar fenômenos que devem ser hierarquizados pode não ser tão simples, pois, embora opostas, poderão ter o mesmo nível de apreensão pela retina. Esclarece-se, em tempo, que não se pretende utilizar cores nas atividades de construção de mapas pelos alunos nesta pesquisa.

Com relação ao tratamento dado ao mapa, e na busca de um bom mapa, resgata-se o que Lívia de Oliveira coloca, já que discute o mapa na sala de aula, embora não o apresente dentro de uma proposta renovadora para as discussões perpetradas neste trabalho, qualifica-o da seguinte maneira:

[...] o bom mapa é aquele que apresenta corretamente o que queremos mostrar. Os critérios básicos para selecionar um bom mapa são os seguintes: legibilidade, simplicidade e utilidade do conteúdo ou dos dados. Mas pode-se acrescentar que o mapa, como forma de comunicação gráfica, precisa transmitir sua mensagem de maneira clara, rápida e efetiva. Mais importante ainda é que os receptores dessa mensagem, quando emitida em uma sala de aula, são crianças e adolescentes que se encontram em diversas etapas de seu desenvolvimento intelectual. (OLIVEIRA, 2008, p. 24). 
Assim, se pretende trabalhar com bons mapas, o professor de Geografia, de imediato, tem que ter claro o que ele quer mostrar em suas aulas por meio desse material. Primeiro: que o mapa deve servir para representar o espaço geográfico. Segundo: ter clareza de qual é a conceito de espaço geográfico que ele quer apresentar para seus alunos.

Todavia, é preciso esclarecer que, mesmo um mapa construído com critério conforme a gramática da representação gráfica, que for utilizado apenas como ilustração, não cumpre o seu papel de "polo consistente de discurso", como afirma Fernanda Padovesi Fonseca (FONSECA, 2004, p. 212). Por este motivo as atividades que se pretende aplicar terão início com a construção dos mapas, e a partir dos mapas já construídos pelos alunos, se iniciará a discussão de cada tema. Por exemplo, o mapa que trata do trabalho infantil será complementado com discussões em aula expositiva que abordará as condições de trabalho, ilegalidade, sua distribuição em cada região brasileira, mencionando, inclusive, os trabalhadores infantis dos semáforos em São Paulo, fato que é visível a muitos dos alunos.

Sendo assim, colocadas estas observações iniciais as quais se entende sejam necessárias para a reflexão que se fará a seguir, apresenta-se então a concepção de espaço geográfico presente nesta pesquisa. Posteriormente se esclarecerá sobre as possibilidades de renovação para o ensino de Geografia por intermédio da utilização do mapa como uma linguagem na escola básica a partir do ciclo II.

E nesse sentido será preciso esclarecer o que se entende, nesta pesquisa, seja um mapa adequado para a representação do espaço geográfico contemporâneo. Essa questão será retomada mais adiante, pois se acredita que talvez seja conveniente primeiro se posicionar com relação ao conceito de espaço geográfico que aqui se adotou, como já informado.

\subsection{0 espaço geográfico contemporâneo}

É da representação do espaço geográfico que a cartografia terá que dar conta. Para Patrick Poncet a cartografia deve se apressar se pretende cartografar a mundialização, como um fenômeno geográfico que é. Segundo o autor, representar a mundialização é tão difícil quanto contraditório "com os princípios fundadores do mapa e em menor medida com aqueles da cartografia" (PONCET, 2011, p. 01). 
Entende-se que a Geografia escolar deva conceber e aplicar uma cartografia que seja cognitiva e facilitadora da explicitação desse espaço.

Mas, antes de entrar na discussão sobre qual seria a cartografia desejável para o ensino, inclusive, é preciso destacar, primeiramente, que nesta pesquisa adota-se o conceito de espaço geográfico apresentado por Milton Santos: "O espaço é, como pretendemos, um resultado da inseparabilidade entre sistemas de objetos e sistemas de ações" (SANTOS, 2008, p. 100).

Fernanda Padovesi Fonseca traz alguns exemplos de inseparabilidade entre os sistemas citados. A autora afirma que um rio, é um objeto natural, mas sobre o qual a sociedade coloca uma finalidade, dá a ele uma função. $O$ rio, atrelado a um sistema de objetos, sendo um objeto natural está em relação com e por um sistema de ações. Seria conveniente pensar, inclusive, nas reservas biológicas ou minerais, objetos naturais, mas que têm uma finalidade exploratória para atender às sociedades. Portanto, objetos naturais humanizados pelas funcionalidades dadas a eles pelos seres humanos, e que estão em relação (Cf. Fonseca, 2004, p. 38-39). Sistemas de objetos e sistemas de ações.

Todavia, embora pareça esclarecedora a definição do conceito, autores como Jacques Lévy e Michel Lussault ${ }^{10}$ apresentam a dificuldade verificada para abordar o conceito de espaço geográfico por boa parte dos geógrafos. Os autores afirmam que é visível uma relutância à dedicação ao trabalho de aprofundamento teórico do significado do conceito, uma vez que se pode pensar em um silêncio seguro na ideia que a expressão 'espaço geográfico' designaria um conjunto cognitivo claro que se imporia a todos. No trabalho mencionado os autores apresentam uma discussão sobre o conceito de espaço ao longo da "evolução" da Geografia. Finalmente afirmam que é possível entender o espaço como uma grande quantidade de espacialidades indissociáveis, em cada realidade. Portanto, embora a realidade espacial não seja única, sendo real, formada de mais de uma espacialidade, assim deve ser representada pelos mapas. Mas, como?

Destacam, inclusive, que o espaço não é entendido como um fator determinante sobre a sociedade, mas construído por ela para ela. "O espaço está

\footnotetext{
${ }^{10}$ As considerações apresentadas a seguir se baseiam no trabalho destes autores. Lévy, Jacques e Lussault, Michel. Espace. IN : Dictionnaire de la Géographie et de I'espace des sociétés. Paris: Belin, 2003. p. 325-333. Tradução de trabalho de Monica Balestrin Nunes, jul./2009 com comentários de Jaime Tadeu Oliva.
} 
dentro da sociedade e a expressão 'relação espaço/sociedade' deve ser concebida como uma relação de uma parte com o todo, do mesmo modo que 'política/sociedade' ou 'indivíduo/sociedade” (LÉVY, 1994, p. 47, apud OLIVA, 2001, p. 28).

Segundo esses autores há uma superioridade nesse tipo de abordagem do espaço, uma vez que por meio dela o espaço é visto e compreendido como relativorelacional, já que permite inseri-lo como dimensão de um universo complexo que é o que se vivencia.

Apesar de sua complexidade, o espaço seria totalmente explicativo à medida que pode ser entendido pela análise das construções sociais ao longo da história, realizadas inclusive, para satisfazer às necessidades sociais em quesitos atrelados à sua relação com as distâncias. Como transpor as distâncias, como agir de maneira a permitir o mínimo afastamento desejável? Ou ainda, como gerir grandes distâncias para obter mais lucros ou para permitir a mobilidade de pessoas, mercadorias e informações, por exemplo.

A questão é que as sociedades vêm operando transformações no espaço para administrar as suas formas de se relacionar. Questões de acessibilidade, de co-presença ${ }^{11}$ ou de afastamentos, são centrais. Estas remodelaram o espaço durante a história da humanidade.

Nessas diferentes necessidades de resolução de problemas espaciais o espacialismo de Descartes é apenas uma possibilidade entre outras que coopera para a análise espacial, mas não deve ser a única. Inclusive há certa formalização do espaço por intermédio dessa geometria. Segundo os autores, essa formalização é secundária para tratar as realidades.

Sugerem então a superioridade de uma abordagem relativa-relacional. O caso é que, sob este ângulo, o espaço é inserido como dimensão de um universo complexo. Sendo que ele é apenas uma parte do todo.

Ressaltam que a abordagem do espaço leibniziano permitiria fazer discussões do espaço como um veículo para percorrer fatos sociais em conjunto, conforme os autores colocam. Existiria inclusive, nessa abordagem, uma resistência

\footnotetext{
11“Co-presença é a razão de aproximação sensorial, que é decisiva nas sociedades humanas” (FONSECA, 2004. P.38).
} 
à analogia entre espaço e território, que fechado e autossuficiente, não caracterizaria o espaço pelas suas dimensões espaciais.

Afirmam que o espaço não seria explicativo por si mesmo, mas apenas e unicamente, em relação a um todo social.

Assim, para evidenciar uma teoria global dos espaços da sociedade Jacques Lévy e Michel Lussault sugerem uma definição do espaço centrada nas relações sociais. A distância é referência. Interconectadas a ela estão: Co-presença, mobilidade e telecomunicações. Estes conjuntos de análise seriam concorrentes e ao mesmo tempo complementares.

Esse arcabouço teórico permite afirmar o princípio da realidade do espaço. Essas classificações permitem a verificação do espaço como um conjunto de objetos em relação. Lugar/área se imporiam, e a análise do espaço relativo na relação de distância seria evidente. Co-presença, mobilidade e telecomunicações se interrelacionariam para configurar o espaço que permite e leva a determinado tipo de relação social.

Percebe-se então a questão da distância. Mas há a necessidade de se buscar algumas considerações sobre ela.

Admite-se, a priori, que o espaço não pode ser mensurado e representado apenas por intermédio da métrica euclidiana.

Sendo assim, sugere-se que para uma Geografia escolar eficaz, haveria a necessidade de se assumir o espaço como societal, relativo e relacional. Esta maneira de entender e analisar o espaço, é que explicaria a realidade do aluno.

\subsection{Os componentes do mapa}

A proposta deste trabalho é avançar na discussão sobre o mapa na busca de uma linguagem cartográfica que apresente uma cartografia geográfica. Para esse fim será preciso observar alguns elementos do mapa mais detidamente.

Ao pensar sobre o mapa, tem-se que a linguagem cartográfica está presente em todos os seus elementos: na escala, na projeção, na métrica e no simbólico (FONSECA, 2007, p.107).

Esclarece-se, em tempo, que nesta pesquisa optou-se por trabalhar em sala de aula com atividades práticas apenas o elemento denominado "simbólico", pois é 
nele que é evidente a aplicação da gramática da representação gráfica, regida pela Semiologia gráfica.

Para compreender o mapa tem-se que:

\begin{abstract}
"O mapa muda. Ele é posto em movimento sob a quádrupla influência de seu referente (os espaços que ele busca representar), dos conceitos que colaboram para pensar esses espaços [...]"[...] O lócus de produção da cartografia é societal, na medida em que ele concerne, ao mesmo tempo, o conhecimento teórico e a vida cotidiana, a linguagem e a tecnologia, o econômico e o político. (LÉVY, 2008, p.153).
\end{abstract}

O que o autor esclarece é o diálogo que deve haver entre linguagem cartográfica e linguagem geográfica.

Entendendo-se que um espaço societal não é imutável, mas moldado às necessidades da sociedade, intui-se que ele apresenta-se, sob vários aspectos, multimétrico, inclusive.

Dando sequência à interpretação e desmitificação do mapa e do espaço que ele representa é preciso também evidenciar que os mapas são modelos de representação de um referente (BOARD, 1975). Este referente, como coloca Jacques Lévy, são os espaços, portanto mais de um tipo de espaço deve ser representado pelos mapas. Assim, tem-se um embasamento teórico que permite afirmar a multiplicidade de categorias de espaço que, portanto, não podem ser representados apenas e unicamente pela métrica euclidiana, pois haveria uma incompatibilidade entre o referente e aquele objeto que o representaria, o mapa (Cf. Fonseca, 2004, p.225). E como Patrick Poncet afirma, verifica-se uma contradição e uma dificuldade, na contemporaneidade, em se representar a mundialização, por exemplo, se para tal for utilizada a cartografia de maneira convencional, já que "o quadro convencional que define especificamente o mapa faz eco apenas marginalmente com o quadro conceitual da mundialização" (PONCET, 2011, p. 01).

Considera-se importante trazer o que Jacques Lévy apresenta sobre a linguagem cartográfica que estrutura o mapa.

No quadro número 01 o autor apresenta os elementos do mapa, e a partir dessa apresentação, se procurará discutir cada um desses elementos considerados na aplicação de uma Geografia emersa num processo de renovação. 
Quadro 1: Os elementos do mapa

\begin{tabular}{|l|l|}
\hline Elementos indispensáveis do mapa & Função e posição \\
\hline Escala & $\begin{array}{l}\text { Contexto, redução da área (fundo do } \\
\text { mapa) }\end{array}$ \\
\hline Projeção & $\begin{array}{l}\text { Contexto, controle de deformações } \\
\text { (fundo do mapa) }\end{array}$ \\
\hline Métrica & $\begin{array}{l}\text { Contexto, definição de áreas (fundo do } \\
\text { mapa) }\end{array}$ \\
\hline Simbólico & Informações projetadas no fundo \\
\hline
\end{tabular}

LÉVY, Jacques, apud FONSECA, 2004, p.238.

Procurar-se-á destacar inicialmente a questão da métrica, pois é bastante significativa para a análise do que poderia realmente representar o espaço geográfico contemporâneo.

Segundo o autor, a função deste elemento do mapa é, dentro do contexto, ou seja, do que se pretende que o mapa represente, de qual será a sua utilização, definir áreas. É com o fundo do mapa que a métrica será visualizada. Ela está diretamente ligada à geometria euclidiana, com lógica própria, e é apresentada apenas, como a única opção de medir um espaço, mas um espaço específico, o espaço euclidiano. Segundo Patrick Poncet tem-se:

Verdadeiro e próprio pecado original do cartógrafo, o euclidianismo designa o fato de que o mapa não pode ser outro (grifo nosso) que uma representação plana do espaço, enquanto este último não está em um plano. O espaço da sociedade é um conjunto das relações tecidas das distâncias entre os componentes da sociedade [...] O único meio de representar o espaço geográfico em toda a sua complexidade não euclidiana consiste em usar subterfúgios simbólicos e deformações, como se faz - a exemplo - com a ajuda das anamorfoses (PONCET, 2011, p.02).

Assim, poder-se-ia entender que a métrica euclidiana deve ser vista como uma das possibilidades, ao lado de outras métricas, para a representação do espaço geográfico, do qual o euclidiano faz parte. 
Se, como afirma Jacques Lévy, deve haver um diálogo entre linguagem cartográfica e linguagem geográfica, retoma-se o componente distância, para a análise e na representação do espaço. Admite-se, no entanto, que apenas apontar a existência das distâncias não seria produtivo, pois toda a sociedade se organiza na articulação das dimensões, tais como a econômica, a temporal, a individual. Esta constatação decorre do papel fundamental do espaço na vida dos homens, devido à distância existente entre os objetos da sociedade. Por exemplo, como transpor distâncias para permitir a co-presença faz com que os homens, atores/agentes sociais, pensem como refuncionalizar ${ }^{12}$ o seu espaço vivido. Portanto a ideologia, as tecnologias, as estratégias de ação, acabam por configurar o espaço. Assim, as relações espaciais não podem ser mensuradas apenas por aproximação de medidas da posição entre os objetos.

Analisar plenamente as distâncias e os jogos dos operadores consiste em
abordar o espaço como o conjunto de relações espaciais, sob suas formas
materiais, imateriais e ideais, estabelecidas por uma sociedade em um dado
momento entre todos os objetos societários distintos - sendo os indivíduos
constituindo, é claro, os objetos da sociedade (LÉVY, LUSSAULT, 2003,
p.325-333).

Segundo os autores trata-se então de um espaço multidimensional com recusa ao termo sócio espacial, uma vez que o social é intrínseco ao espaço, é espaço geográfico.

Enfatiza-se aqui que a partir da gramática da representação gráfica (BERTIN, 1967) se pode avançar muito nessa direção, desde que se entenda que a cartografia deve representar também esse espaço, que é relacional. Esta observação é principalmente verdadeira para o potencial de disciplina social que é a Geografia.

Destaca-se, com a finalidade de embasar esta discussão, o que Patrick Poncet apresenta:

[...] respeitando a desigualdade que estabelece que a distância mais breve entre dois pontos é sempre uma reta. Se isto é verdadeiro no espaço da geometria euclidiana, que é também aquele do papel sobre o qual se traça o mapa, é ao contrário tudo falso no espaço geográfico, (grifo nosso) porque a distância medida em tempo de percurso sobre dois lugares varia em

\footnotetext{
${ }^{12}$ Segundo Ricardo Mendes Antas Junior (O Lazer paulistano nas diferentes fases da modernização da cidade) embora Milton Santos use o termo 'reestruturação constante' ao se referir às alterações operacionalizadas no espaço geográfico pelas sociedades, o ideal seria o termo refuncionalização. O que ocorreria, segundo ele, seria a troca da função de um determinado objeto ao longo da história, dependendo da necessidade da sociedade que define o seu uso.
} 
função do sentido de deslocamento, do momento, do itinerário antes que da forma (linha reta, curva, etc.) do traçado (PONCET, 2011. p. 02).

Essa forma de entender o espaço, essa nova visão sobre o espaço, surge a partir dos anos 1980, quando então emergem questionamentos espaciais em várias ciências para poder compreender o espaço como societal.

Discussões sobre o processo de globalização emergem e Christian Grataloup afirma que o nível geográfico do mundo não é mais um simples quadro ou uma soma de regiões, mas que deve ser entendido como um sistema (Cf. Grataloup, 2009).

Questões centrais para a Geografia passam a ser a distância e os lugares. A gestão das distâncias seria fundamental para a compreensão do processo de globalização que se estabelece na contemporaneidade, mas com muitos enclaves em áreas que não a econômica. O fato é que na globalização emergem outras distâncias além daquela relacionada à métrica euclidiana, que representa a distância absoluta e que tornam evidente a necessidade de análise do todo.

Para uma linguagem cartográfica que dialogue com a linguagem geográfica, a métrica é bastante esclarecedora da necessidade de renovação dos paradigmas cartográficos frente à urgência em representar as redes geográficas, por exemplo, que configuram o espaço geográfico contemporâneo (Cf. Badie, Bertrand, 2006, apud DURAND, 2006, p. 437).

Marie-Françoise Durand afirma que a métrica, ou seja, o modo de medir a distância, por intermédio da escala cartográfica remete a uma medida do terreno, do espaço físico, da medida geométrica, expressa em $\mathrm{Km}$ e que frente à configuração espacial contemporânea não pode ser a única maneira de medir esse espaço.

[...] relação variável entre distância, custo e tempo, que revestem os lugares de toda a sua importância em um mundo ao mesmo tempo ubíquo, topológico (as redes materiais de troca) e topográfico (as distâncias euclidianas da terra), isto é, um mundo multimétrico. (DURAND, 2006, p.437).

Segundo a autora, herança da história da cartografia, que demonstra que a partir de um princípio territorial um mapa sempre foi a representação do espaço, pois por muito tempo os mapas serviram para legitimar fronteiras, construir territórios, e assim estruturavam o mundo. Nesse contexto, o princípio territorial constituiu a base fundamental dos mapas. E "o mapa topográfico passou a ser imediatamente 
associado à Geografia" (DURAND, 2006, p.433). Nesse panorama o mapa, sob a métrica euclidiana, estava a contento.

No entanto, há que se considerar que hoje, frente ao processo de globalização em que se está imerso, não é mais possível perpetuar essa relação direta. Só o princípio territorial, isoladamente, não dá conta de explicar as relações societais espacializadas. Outras relações estão presentes e devem ser consideradas no momento de representar o espaço geográfico. Não seria o caso de se pensar na necessidade de representar as relações distância-custo ou distância-tempo? Denise Pumain afirma que as distâncias comumente são medidas em unidades de tamanho que expressam a distância entre dois pontos e cuja unidade é o metro. Todavia, por decisões dos agentes envolvidos estão às vezes mais afetadas por considerações econômicas, citando, por exemplo, que a distância-custo se mede por meio do preço do transporte. A distância-tempo, segundo a duração necessária para o percurso desejado, portanto não são iguais entre si. Sendo assim não podem ser mensuradas da mesma maneira em quilômetros (Cf. Pumain, 2006, p. 02). Esses dados fazem toda a diferença para uma corporação transnacional no momento de decidir onde se instalar ou para onde se deslocar, é uma questão de acessibilidade ${ }^{13}$ e da busca pelo lucro. É uma informação relevante para as pessoas, inclusive, tanto nas questões de economia de tempo como de dinheiro.

Retomando-se o processo de globalização e suas manifestações, entende-se que o local é parte do global e que no atual processo de globalização o local confunde-se com o global, pois forças externas atuam, impondo-se a ele. Ratifica-se que durante as aulas de Geografia deve ficar claro para os alunos a interdependência nas relações internacionais no contexto atual. Para evidenciar a importância de algumas dessas interdependências, pretende-se trabalhar com 0 tema "Importações e Exportações" para a construção de um dos mapas em sala de aula, o que permitiria a visualização, de certa forma, do sistema-mundo. Após a construção do mapa haveria uma aula expositiva que permitisse aos alunos

\footnotetext{
13 "Em Geografia, a acessibilidade de um lugar se define em geral como a maior ou menor facilidade com a qual esse lugar pode ser alcançado a partir de um ou vários lugares, por um ou vários indivíduos suscetíveis de movimentar-se com a ajuda de todos ou alguns dos meios de transporte existentes. [...] Não se limita somente ao movimento de indivíduos de um lugar a outro. Por exemplo, em uma rede de telecomunicações, a acessibilidade a um nó está ligada com a possibilidade e a qualidade da aquisição, inclusive da troca de informações, a partir de um ou de vários outros nós". (CHAPELON, 2006).
} 
entender como ocorrem as relações do Brasil num contexto de globalização e a importância da balança externa brasileira.

É necessário pensar, então, nas diferentes escalas de representação dos fenômenos e será preciso tornar evidente, nas aulas de Geografia, influências do global no local e a influência de cidades globais para os alunos. Marie-Françoise Durand fala de cidades globais, que "são lugares centrais que organizam a arquitetura das redes mundiais" (DURAND, 2006, p.437) e de fluxos informacionais, de mercadorias e de pessoas, nas discussões sobre as novas configurações espaciais. Embora o conceito de espaço geográfico de Milton Santos é o que norteie todo este trabalho, e o autor não use o termo cidades globais, julga-se conveniente trazer alguns autores citados por Mônica Carvalho para ampliar as considerações a respeito:

\begin{abstract}
Seria, portanto, global a cidade que se configurasse como nó ou ponto nodal entre a economia nacional e o mercado mundial, congregando em seu território um grande número das principais empresas transnacionais; cujas atividades econômicas se concentrassem no setor de serviços especializados e de alta tecnologia, em detrimento das atividades industriais; quando, por conseqüência, o mercado de trabalho fosse polarizado gerando novas desigualdades sociais e uma forma de segregação urbana dualizada (LEVY, 1997; VÉRAS, 1997; MARQUES e TORRES, 1997 apud CARVALHO, 2000, p.72 ).
\end{abstract}

Num mundo multimétrico, os fluxos e as redes geográficas devem estar presentes nas representações do espaço que configuram essas cidades. Sendo assim, o poder analógico do mapa como apresentado até agora nos livros didáticos, entendendo-se que nele se encontraria parte da lógica do seu referente, e uma vez que se admite que o espaço geográfico não seja mais, apenas geométrico, baseado na métrica euclidiana, o potencial dessa analogia encontra limites sérios. Michel Lussault afirma:

[...] pelos mapas que colocam em cena uma metrologia, um pensamento da medida e da posição dos objetos espaciais sobre uma extensão [...] quer se chegar a estabilizar o espaço [...] Assim, o meio gráfico, por um golpe de força representacional, é um operador eficaz do 'apagamento' da característica insubstituível (grifo do autor) de cada espaço de ações. O espaço fixado pela iconografia torna-se de maneira ficcional, duplamente substituível: substituível por ele mesmo [...] pois doravante a figuração deixa crer que sua situação é quase-estável no tempo. Substituível por outros espaços, já que, por analogia gráfica, o espaço figurado torna-se estritamente comparável a um espaço. (LUSSAULT, apud FONSECA, 2004, p.210).

E com Marie-Françoise Durand afirma-se que diante das mudanças apresentadas a cartografia enfrenta um problema: dar conta de novas 
representações compatíveis com o espaço que precisa representar (DURAND, 2006, p.438).

Jacques Lévy chega a falar em crise do mapa mediante esse contexto e apresenta o seguinte quadro:

Quadro 2: Representações da crise do mapa

'Representações' da 'crise do mapa'

1. Função ideológica associada à Geopolítica e aos poderes hegemônicos

2. Dificuldades de domínio para informações reduzidas

3. Concorrência de outras mídias de alto teor tecnológico

4. Incompatibilidade do espaço euclidiano (a submersão das cidades e das redes)

Adaptado de LÉVY, 1999, apud FONSECA, 2004, p. 224.

Considera-se necessário destacar o que o autor chama de incompatibilidade do espaço euclidiano (a submersão das cidades e das redes). Colabora para esta discussão, Fernanda Padovesi Fonseca, ao afirmar que "vários fenômenos são muito mal representados no mapa" (FONSECA, 2007, p. 93), e entre eles estão as cidades e as redes geográficas. E neste caso seria a métrica euclidiana incompatível com as novas configurações espaciais, por este motivo o resultado das representações não é satisfatório. Ainda segundo a autora, como seria possível, apenas sob a métrica euclidiana, representar as redes geográficas que se espacializam e que dão forma e conteúdo à cidade de São Paulo? A questão central é que a cidade aparece comumente nos mapas representada apenas por pequenos pontos. Esse fato colaboraria para a crise do mapa. E esta observação é válida para todas as grandes cidades representadas em mapas-múndi.

Observe-se então o que coloca Patrick Poncet com relação à correta utilização do mapa para o espaço geográfico contemporâneo:

A cartografia de um 'mundo mundializado' enfrenta dois desafios: como 'mundializar o mapa', isto é representar a espacialidade 'glocal' da mundialização, articulando corretamente divisão e unidade? Como achatar o mundo, ou seja, representar a sua geometria não euclidiana, cuja expressão é particularmente forte nos fenômenos mundializados, que suscita a questão dos limites da cartografia e das pertinências do seu uso na geografia? (PONCET, 2011, p.03 ). 
Ainda segundo Jacques Lévy e Michel Lussault o espaço se caracteriza por três atributos fundamentais: a escala, a métrica e a substância. Definir o tamanho do espaço (por meio da escala), decidir qual a melhor maneira de demonstrar como se mediu esse espaço (por meio da métrica) e evidenciar a dimensão não espacial dos objetos espaciais (substância) num mapa, é uma decisão complexa, mas necessária. Como recurso significativo no ensino, o mapa não deveria ser capaz de mostrar a complexidade visível da realidade, já nas séries iniciais do ciclo II?

Colocação significativa sobre o que é o mapa vem do trabalho desses autores ao afirmar que o mapa é um objeto híbrido. Além de ser uma representação do espaço fixo na matéria, o mapa, em si mesmo, é um espaço. Na “interespacialidade via mapa e linguagens com outros níveis escalares, pode nutrir outras práticas de espaço (um deslocamento, um projeto urbano, um evento, a produção de novos documentos gráficos) e vários imaginários" (LÉVY, LUSSAULT, 2003, p. 325-333).

A partir dessas constatações, e embora seja necessário pensar atividades que levem à interpretação e representação do espaço geográfico contemporâneo em sala de aula, nesta pesquisa serão aplicados exercícios de construção de mapas com um recorte espacial sobre o território brasileiro e com uma métrica euclidiana apenas. Esta escolha ocorreu unicamente pelo fato de este recorte espacial ser um conteúdo presente atualmente no currículo da $6^{\mathbf{a}^{14}}$ série do ensino fundamental, o que facilitaria a sua inserção nas atividades cotidianas do ano letivo.

Frente ao exposto não haveria então uma necessidade urgente para a Geografia escolar, que as discussões acadêmicas abordassem de maneira renovada os trabalhos com mapas, para que houvesse coerência entre o espaço geográfico real e aquele que é representado pela cartografia atualmente utilizada e que está presente nos atlas geográficos e livros didáticos?

Dando continuidade às reflexões sobre os elementos do mapa e com a intenção de demonstrar que o mapa é fruto de muitas escolhas, como por exemplo, qual métrica utilizar, será preciso ater o olhar por um breve momento sobre outro componente do mapa, a Projeção.

É sabido que toda a projeção resulta numa deformação conhecida do espaço representado e, portanto, controlável. São escolhas que necessitam ser feitas para evidenciar tal ou qual objeto. Patrick Poncet afirma que:

\footnotetext{
${ }^{14}$ Hoje a legislação denomina $7^{\circ}$ ano e não mais 6ạ série.
} 
[...] o espaço curvo constituído da superfície de uma esfera não pode ser aplanado sem ser deformado de uma parte e deturpado em outra. A técnica de projeção, [...] permite estabelecer uma relação de equivalência entre as coordenadas geográficas de um lugar no globo e aqueles em uma grade sobre um fundo de mapa (PONCET, 2011, p.02).

$E$, diferentemente da questão da métrica euclidiana que é aceita como a única correta, diversas projeções são admitidas! Porque não aceitar que um engessamento nessa maneira de medir os espaços seria permanecer estagnado numa teoria que não explica mais a realidade vivida? Não seria mais conveniente admitir que esta métrica, exclusiva, e isoladamente, e a rejeição de outras possibilidades, não seria compatível com uma Geografia social, vivida, e que precisa ser evidenciada pelos mapas que pretendem representá-la?

Neste sentido, ainda, considere-se então a escala cartográfica que deve ser pensada para a redução ideal do terreno a ser representado no mapa, para que os fenômenos geográficos possam ser visíveis e analisáveis.

Dentro das possibilidades para a representação do espaço geográfico aparece 0 trabalho de Colette Cauvin sobre anamorfoses ${ }^{15}$. Se, e agora é necessário admitir que as anamorfoses sejam recursos possíveis para a representação dos espaços, o que se aceita neste trabalho como verdadeiro, trabalha-se com uma anamorfose sobre a população absoluta, o referencial não será mais o terreno, mas a população. Entende-se, junto com a autora, que utilizar as anamorfoses em sala de aula de Geografia é uma possibilidade a mais para a representação do espaço geográfico contemporâneo. Segundo Jacques Lévy, já mencionado, tem-se que representar a substância, dimensão não espacial dos objetos espaciais (substância) num mapa (LÉVY, LUSSAULT, 2003, p. 325-333), e as anamorfoses dariam conta disso.

Nesse caso não é sobre o terreno que se pretende discorrer com a anamorfose, é sobre a população. O objetivo é mostrar visualmente como foi alterado o fundo territorial pelo peso populacional. $O$ ideal não seria então trabalhar com dois mapas? Um com fundo territorial de referência e o outro com a informação

\footnotetext{
${ }^{15}$ Colette Cauvin discorre sobre as anamorfoses como uma transformação cartográfica espacial, já que é a mudança, por meio de uma operação matemática (ou eventualmente gráfica), de uma forma do mapa a outra forma do mesmo espaço. (CAUVIN, Colette, Transformações cartográficas espaciais e anamorfoses). In: DIAS, Maria Helena (Coord.) Os mapas em Portugal: da tradição aos novos rumos da cartografia. Lisboa: Cosmos, 1995. P. 267-310.
} 
populacional, a anamorfose? Portanto, mapas complementares? O que se pretende fazer nesta pesquisa. Ao mesmo tempo em que se desenvolvem no aluno as competências e habilidades para trabalhar com várias métricas, ele poderia se familiarizar com a correlação e a análise.

Sendo assim, as anamorfoses também seriam possibilidades de representação do espaço geográfico contemporâneo assim como as diferentes projeções, uma vez que possuem deformações controláveis e facilitariam a apreensão visual do fenômeno que se desejar ressaltar.

Nesta pesquisa, o objetivo não é abolir os mapas baseados na métrica euclidiana. Entende-se que em muitos casos de análise espacial eles são extremamente necessários. Em outras, ele deve ser complementar a outro mapa com uma métrica diferente da sua. Tem-se como princípio que esses mapas "tradicionais" devem estar em sala de aula, mas, os mapas temáticos, as anamorfoses, e os mapas de redes e fluxos também.

A ideia é que a partir do material cartográfico que hoje está disponível no ensino fundamental e médio, e ao aprenderem a gramática da representação gráfica, os alunos percebam as dificuldades de representação das redes geográficas, por exemplo, e procurem também uma maneira de representá-las. Quem sabe não poderia vir desse público sugestões para uma cartografia geográfica? Caberia então às instituições de nível superior, por intermédio do desenvolvimento de pesquisas, e a partir do que se observa em sala de aula, elaborar teorias que explicassem o que se produziu ali.

Entende-se que o papel do professor de Geografia, neste caso, é fundamental, pois caberá a ele levar material diversificado para as aulas, a fim de que os alunos se habituem também a outras métricas, a diversas projeções. Por exemplo, no caso da anamorfose o que importa é que ela funcione como linguagem visual na transmissão da informação populacional. Após a visualização do fenômeno, se faria uma correlação com um mapa de referência, de fundo euclidiano, para a análise que se desejasse. Não seria mais enriquecedor para o ensino e para a aprendizagem em Geografia que os alunos tivessem acesso a várias possibilidades de representação do espaço?

O que se pretende evidenciar é a necessidade de rever, dentro da Geografia Humana, do ensino de Geografia em especial, apenas a utilização de mapas baseados na métrica territorial (Cf. Durand, 2006, p. 437) e a necessidade, de 
utilização e construção, de mapas que se apresentem a contento segundo a gramática da representação gráfica conforme a Semiologia gráfica pelo menos, que estará evidente por intermédio do que Jacques Lévy chamou de Simbólico.

\subsection{Uma cartografia desejável para o ensino}

Segundo Fernanda Padovesi Fonseca, a história da cartografia mostra que sua evolução ocorreu segundo um duplo movimento: "especialização técnica [...] e formalização geométrica de referencial geodésico configurando uma cartografia matemática" (FONSECA, 2007, p. 90). No entanto, a autora alerta para a necessidade de o mapa ser aperfeiçoado naquilo que ele pode contribuir de diferente e refere-se então às práticas cartográficas em Geografia. Afirma que essas práticas possuem hoje um potencial de renovação e traz a linguagem dos mapas como facilitadora desse processo: "o mapa pode e deve ser entendido como uma linguagem" (FONSECA, 2007, p.92).

Partindo do pressuposto que a linguagem dos mapas poderia impulsionar o desejado progresso da cartografia com a finalidade de representar o espaço geográfico contemporâneo, concorda-se com Antônio Carlos Castrogiovanni, que os mapas devem "ser vistos como uma possibilidade admirável de comunicação" (CASTROGIOVANNI, 1995, p.151).

Nesse sentido, segundo Jacques Bertin é preciso compreender, que a construção gráfica, se observada a gramática da representação gráfica, não está presa à teoria da comunicação, pois não permite várias interpretações, tal como um texto ou um quadro. Portanto, o desejável é que os alunos entendam essas regras. Ao utilizá-las eles tem que ter em mente que ela só permitirá uma e apenas uma interpretação (Cf. Bertin, 1980, p. 161) das informações no mapa. Assim, vê-se claramente a necessidade de conhecer a linguagem dos mapas para não incorrer em erros.

Num enfoque mais abrangente, e para além da sala de aula, Brian Harley afirma que os mapas são uma linguagem gráfica que merecem e necessitam ser decodificados uma vez que "estão impregnados de intenções e consequências" (HARLEY, 2005, p. 62). O que Harley apresenta é o processo de construção do mapa. Os contextos do cartógrafo, da sociedade, e o contexto de outros mapas. Todos devem ser considerados, pois eles resultarão no produto final, o mapa, que será utilizado. Nesse sentido o que se poderia esperar dos produtos finais, mapas 
que chegam à sala de aula, inclusive, e que foram construídos sob as novas facilidades das tecnologias? Teriam sido produzidos a contento sob as regras da gramática da representação gráfica? Seriam portadores de verdades ou inverdades? O que se propõem comunicar é realmente o que seria possível ver ou ler nesse mapa que chega até a aula de Geografia?

Uma preocupação emerge ao se entender que 0 acesso às tecnologias permite a distribuição de muitos mapas, no entanto eles teriam sido construídos com qual objetivo e em qual contexto social? Eles seriam a representação de uma cartografia geográfica? Haveria a correlação entre linguagens? E o cartógrafo, qual seria seu contexto no momento de construir o mapa que estará na sala de aula? Parte do contexto do cartógrafo é sem dúvida o que ele domina sobre a linguagem dos mapas e a utilização das tecnologias.

O domínio das tecnologias, no entanto, não significa o domínio da linguagem dos mapas. Mesmo ao utilizar os softwares que possibilitam um trabalho mais rápido e sofisticado na produção de mapas não se pode utilizá-los em aulas sem antes realizar uma avaliação crítica desse material (Cf. Martinelli, 2008, p.11).

Hoje, é comum ouvir sobre o desenvolvimento de habilidades e competências na educação básica (ensino fundamental e médio) ${ }^{16}$.

Observe-se:

Competências são as modalidades estruturais da inteligência, ou melhor, ações e operações que utilizamos para estabelecer relações com e entre objetos, situações, fenômenos e pessoas que desejamos conhecer. As habilidades decorrem das competências adquiridas e referem-se ao plano imediato do "saber fazer". Por meio das ações e operações, as habilidades aperfeiçoam-se e articulam-se, possibilitando nova reorganização das competências. (BRASIL, 2010).

Sendo assim, entende-se que o mapa como uma linguagem é essencial no processo de ensino e aprendizagem tanto para o desenvolvimento de competências como de habilidades ${ }^{17}$. Em se tratando de alunos do ensino fundamental e médio

\footnotetext{
${ }^{16}$ O ENEM (Exame Nacional do Ensino Médio) apresenta uma matriz de referência que detalha cinco competências e vinte e uma habilidades necessárias e que, portanto serão avaliadas no momento do exame. Em anexo ao documento são apresentados os Objetos de conhecimento associados às Matrizes de Referência, onde se destaca para este trabalho, dentro das Ciências humanas e suas tecnologias, área onde aparece a Geografia, a Representação espacial (BRASIL, 2010).
}

\footnotetext{
${ }^{17}$ Há na matriz de referência das Ciências Humanas e suas Tecnologias, a competência de área 2: H2 compreender as transformações dos espaços geográficos como produto das relações socioeconômicas e culturais de poder. Na competência de área 6: compreender a sociedade e a
} 
principalmente, que têm acesso às tecnologias da informação, com utilização de computadores e softwares grátis nas próprias escolas, e muitos dos alunos, em casa, inclusive, não seria conveniente e necessário que eles aprendessem as regras da gramática da representação gráfica? É preciso lembrar que a gramática da representação gráfica estrutura a linguagem dos mapas. Neste caso haveria a possibilidade de desenvolver competências e habilidades na leitura e produção de mapas que representariam o espaço geográfico a contento.

Janine Gisele Le Sann pode colaborar para o entendimento do que é pretendido aqui, ou seja, num contexto de uma educação necessária para o século $\mathrm{XXI}$, o ideal é que o professor trabalhe tendo em mente uma proposta metodológica centrada no aluno. O aluno deve participar ativamente da construção de seu conhecimento. Ela afirma, com relação à utilização de computadores no ensino, que o computador deve estar centrado na aprendizagem do aluno, e não na reprodução dos métodos tradicionais de ensino. Chama a atenção, inclusive, para o fato de que o computador deve ser visto apenas como um instrumento, que, assim como outros, apresenta possibilidades e problemas para e no ensino, conforme o uso que se pretender dele. Hoje, na busca de uma educação adequada para o século XXI, o aluno deve ser o construtor de seu aprendizado, e poderá utilizar o computador para tal. Especificamente em relação aos trabalhos com mapas, o aluno, mesmo utilizando os computadores, ou o método tradicional de desenho manual, que foi adotado nesta pesquisa, deve saber interagir com os mapas. Ao reverem-se os objetivos de ensino é possível desenvolver habilidades e competências, inclusive, sem altos custos e sem tecnologias sofisticadas. A mesma autora apresenta um trabalho onde 0 aluno deve ser o construtor de seus conhecimentos geocartográficos por intermédio dos trabalhos com mapas onde o pretendido é ensinar o aluno a construir conhecimento (LE SANN, 1997a, p.25-30. 1997b, p.31-34, ).

A proposta da autora embasa igualmente o que é proposto neste trabalho. Que os alunos conheçam a gramática da representação gráfica para poder ler, construir e interpretar mapas no ensino de Geografia. E também que as construções dos mapas, sob essa gramática, em sala de aula, necessitam apenas de lápis, papel, borracha, lápis de cor, e cópias Xerox de fundos de mapas. 
O que se destaca, e que se entende, potencializa o trabalho de leitura e construção de mapas em aulas de Geografia é que desde a década de 1960 com o trabalho desenvolvido por Jacques Bertin sobre a Semiologia gráfica, e da contribuição teórica de Christopher Board (1975) ${ }^{18}$ já era possível ter acesso a todo um arsenal teórico e metodológico passível de ser utilizado na Geografia por meio da cartografia como linguagem, principalmente para o ensino.

No entanto, é preciso lembrar que, no cenário brasileiro, essas propostas não foram utilizadas a contento para o ensino, nem pelos geógrafos e nem pelos professores de Geografia. Uma afirmação ainda mais forte nessa direção é que as práticas cartográficas não estiveram presentes nas atividades dos pesquisadores e demais praticantes da Geografia Humana, o que resultou num afastamento da cartografia do processo de renovação da Geografia. Os geógrafos deixaram-se envolver pelas afirmações de que as "representações" seriam apenas auxiliares nas propostas de renovação que surgiram. "Apenas alguns compartimentos especializados dos cursos de Geografia discutiram as representações e a linguagem" (FONSECA, 2007, p.86-87).

Vê-se então a necessidade de retomar as discussões sobre as possibilidades na cartografia para uma Geografia que tem que dar conta de representar o espaço geográfico como componente da sociedade, ou seja, para uma cartografia geográfica.

Sendo assim, uma Geografia que busca a renovação, não deveria também direcionar o olhar para a cartografia escolar? Aquela que acontece na sala de aula?

Trata-se nesta oportunidade sobre uma cartografia escolar ideal para trabalhar em sala de aula na disciplina de Geografia, e consciente de que o ideal nem sempre é possível de ser colocado em prática, pois, está no plano das ideias apenas. Mas, mediante os trabalhos já citados com base no ensino do mapa e da gramática da representação gráfica de Jacques Bertin, poder-se-ia afirmar que o ensino de Geografia, que usa a cartografia é uma possibilidade real.

Entre os autores brasileiros de importância para a cartografia escolar estão Lívia de Oliveira, Tomoko lyda Paganelli, Janine Gisele Le Sann, Maria Elena Ramos Simielli, Rosângela Doin de Almeida, Antônio Carlos Castrogiovanni, Elza

18 BOARD, Christopher. Os mapas como modelos. In CHORLEY, R. J. e HAGGET, P. (org.). Modelos físicos e de informação em Geografia. Rio de Janeiro: Livros técnicos e científicos. São Paulo: EDUSP, 1975. p. 139-184. 
Yasuko Passini, e Marcello Martinelli ${ }^{19}$ que demonstram a importância dada aos mapas no ensino. Rosângela Doin de Almeida ${ }^{20}$, inclusive, organiza um trabalho de produções acadêmicas de alguns desses autores, nos quais se observa a preocupação com atividades cartográficas que levem ao desenvolvimento cognitivo dos alunos. E estes são apenas alguns trabalhos brasileiros sobre cartografia escolar, mas de fundamental importância para esta discussão, portanto, em alguma medida colaboram com a pesquisa aqui realizada. Todavia, em todos eles são observadas algumas lacunas com relação à discussão de renovação.

O que se observa é que mesmo o termo espaço geográfico aparecendo em alguns desses trabalhos, não fica claro como os autores entendem esse espaço. Apenas supõe-se que para eles o espaço é um espaço absoluto, pois mensurável pela métrica euclidiana, inclusive diante da inexistência nos trabalhos mais recentes, do período no qual a Geografia já estava em processo de renovação, de discussões sobre outras métricas. As discussões feitas pelos autores giram em torno da representação do espaço vivido, da lateralidade, de referenciais de frente/atrás, das representações projetivas e euclidianas (Cf. Almeida, 2008, p.148). Neste caso, a métrica euclidiana é suficiente em si para tal, mas, ao se pensar num espaço relacional, apenas essa métrica, a euclidiana, não dá conta de mensurá-lo (FONSECA, 2004, p. 225-241). A análise destes trabalhos permite afirmar que com relação à representação do espaço absoluto, não há mais o que se discutir, pois a contribuição destes autores abrange a totalidade de atividades e exercícios que permitem a espacialização de objetos analisados sob uma distância euclidiana. São trabalhos necessários e referenciais teóricos para trabalhar a cartografia na representação do espaço absoluto em sala de aula desde as séries iniciais da escola básica.

Nesta pesquisa, no entanto, a proposta de renovação é uma preocupação constante, uma vez que se entende que a cartografia comumente presente em sala de aula, não dá conta de representar o espaço geográfico contemporâneo. Entendese que a cartografia enquanto linguagem seria essencial no ensino de Geografia. Assim, ocorre aqui uma discussão teórica sobre o tema. Na parte prática pretendese permanecer na aplicação da gramática da representação gráfica para fenômenos

\footnotetext{
${ }^{19}$ Marcello Martinelli tem livros que tratam da aplicação prática da gramática da representação gráfica direcionados para alunos de graduação e pós-graduação.

${ }^{20}$ ALMEIDA, Rosângela Doin (org.) Cartografia escolar. São Paulo: Contexto, 2008.
} 
espacializados, via cartografia temática apenas, uma vez que se trabalhará unicamente com alunos da escola básica do ciclo II em diante.

Faz-se necessário então analisar a cartografia presente nas salas de aula de Geografia, para saber qual é o universo cartográfico dos alunos. Observa-se que a cartografia utilizada é a expressão de uma Geografia que ainda não se reestruturou plenamente frente ao movimento de renovação no qual ainda está imersa (OLIVA, 2002, p. 34-49). No entanto, já a partir da crise de 1970, que marca uma ruptura com a Geografia física, iniciou-se na Geografia francesa "a construção de um trabalho epistemológico de definição de uma verdadeira ciência da dimensão espacial do social" (DURAND, 2006, p.435). E é dos trabalhos dos autores franceses que surgem novos referenciais para uma cartografia que represente o espaço geográfico como dimensão da sociedade e que deveria estar em sala de aula. Oportunamente se apresentarão os trabalhos desses autores os quais poderiam colaborar para o ensino de Geografia sob a ótica de uma renovação.

No entanto Jaime Tadeu Oliva aponta uma dificuldade de renovação da Geografia para o ensino médio brasileiro.

\begin{abstract}
[...] pensando numa Geografia renovada, que contribua para a construção de uma educação entendida como um valor social, agregador e civilizador, diríamos que os caminhos desejáveis para a Geografia renovada e seu ensino deveriam estar livres do pavor à teoria e deixar-se inundar pela imaginação teórica, pensando nos conceitos como ferramentas e não a realidade e a verdade [...] Refletir a respeito do espaço geográfico e apostar no seu potencial explicativo da realidade, levaria ao reconhecimento do valor educacional da Geografia, pressionando para eliminar o atraso desnecessário na evolução de nossa disciplina. (OLIVA, 2002, p. 49)
\end{abstract}

Levar para a sala de aula de Geografia mapas que funcionem como linguagem visual, não seria apostar no potencial explicativo da realidade? $O$ aluno, detentor do conhecimento da gramática da representação gráfica, que estruturam a linguagem dos mapas poderia ver na disciplina escolar Geografia o seu valor educacional.

Mas, ao verificar-se que a Geografia escolar chega até as salas de aula principalmente por livros didáticos, é preciso então, observar alguns exemplos desses livros, que foram por muito tempo os únicos materiais, e com forte presença, na sala de aula de Geografia nas escolas (SOUZA, 2002, p.15). O livro didático utilizado para apresentar e explicar o espaço geográfico está repleto de mapas, inclusive temáticos, numa tentativa de utilização das regras da gramática da 
representação gráfica, mas que não observam criteriosamente as orientações oferecidas por Jacques Bertin.

Os únicos exercícios propostos no material didático analisado são amparados pelos trabalhos dos autores que pensam o espaço sob a métrica euclidiana apenas. Nesse material há comumente atividades de construção de croquis (em diferentes escalas), mapas mentais (e aqui poderia haver uma possibilidade para a renovação), trabalhos com escala cartográfica, etc., mas todos retratando um espaço absoluto apenas. Não se observa discussão de diferentes espaços em atividades concretas para os alunos realizarem, nem mesmo no ensino médio.

Jaime Tadeu Oliva trata dessa realidade como parte de um 'retardo desnecessário' para o ensino de Geografia (OLIVA, 2002, p.34).

No entanto, também é preciso dizer que há materiais bastante produtivos do ponto de vista da aplicação da gramática da representação gráfica. Rosângela Doin de Almeida demonstra uma preocupação na proposta de atividades cartográficas nas quais o aluno deve praticar. No referido material há anamorfoses, como possiblidades de representações de fenômenos espacializados, por exemplo.

Todavia, mesmo num material no qual se observou criteriosamente a gramática da representação gráfica, foram poucas as vezes em que se encontrou uma construção que pudesse representar os fluxos ou as redes geográficas.

$\mathrm{Na}$ busca de mapas que possibilitem o desenvolvimento cognitivo dos alunos trabalhos de autores franceses podem colaborar. Embora não sejam direcionados especificamente para os alunos da escola básica, o trabalho de Colette Cauvin apresenta as anamorfoses, que em muitos casos trazem para o fundo do mapa representações espaciais que podem ser consideradas mais cognitivas, como aquela das densidades populacionais, por exemplo. Esta poderia ser uma possibilidade para a Geografia escolar desde as séries iniciais do ciclo II. Sugere-se, inclusive, que os alunos possam trabalhar com dois mapas ao mesmo tempo. 0 objetivo é que possam comparar os mapas, uma vez que a imagem pode causar estranheza a eles pelo fato de não estar presa à métrica territorial, pois o referencial é outro, é o populacional. Evidencia-se também a necessidade de mapas dinâmicos, de fluxos, uma vez que cabe à Geografia explicitar os fluxos materiais e imateriais na contemporaneidade a contento.

A figura 01 serve de apoio à afirmação sobre as qualidades da anamorfose e do mapa territorial. 
Empiricamente, nas atividades cotidianas de sala de aula, verifica-se que para a apreensão de uma criança, o que tem mais, é maior, e é o fundo do mapa que varia no caso da anamorfose. Sendo assim a variação do tamanho do fundo do mapa, que é visual, pode mostrar-se mais cognitiva. Como se verifica no caso da aplicação das variáveis visuais da imagem onde se encaixa a variável visual tamanho, esta variável, se aplicada ao fundo do mapa, seria significativa para o ensino e a aprendizagem na construção das anamorfoses.

Utilizando o mesmo exemplo do mapa territorial, tem-se que no ensino de Geografia, comumente se utiliza o mapa de contornos territoriais para, por exemplo, permitir aos alunos verem o tamanho dos territórios de cada país.

No entanto há que se considerar que também existe a questão de que a escala cartográfica pode não fazer muito sentido para os alunos, o que se observou empiricamente durante as aulas expositivas na prática de ensino cotidiana.

Se, o espaço físico, territorial, pode ser demonstrado pela variação do tamanho do fundo do mapa, mesmo sem os alunos terem o devido conhecimento das reduções da escala, mas que eles acabam entendendo por associação de tamanhos variados no mapa "tradicional", não seria o caso de se alterar também o fundo de mapa para demonstrar o tamanho de outros fenômenos sociais que ocorrem nesse espaço territorial?

Se sim, a partir das discussões levantadas por meio da leitura cartográfica, poder-se-ia levar os alunos à interpretação dos conceitos de populoso e povoado mais facilmente.

O fenômeno não seria mais visível se a sua apreensão fosse visual e imediata, por meio da comparação da anamorfose com o mapa territorial de referência?

Sendo assim as possibilidades para o ensino aparecem quando se entende que existe um processo de renovação em curso na Geografia, mas a cartografia escolar permaneceu distante das discussões nesse sentido. Admitindo-se certo distanciamento, já seria possível se pensar na necessidade de superá-1021.

\footnotetext{
${ }^{21}$ Encontra-se apoio em algumas ideias sobre o mapa que podem chegar ao ensino de Geografia no Brasil, além das do trabalho como os de Colette Cauvin (1995) que fala sobre as anamorfoses, já citada, como recurso para a Geografia escolar. Também, mais recentemente, temos o Atlas da Mundialização de Durand et al. (2009), já voltado ao público escolar, com o objetivo de compreender o espaço mundial contemporâneo, onde se observa uma contribuição significativa para o ensino de uma Geografia que se renova e para a produção de mapas que respeitem os princípios da
} 


\section{Mapa territorial de referência e anamorfose}

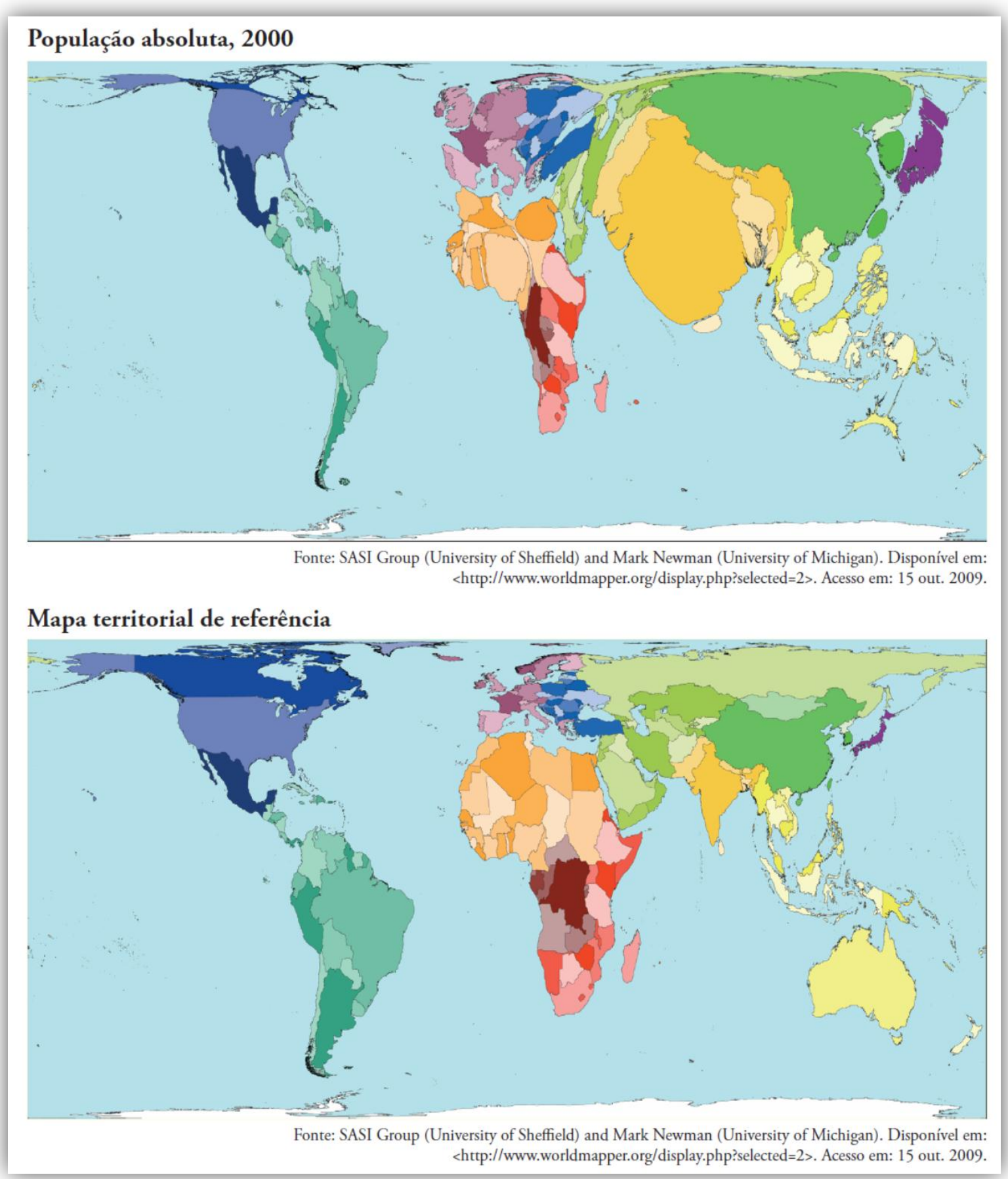

Figura 1: Anamorfose e mapa territorial de referência. Apud SP (Estado)-SEE. Caderno do aluno Geografia - ensino médio - 1ํ ano, São Paulo: SEE, 2009, v. 1, p. 16.

Semiologia gráfica, que permitiriam, a princípio, representar o espaço geográfico em sua complexidade. 
Com relação às contribuições para tornar mais accessíveis os mapas para e no ensino Maria Elena Ramos Simielli coopera com o que se denomina aqui "liberdade" cartográfica quando trata de mapas mentais:

O mapa mental permite observar se o aluno tem uma percepção efetiva da
ocorrência de um fenômeno no espaço e condições de fazer a sua
transposição para o papel. Ele vai trabalhar com todos os elementos
essenciais que a cartografia postula no tocante a sua forma de expressão ---
a linguagem gráfica. (SIMIELLI, 2002, p.107).

Nesse contexto, ela salienta que ao se trabalhar com a leitura e construção de mapas no ensino, tem-se "aluno leitor crítico ou mapeador consciente [...] [e que] eliminam a possibilidade do aluno copiador de mapas" (SIMIELLI, 2002, p.99).

Ao trabalhar com a produção de mapas mentais em sala de aula do ensino fundamental pode-se observar empiricamente que cada aluno representa de maneira diferente a sua espacialidade. Alunos que são vizinhos, inclusive, fazem representações muitos diferentes do seu cotidiano, embora ele seja vivido, em grande parte, no mesmo espaço absoluto.

É importante que se coloque, ainda com a mesma autora, que os trabalhos com escala (SIMIELLI, 2002, p.100) devem continuar no ensino de Geografia, já que a escala é a representação da redução do espaço físico, absoluto. Mas então, seguindo suas orientações, não seria conveniente pensar numa certa liberdade de construção cartográfica em prol do processo de ensino e aprendizagem já que o trabalho com mapas mentais também é significativo no ensino? Portanto, a solução de estrutura do mapa que está presente neste trabalho se mostraria pertinente, uma vez que coloca a escala como o grau de redução do representado e métrica como as diversas possibilidades de medida entre os objetos geográficos. Nos mapas mentais, em muitos casos, as métricas são bastante pessoais e cognitivas dos alunos, mostrando como o indivíduo percebe e atua nas distâncias cotidianas.

Marcello Martinelli ${ }^{22}$ faz uma ressalva com relação à suposta liberdade de escolha para a representação, quando se trabalha com cartografia temática e com as regras da gramática da representação gráfica: "A "liberdade" estaria atrelada à observação dos componentes gramaticais da representação gráfica”. O que é um pressuposto nesta pesquisa, uma vez que é uma constante a afirmação do

\footnotetext{
${ }^{22}$ Informação de aula de 09/04/2010 no Departamento de Geografia da FFLCH.
} 
conhecimento, tanto pelo professor como pelo aluno, das regras da gramática da representação gráfica.

Com o trabalho de Jacques Bertin e Roberto Gimeno (BERTIN e GIMENO, 1982, GIMENO, 1991) é possível compreender os processos de construção cartográficos desejáveis para o ensino de Geografia. Esses autores dizem que normalmente os exercícios cartográficos iniciam-se com a copiagem de mapas do livro didático ou do atlas geográfico escolar. No entanto, os professores questionavam esse procedimento, e afirmam que a criança não se vê motivada a fazer, a participar dessa atividade, pois não foi preparada para isso (Cf. Bertin e Gimeno, 1982, p. 38-39).

Segundo os autores, os métodos gráficos são significativos para o processo de ensino e aprendizagem. No entanto, e ainda diante das observações cotidianas no exercício da profissão docente, é possível verificar que as situações didáticas e mesmo os conteúdos norteadores das atividades cotidianas, podem e devem ser adequadas às necessidades surgidas no decorrer de uma aula.

Assim, concorda-se com Jacques Bertin e Roberto Gimeno quando afirmam que o professor deve orientar e direcionar, os trabalhos cartográficos. Corrobora para esta afirmação Maria Elena Ramos Simielli quando diz:

Eventualmente o mapa pode ser copiado e essa situação se apresenta quando o professor tem um objetivo bem definido e o deixa explicitado, mas será sempre uma situação esporádica e não a regra nas aulas de Geografia (SIMIELLI, 2002, p.108).

Claro que, em se tratando de uma proposta de renovação, as atividades cartográficas não podem parar apenas na localização, quer do espaço territorial, quer das relações, entre o objeto espaço físico, e as ações humanas, que o modificam.

É essencial pensar em como introduzir, por exemplo, as Anamorfoses nas aulas de Geografia. Esta não é uma das propostas deste trabalho, assim como evidenciar a necessidade de novas discussões para levar esse material cartográfico às aulas no ensino fundamental e médio a partir do ciclo II.

Com as anamorfoses, obtêm-se as respostas às perguntas: O quê? Quanto ou em que ordem? E Onde? (BERTIN, 1988, p.47) que devem ser feitas sobre os fenômenos e que podem ser respondidas visualmente. Como esses dados se relacionam, também é possível saber. 
Entende-se, no entanto, que há uma questão que poderá surgir, ou não, sobre a condição monossêmica das anamorfoses. Mas, não seria o caso, ao se pensar no processo de ensino e de aprendizagem, de inseri-las na sala de aula de Geografia devido a sua resposta visual imediata? Se o mapa funciona enquanto linguagem visual, esta outra possibilidade cartográfica não seria também produtiva no ensino? Não haveria neste caso uma dupla vantagem, pois ao lado das anamorfoses, inicialmente se colocaria um mapa de referência, o que permitiria ao aluno familiarizar-se com as duas maneiras de representar os fenômenos e não naturalizar a métrica euclidiana como a única possível? Este tipo de mapa, como uma linguagem instantânea, visual, atemporal (Cf. Fonseca e Oliva, 2002, p.68-69) não seria mais bem aproveitado e contribuiria mais nas aulas de Geografia no ensino fundamental e médio onde se vive a necessidade de explicitar o processo de globalização, por exemplo, que "opera uma reestruturação constante do espaço geográfico na contemporaneidade" (DURAND, 2006, p. 437).

Não se quer afirmar que só o "ver" levaria o aluno a entender as reestruturações ocorridas no espaço. Quer-se enfatizar que para uma cartografia escolar cognitiva, mais produtiva no ensino, as discussões sobre os temas tratados em aula deveriam ser iniciadas com mapas mais cognitivos. $E$ as anamorfoses não seriam uma opção? Portanto não haveria a necessidade de discussões acadêmicas no campo da renovação da cartografia que atingissem esse objetivo?

Neste trabalho apenas discorre-se teoricamente sobre a aplicação de anamorfoses. É preciso lembrar que os exercícios preparados para a aplicação prática da pesquisa não tratam da construção, mas apenas da visualização e da leitura de anamorfoses, por exemplo.

Jacques Bertin e Roberto Gimeno afirmam que se a gramática da representação gráfica fosse observada nos mapas presentes no ensino, já se obteria ganhos cognitivos tanto para os alunos como para os professores:

Experiências realizadas atualmente em várias classes da escola de $1^{\circ}$ grau mostram que os métodos gráficos permitem conduzir as crianças e os professores:

- a descobrir por eles mesmos as bases da semiologia gráfica;

- aplicá-las à cartografia

- a definir com rigor os elementos de apreciação de cada desenho;

A descobrir as diferentes utilidades do mapa e a fazer da aula de cartografia, ligada a muitos outros domínios, não somente uma atividade fundamental, mas também uma aula alegre [...] ( BERTIN e GIMENO, 1982, p. 39 ). 
Portanto, entende-se que este trabalho seja relevante para o ensino e a aprendizagem em Geografia escolar, uma vez que segue as orientações na busca do desenvolvimento de competências e habilidades tanto em alunos como em professores que trabalhem com a cartografia como linguagem e também para a compreensão da linguagem geográfica. 


\section{REFLEXÕES SOBRE A PRÁTICA PEDAGÓGICA}

Não se tem a pretensão de discutir neste capítulo as amplas questões relacionadas à educação e nem à prática docente e esgotar o assunto. Mas, durante a vivência da sala de aula, na prática educativa no ensino de Geografia, surgiu a necessidade de tecer uma discussão, ainda que brevemente, sobre questões que parecem ser urgentes e necessárias. Estas, relacionadas à didática e à "prática pedagógica, entendida como contexto social fundamental pelo qual ocorre a produção-reprodução cultural" (DANIELS, 2003, p.93). Pretende-se também, por meio de alguns questionamentos, evidenciar o ensino da gramática da representação gráfica, portanto, da linguagem dos mapas, para o ensino e a aprendizagem em Geografia escolar.

O que é o ensino, como o professor deve interferir e participar dele, como se dá a aquisição do conhecimento pelos alunos, e finalmente como a Geografia escolar por meio dos trabalhos com mapas pode e deve colaborar para 0 desenvolvimento cognitivo dos alunos a partir do ciclo II, são algumas das questões que serão verificadas.

\subsection{O ensino}

Tem-se por pressuposto que a escola se constitui em uma parcela da sociedade. É nela que os horizontes dos alunos se ampliarão a partir das relações familiares básicas, ao convívio social mais amplo. Novas oportunidades surgirão e permitirão o ingresso da criança num universo novo a ser compartilhado. Então, qual seria o papel da educação formal? Qual deveria ser a postura do professor de Geografia nesse novo contexto educativo? Qual seria a atividade prática pedagógica ideal para professores e alunos? Qual o nível de desenvolvimento cognitivo dos alunos, já a partir do ciclo II, que Ihes permitisse a aquisição dos novos conhecimentos?

$\mathrm{Na}$ busca de algumas das respostas inicia-se com as colocações de Alexis Leontiev que procura esclarecer o papel da cultura criada pela sociedade e o fato de que tudo o que o homem tem de humano derivar da vida em sociedade. Segundo o 
autor, somente a apropriação das aquisições históricas da humanidade, no curso de sua existência é que permitiria aos homens adquirir propriedades e faculdades verdadeiramente humanas (Cf. Leontiev, 1978, p. 261 e 283 ).

A escola, nesse contexto, seria o espaço privilegiado do aprender, pois será nela que os alunos terão acesso ao conhecimento institucionalizado, à educação formal. É na escola que a educação, um fenômeno social e socializador, terá a finalidade de promover o desenvolvimento das pessoas. É ela que, como instituição social que é, e tendo funções educativas, encarrega-se de dar um sentido ao desenvolvimento humano. (tradução nossa) (Cf. G.I.E., 1991, p.5).

J. Gimeno Sacristán aponta para o fato de que:

Embora a escolarização implique uma certa forma social característica de organizar a educação, há uma certa continuidade com a prática de criar os filhos e com as relações sociais extra-escolares, historicamente anteriores ao fenômeno da escolarização. (SACRISTÁN, 1991, p. 70).

O autor ainda tece considerações sobre o fato de a evolução da sociedade colocar à escola um conjunto cada vez mais amplo de funções, tornando-as cada vez mais indefinidas. Caracteriza o ensino como social e socializador, devido à possibilidade de interação entre atores, e ao fato desses atores refletirem, no espaço escolar, a cultura e os contextos sociais a que pertencem. (SACRISTÁN, 1991, p.66$67)$.

Mas, quais seriam esses contextos? Certamente a formação do professor é relevante para identificar parte do seu contexto e essa questão será retomada posteriormente.

Entende-se, ainda com o mesmo autor, que não são apenas os contextos da formação profissional que estão envolvidos no processo de ensino e aprendizagem. Ainda há que se pensar sobre os contextos que envolvem os alunos fora da escola, inclusive. Tem-se que considerar que aquilo que denominamos educativo remete a outras esferas de ação que acabam por "incidir sobre a realidade escolar imediata". (SACRISTÁN, 1991, p. 68).

Em outras palavras seria necessário estar atento a que contexto social, por exemplo, tanto alunos como professores que chegam à escola refletem. Nesse sentido J. Gimeno Sacristán afirma que "os indivíduos não são passivos e também participam na mudança de contextos" (SACRISTÁN, 1991, p. 65).

A importância dada aos contextos é levantada por Pilar Lacasa ao informar que é preciso verificar questões referentes à sala de aula tais como: "Quais seriam 
as situações educativas que seriam mais eficazes para o ensino? Afirma ainda que é preciso considerar que a interação social nem sempre parece ter efeitos positivos" (tradução nossa) (LACASA, 1994, p. 303).

Sendo assim, optou-se nesse caso, por considerar uma situação didática que molda o contexto da sala de aula e que é apresentada por Jacques Bertin e Roberto Gimeno, por intermédio da qual as crianças participariam do processo de construção de mapas temáticos. Os autores partem do princípio que não se desenha um mapa, mas se constrói, respeitando a gramática da representação gráfica de dados em atividades de construção de mapas que permite o trabalho em grupo também. Assim será possível verificar se nas atividades propostas aos alunos para construção desse material, onde deverá ocorrer um tratamento gráfico de dados apresentados em tabelas, a interação social apresente resultados positivos dentro do contexto que se encontrará no momento de sua realização.

Pode-se adiantar que Jacques Bertin e Roberto Gimeno verificaram a aplicabilidade do tratamento gráfico de dados em todos os domínios da atividade escolar. Nas situações de aprendizagem que eles aplicaram, as atividades permitiram o desenvolvimento cognitivo dos alunos (Cf. Bertin e Gimeno, 1982), sendo assim afirma-se:

Que a imagem gráfica, tal como é aqui utilizada, pode também se constituir em um método de ensino, novo, dinâmico e moderno que ajuda a criança a construir o pensamento lógico a partir de uma forma visual que ela mesmo (sic) elabora (BERTIN e GIMENO, 1982, p.36).

Entende-se, junto com os autores, que para o ensino de Geografia, as situações didáticas sugeridas ainda podem ser consideradas novas e modernas, e um recurso para as atividades práticas na Geografia escolar. $\mathrm{O}$ caso é que muitos autores ainda chamam a atenção para o fato de o mapa ser subutilizado no ensino, como mencionado anteriormente.

Dentro dessa possibilidade, a de trabalhar com mapas em Geografia e frente à sua subutilização, as preocupações emanadas da observação empírica do dia a dia com relação ao exercício prático do ensino de Geografia trouxeram ainda várias outras interrogações, e entre elas sobre a didática. A colocação de Lana de Souza Cavalcanti nos auxilia nesse quesito: 
dinâmica e subjetiva, não limitada a uma correta aplicação de regras gerais e procedimentos.

Nessa perspectiva, a Didática da Geografia busca compreender a dinâmica do ensino, seus elementos constitutivos, suas condições de realização, seus contextos e sujeitos envolvidos, seus limites e desafios. (CAVALCANTI, 2010, p. 368).

Neste caso, entende-se que cabe ao professor ou professora uma constante reflexão sobre a sua profissão. Refletir significa pensar e procurar respostas para os problemas de ensino e aprendizagem vivenciados na sala de aula. Mario Sergio Cortella afirma: "A prática de pensar a prática - o que fazemos - é a única maneira de pensar - e de fazer - com exatidão" (CORTELLA, 2005, p.112). Assim, uma ponderação constante, permitira pensar estratégias de ação embasadas nas teorias existentes e nas situações vivenciadas na prática cotidiana para resolver os problemas que surgem durante o processo de ensino e aprendizagem.

Optou-se neste trabalho pensar e propor atividades sob o enfoque socioconstrutivista, onde a interação com o meio permitirá ao aluno adquirir novos conhecimentos. Embora outras formas de interação social sejam conhecidas, e a teoria das situações didáticas de Guy Brousseau (BROUSSEAU, 2008) seja uma possiblidade, a proposta de trabalho em sala de aula que se realiza nesta pesquisa foi aplicada seguindo primeiramente as orientações das teorias de Vigotskii ${ }^{23}$.

Seguir-se-á as orientações teóricas do socioconstrutivismo e considera-se, junto com Alexis $\mathrm{N}$. Leontiev que a própria vida da criança é que determinará o desenvolvimento da sua psique. O que é real para ela, o que realmente ela pratica e vivencia é que propiciará o seu desenvolvimento.

O que determina diretamente o desenvolvimento da psique de uma criança é sua própria vida e o desenvolvimento dos processos reais dessa vida. Em outras palavras: o desenvolvimento da atividade da criança, quer a atividade aparente quer a atividade interna. Mas seu desenvolvimento, por sua vez, depende de suas condições reais de vida" (LEONTIEV, 1988, p. 63).

Ao se considerar que é na escola que a criança terá a oportunidade de desenvolver algumas atividades que poderiam levá-la a outros níveis de desenvolvimento cognitivo, a proposta de aplicação de exercícios de construção de

\footnotetext{
${ }^{23}$ Não há consenso com relação à grafia do nome Vigotskii que pode ser: Vigotskii, Vygotsky, Vigotsky. As publicações mais recentes têm adotado a grafia Vigotski. (PEREIRA et al, 2010, p.01). Nesta pesquisa optou-se pela grafia conforme a obra citada.
} 
mapas talvez possa colaborar nesse sentido. Entende-se que tanto a cultura como as atividades e as ferramentas às quais a criança tem acesso e faz uso serão determinantes para o seu desenvolvimento cognitivo.

A partir das colocações de Leontiev, e com os exemplos de atividades aplicadas por Jacques Bertin e Roberto Gimeno, será aplicado um questionário diagnóstico apresentada a gramática da representação gráfica, em aulas expositivas, para posteriormente os alunos serem capazes de ler, construir e interpretar mapas temáticos o que permitiria ganhos cognitivos para eles.

Num segundo momento, se pretende aplicar uma atividade a qual será chamada de "desafio", onde os alunos deveriam encontrar uma ordem visual para representar num mapa quatro classes numéricas, ordenando-as do menor para o maior, sem utilizar números ou letras ou ainda sinais $+/$ - ou $>/<$. Esta seria outra possibilidade de inserir as regras da gramática da representação gráfica nas aulas de Geografia. Os próprios Jacques Bertin e Roberto Gimeno afirmam que os alunos descobririam por si mesmos as regras da gramática da representação gráfica (Cf. Bertin e Gimeno, 1982, p.39). Portanto, pensa-se em duas situações de ensino que levariam à aprendizagem: Numa delas o professor, após a avaliação diagnóstica, ensina a gramática da representação gráfica conforme a Semiologia gráfica e apresenta uma tabela com os dados a serem representados no mapa. Depois os alunos escolheriam entre as variáveis visuais para fazer as suas representações, e na sequência poderiam ler e interpretar os mapas. Na outra os alunos seriam levados a descobrir essas regras sozinhos, para somente depois, o professor aprofundar o conhecimento com eles, levando-os a construir, ler e interpretar mapas temáticos.

É preciso ressaltar que as atividades sugeridas pelos autores serão aplicadas, mas sempre tomando o cuidado de verificar a sua eficácia para o ensino de Geografia e a aquisição de conhecimentos geo-cartográficos pelos alunos, como sugere Pilar Lacasa, uma vez que o contexto de sala de aula pode ser diferente em cada momento de aplicação das atividades. Esta observação torna-se relevante, quando se pensa que o público alvo das atividades práticas será formado por alunos a partir do $7^{\circ}$ ano do ensino fundamental, $1^{\circ}$ ano ensino médio regular e $1^{\circ}$ ano ensino médio na modalidade Educação de Jovens e Adultos (EJA). A observação ocorrerá em todas as salas inclusive, devido ao contexto específico de cada uma delas, que envolve a professora e os alunos. 
Entende-se que o professor atento, observador, questionador de suas ações, posicionamentos, e de sua ideologia, certamente terá melhores resultados com os quais trabalhar. Paulo Freire afirma: "A reflexão crítica sobre a prática se torna uma exigência da relação Teoria/Prática [...]" (FREIRE, 1996, p. 22). Estas recomendações devem permear, durante todo o tempo, as atividades realizadas com os alunos e a pesquisa de um modo geral.

Se o professor deve estar atento às relações teoria/prática, e assim o fizer, não seria o caso, então, de levar em consideração as observações de sala de aula para construir teorias que ajudem no referido processo de ensino-aprendizagem? É uma das propostas desta pesquisa frente à observação empírica da necessidade de se trabalhar com anamorfoses no ensino de Geografia, por exemplo.

Outra questão a considerar é a necessidade de prestar atenção ao desenvolvimento cognitivo de cada aluno, pois permite, no momento de aplicação das atividades com mapas, verificar as diferentes maneiras que cada aluno se relaciona com o que é ensinado. Essa postura possibilita informar aos alunos que os mapas produzidos por eles nas atividades propostas não serão considerados mapas errados ou mapas certos. Todos os mapas teriam o seu valor na aprendizagem, e o erro, inclusive (Cf. Cortella, 2005, p.112). O que importa é a participação deles, seu envolvimento nas atividades propostas. As possíveis correções seriam realizadas somente após o ensino da gramática da representação gráfica. Neste caso os alunos poderiam ver onde e em que se enganaram para poder adequar os conhecimentos adquiridos.

Nesse sentido há várias observações a serem colocadas, e como oportunamente questiona Rita Simone Soares Vignoli "Na prática a Teoria é outra?" (VIGNOLI, 2003).

Em seu trabalho a autora afirma que se não se tomar a prática como fundamentação teórica, inclusive, sim, na prática a teoria será outra. Fazer com que a teoria abarque as necessidades que são identificadas na prática já era uma necessidade da Educação nas décadas de 80 e 90 . E ainda afirma que instituições externas ao universo escolar, têm imposto reformulações ao currículo ${ }^{24}$. Ressalta que, mesmo que tenham um caráter questionável, justamente por serem externas ao

\footnotetext{
${ }^{24}$ Referindo-se ao nível de Ensino Normal, que é a discussão de seu trabalho (VIGNOLI, 2003). Mas se aceita a mesma colocação no atual contexto educacional com relação à educação básica, ciclo II em diante, no estado de São Paulo.
} 
contexto educativo, por não saberem exatamente o que é preciso e urgente à educação na prática, pois estariam distante da realidade diária, ainda há a possiblidade de resistência às referidas reformulações. A atuação dos professores seria fundamental nesse aspecto, pois eles é que efetivam o currículo. Ou seja, o que realmente acontece em sala de aula é de responsabilidade efetiva desse profissional, é ele que decidirá como trabalhará o currículo (Cf. Vignoli, 2003, p.44).

Portanto, entende-se que o que deverá ser ensinado, embora venha até a escola por intermédio de políticas públicas, como é o caso no Estado de São Paulo, o ensino de fato, é de responsabilidade do professor.

Sendo assim, entende-se que seja necessário proceder à observação de algumas das políticas públicas ${ }^{25}$, inclusive para a educação básica, ciclo II em diante na disciplina escolar Geografia, pois elas é que têm estruturado o currículo que os professores efetivarão cotidianamente. Uma vez que o público alvo desta pesquisa serão alunos das escolas públicas do estado de São Paulo, e tendo-se por orientação a aplicação de uma base curricular única, oferecida pela proposta curricular e oficializada posteriormente pelo Currículo oficial, tomou-se o cuidado de observar o que orienta esse currículo estadual.

Na exposição do documento afirma-se que ele:

apresenta os princípios orientadores do currículo para uma escola capaz de promover as competências e habilidades indispensáveis ao enfrentamento dos desafios sociais, culturais e profissionais do mundo contemporâneo. (SÃO PAULO, 2010, p. 07).

Partindo desse pressuposto verificou-se então o que se indicava para o ensino de Geografia no currículo estadual. A proposta inicial poderia ser entendida como uma possibilidade de aplicação de uma Geografia renovada, pois apresenta o espaço geográfico sobre o olhar das teorias de um autor como Milton Santos. Traz também autores que tratam a educação sob uma óptica do desenvolvimento de

\footnotetext{
${ }^{25}$ A Secretaria de Estado da Educação de São Paulo (SÃO PAULO, 2008) apresentou aos professores em exercício na rede estadual as iniciativas para a organização do currículo que as escolas públicas do estado de São Paulo deveriam efetivar, mas o material foi chamado inicialmente de Proposta curricular. A partir de 2010 essa proposta foi oficializada como o Currículo Estadual de São Paulo, com uma série de medidas que a acompanhavam. Entre elas a política de valorização pelo mérito, que pressupõe avaliações periódicas para os professores na busca de aumento salarial; o bônus por resultado, atrelado aos resultados obtidos pelos alunos nas avaliações externas, caso do Saresp e a formação continuada de professores, com a criação, inclusive, da Escola de Formação de professores que oferece cursos online, mas apenas para professores em processo de efetivação na rede pública estadual, objetivando primeiramente implementar a então Proposta curricular e depois o atual Currículo estadual.
} 
competências e habilidades que preparariam os alunos para uma educação do futuro (MORIN, 2001, apud SÃO PAULO, 2010, p. 75), na percepção do processo de globalização (GIDDENS, 2000, apud SÃO PAULO, 2010, p. 75-76) e da compressão do tempo-espaço (HARVEY, 1996, p. 219, apud SÃO PAULO, 2010, p. 76) ${ }^{26}$. Nos materiais há uma grande quantidade de mapas e atividades relacionadas tanto à leitura e interpretação dos mesmos como, na $1^{\text {ạ }}$ série do ensino médio há uma apresentação completa do quadro das variáveis visuais ${ }^{27}$, e da gramática da representação gráfica com situações de aprendizagem atreladas a elas. Segundo os autores o objetivo é que nessa série e nível de ensino os alunos poderiam se apropriar dessa gramática e sua aplicação para as atividades com mapas, embora desde 0 6ำ ano já seja possível verificar a presença de trabalhos com leitura de mapas em diferentes escalas (SÃO PAULO, 2010) ${ }^{28}$.

Alguns mapas dos cadernos obedecem criteriosamente às regras da gramática da representação gráfica. Outros não necessariamente. Mas, uma vez que o material já está nas mãos dos alunos, pensa-se que o ideal seria optar por trabalhar os erros cartográficos verificados em algumas das situações de aprendizagem $^{29}$ dos cadernos. Para moldar a situação sugerida para uma situação de ensino e aprendizagem ideal, em conformidade com a gramática da representação gráfica, os alunos deveriam construir um mapa que mostrasse visualmente onde há uma maior concentração de desenvolvimento técnico-científicoinformacional. Eles utilizariam a variável visual valor, em modo de implantação

\footnotetext{
${ }^{26}$ O material é apresentado ao professor como "apostilas" que são chamadas de "Cadernos do professor". A cada caderno do professor corresponde um "caderno do aluno", por bimestre, com atividades que são denominadas "situações de aprendizagens". O referido material foi preparado por geógrafos e professores de Geografia.

${ }^{27}$ Oportunamente se apresentará o quadro explicativo sobre essas variáveis, que são parte da gramática dos mapas.

${ }^{28}$ Esta referência é feita a todo o material do currículo de Geografia utilizado desde o $6^{\circ}$ ano do ensino regular até o $3^{\circ}$ ano do ensino médio na disciplina de Geografia. Os cadernos e volumes que foram utilizados na pesquisa constam da lista de referências bibliográficas.

${ }^{29}$ Entende-se que mesmo o aluno se deparando com um mapa onde houve a inversão da informação, pois onde deveria ser colocado o valor da cor mais intenso foi colocado o valor menos intenso, portanto visualmente inverteu-se a informação, ele poderia ser levado a construir um novo mapa. $O$ mapa original, como construído e apresentado no referido caderno, apresenta uma ordem visual que traz a região Nordeste com uma cor mais intensa referindo-se a uma situação de aprendizagem que deveria mostrar visualmente, por intermédio do mapa em questão, a região concentrada (SÃO PAULO, 2010, p. 37).
} 
areolar e demonstrariam visualmente uma hierarquia, num mapa ordenado, onde a região concentrada apareceria com o valor mais intenso.

Entende-se que esta atividade poderia ser bastante enriquecedora para o processo de ensino e aprendizagem. O professor direciona o ensino, uma vez que este é de sua responsabilidade imediata.

Este é apenas um exemplo de como os mapas presentes no referido material poderiam ser utilizados pelo professor de Geografia para permitir a aquisição de novos conhecimentos. Em se tratando de mapas presentes em livros didáticos, que também apresentam muitos mapas incorretos segundo a gramática da representação gráfica, não seria conveniente também fazer as correções junto com os alunos? O fato é que cabe ao professor não permitir que um documento que chega à sala de aula com erros cartográficos ou um erro conceitual, por exemplo, não seja discutido em sala de aula. Esta sugestão de situação de ensino e aprendizagem poderia passar despercebida, caso a gramática da representação gráfica não fosse conhecida pelo professor. Conhecendo-a, ele tem a possibilidade de mesmo ao receber um material pronto, com o qual deveria trabalhar com seus alunos, modificar a proposta que lhe é dada em benefício do processo de ensino e aprendizagem.

Evidencia-se, no entanto, que o mais adequado seria que todo o material didático com 0 qual os alunos terão contato estivesse correto. Mas, na impossibilidade, dependendo dos materiais que deverão ser utilizados em aulas de Geografia na rede pública de São Paulo poder-se-ia fazer a sugestão de adaptação acima. Este fato vem apenas reforçar o que se propõe neste trabalho. Que o professor conheça as possibilidades de aplicação da gramática da representação gráfica, as anamorfoses e os mapas de fluxo, para o ensino de Geografia a partir do ciclo II, só assim ele poderá intervir e adequar o que for necessário.

Retoma-se, então a questão do currículo estadual para, especificamente com relação à Cartografia no ensino de Geografia, verificar que ele aponta uma série de competências e habilidades a serem desenvolvidas na escolarização, onde a alfabetização cartográfica merece destaque. Entre os objetivos enumerados no referido documento, entende-se que é preciso ressaltar: "Elaborar, ler e interpretar mapas e cartas" (SÂO PAULO, 2010, p. 79). 
Sendo assim, os trabalhos que serão realizados na aplicação prática desta pesquisa estariam satisfatoriamente adequados a essas orientações ${ }^{30}$. Todavia, 0 próprio documento salienta que nada impede que o professor adeque as atividades às necessidades verificadas no dia a dia (Cf. São Paulo, 2010, p. 81). O que na prática, diante da orientação de justificar as adequações necessárias, parece contraditório.

Sendo assim, e não só para o Estado de São Paulo, entende-se que quando vai para a sala de aula, o professor deve ter pensado sobre o currículo, mas já vislumbrando possíveis e necessárias adequações. Esse posicionamento o levará a agir em sala de aula na busca de atingir os objetivos propostos para as situações de ação e atividade direcionadas.

Nesse caso, deve entender que o currículo, principalmente, cumpre um papel norteador. Entende-se que, se deve haver um trânsito de influências com outros agentes, e neste caso, as políticas estaduais ou nacionais de educação, um currículo estático não cumprirá a sua função investigativa, como afirma o Grupo de investigação na escola (Cf. G.I.E., 1991, p.5). Nesse sentido o professor deve encarar o ensino como um "problema" a ser resolvido e, portanto, que envolve uma constante reflexão sobre a prática educativa. Embora, entenda-se que esse currículo não dependa unicamente do professor, mas, a sua concretização sim. Há, inclusive, a necessidade de que o professor tome consciência de que não há neutralidade no ensinar, e que o ensino é permeado pelas suas próprias ideologias, para que ele seja coerente com a sua postura. O contexto do professor está implícita ou explicitamente presente na sua prática de ensino.

Concorda-se com Paulo Freire quando afirma:

[...] a educação é uma forma de intervenção no mundo. Intervenção que além do conhecimento dos conteúdos bem ou mal ensinados e/ou aprendidos implica tanto o esforço de reprodução (grifo do autor) da ideologia dominante quanto o seu desmascaramento (grifo do autor).

\footnotetext{
${ }^{30}$ É importante destacar que a pesquisa não foi direcionada pelo currículo estadual. O projeto de pesquisa já existia antes da implementação do referido currículo estadual. O que se fez foi apenas verificar como eram direcionadas as orientações do currículo ao levar a pesquisa para a sala de aula. Entendeu-se que seria necessário verificar estes parâmetros, pois estar em exercício na escola pública estadual também requer uma observação constante sobre as atividades desenvolvidas com a finalidade de procurar adequar conteúdos e atividades a uma base comum para a educação no Estado. O que é o propósito do currículo estadual de São Paulo neste momento, a busca da base comum. A observação ocorreu pelo fato de que, tudo o que for realizado fora do que é proposto no documento deverá ser justificado oficialmente, o que se faria, caso as atividades propostas nos trabalhos realizados na pesquisa em sala de aula não contemplassem pelo menos parte do currículo.
} 
Dialética e contraditória, não poderia ser a educação só uma ou só outra dessas coisas (FREIRE, 1996, p. 98).

J. Gimeno Sacristán coloca da seguinte maneira:

A sua conduta profissional pode ser uma simples adaptação às condições e requisitos impostos pelos contextos preestabelecidos, mas pode também assumir uma perspectiva crítica, estimulando o seu pensamento e a sua capacidade para adotar decisões estratégicas inteligentes para intervir nos contextos (SACRISTÁN, 1991, p.74).

E aqui, se deve ter em mente, que o currículo não é formado apenas pelo seu conteúdo explícito (formal), mas também pelo oculto (implícito), que tem tanto ou mais força no momento de aula do que propriamente o currículo explícito. Daí surge a necessidade da coerência entre o que o professor faz e o que ensina. O Grupo de Investigação na escola esclarece:

[...] 'currículo oculto' (implícito), entendido como o conjunto de fatores (interesses, expectativas, ideologias...) que, ainda que não se manifeste claramente na programação do professor, constituem um autêntico projeto instrucional que guia sua ação. [...]o professor atua como reprodutor de valores sociais que não se costumam incorporar aos grandes fins da educação, e que, precisamente por isso, são mais difíceis de situar e criticar (tradução nossa), (G.I.E.,1991, p.12).

Nestor Kaercher ${ }^{31}$ coloca: "O que mais educa o educando são os exemplos" e o autor faz questão de afirmar "todos os exemplos".

Janine Gisele Le Sann menciona em seu trabalho as considerações feitas por Clarapède no tocante à falta de reconhecimento dos professores com relação à sua prática educativa.

O objetivo da educação deve ser o desenvolvimento das funções intelectuais e morais mais do que encher a cabeça de uma massa de conhecimentos que (quando não são esquecidos) permanecem, na maioria dos casos, conhecimentos mortos, alojados na memória como corpos estranhos, sem ligação com a vida. (CLARAPÈDE, $1921^{32}$, p. 43, apud LE SANN, 2008, p. 99).

Pensar a educação, portanto, não é coisa recente. Mas esta observação permite pensar que após todos esses anos e transformações ocorridas na esfera educativa, ainda há a necessidade de se retomar as observações feitas pelo autor. Poder-se-ia pensar então que as bases para a educação ainda permanecem em processo de construção?

\footnotetext{
${ }^{31}$ Da Universidade Federal do Rio Grande do Sul em mesa redonda do dia 14/08/2008 no Seminário Internacional de Geografia e Ciências, na Faculdade de Educação da USP, que ocorreu no período de 13 a 15 de agosto de 2008.

32 Janine Gisele Le Sann cita Clarapède apud Ulmann, conforme segue: ULMANN, J. La pensée éducative contemporaine. Paris: Vrin, 1982.
} 
Ainda assim, é possível afirmar que a observação atenta do professor, no seu cotidiano escolar, permitirá identificar se os conhecimentos que pretende levar aos seus alunos estão se tornando conhecimentos vivos para eles. Atividades diagnósticas, apresentação de conteúdos adequados ao público alvo em questão, aulas expositivas, trabalhos com tabelas, leitura, interpretação e construção de mapas segundo a gramática da representação gráfica, trabalhos com anamorfoses podem ser uma possibilidade de alcançar esse objetivo a partir dos 6ํㅡㅁ anos do ensino fundamental na disciplina de Geografia. Esta é a proposta de trabalho sugerida nesta pesquisa.

Nesse sentido, a postura do professor, seu compromisso com seu trabalho também é parte do processo educativo e da formação de seus alunos.

Portanto, mais uma vez é preciso destacar que o que permitirá o desenvolvimento das habilidades e competências não é uma quantidade enorme de conteúdos, que como coloca Paulo Freire, "podem ser bem ou mal ensinados e aprendidos" (FREIRE, 1996, p. 98). A questão para a concretização do ensino seriam as situações de aprendizagem? Levar o aluno a assimilar os conteúdos, interagir com eles e desenvolver-se não seria uma questão de quantidade, mas do quê e de como ensinar?

É preciso lembrar ainda, que existe a questão que envolve o próprio desenvolvimento cognitivo do aluno ao chegar à escola, e mesmo ao fato de apenas estar na escola. Como afirmam os autores que discutem o desenvolvimento da psique infantil, já mencionados, o nível de desenvolvimento cognitivo dos alunos depende de como e do quanto eles se envolvem e praticam atividades.

Se se pensar no que propõe o Currículo estadual de São Paulo com relação à quantidade e a todos os procedimentos e temas que devem ser trabalhados por bimestre, tem-se que os professores se veem obrigados a dizer que trabalham tudo, mas a realidade é outra. É preciso lembrar que os referidos conteúdos e atividades serão aferidos em avaliações externas. Trabalhar tudo não significa ter ensinado e menos ainda ter efetivado a aprendizagem, significa apenas ter cumprido com o que é exigido quantitativamente. E o desenvolvimento de competências e habilidades será que ocorreu? Entende-se que seria quase impossível ter alcançado esse objetivo nessas condições.

Reitera-se, no entanto, que o professor deve considerar o currículo como um norte (Cf. G.I.E., 1991, p.5), apenas uma direção a seguir, e com o currículo 
estadual de São Paulo não deveria ser diferente. Neste caso, ele se tronaria útil para o ensino, uma vez que o que os autores propõem é uma base estadual comum, mas com qualidade, que talvez se mostre necessária para o próprio processo de ensino e aprendizagem, com relação aos alunos que tiverem necessidade de se deslocar de uma escola para outra dentro do Estado.

Entender que as atividades de ensino e aprendizagem são processos, portanto movimentos articulados entre si e que estão presentes na sala de aula numa constante dialética. E ainda, que são merecedoras de uma reflexão crítica permanente por parte do docente, não seria um ponto chave para esclarecer o papel da quantidade em detrimento da qualidade do que se ensina? Se a base comum negligenciar a qualidade do que se pretende ensinar, a que se resumirá?

É preciso ter em mente também que para serem realmente efetivadas, essas situações de aprendizagem exigem preparo. Ou seja, o professor deve ter tido uma boa formação. Estar em constante formação, pois "a maneira mais segura e direta de se incidir sobre o currículo é incidir sobre os docentes, sobre sua formação e suas condições de trabalho" (TORRES, 2000, p. 156, apud VIGNOLI, 2003, p. 44).

Paulo Freire reforça esta observação quando afirma:

O preparo científico do professor ou da professora deve coincidir com sua retidão ética. É uma lástima qualquer descompasso entre aquela e esta. Formação científica, correção ética, respeito aos outros, coerência, capacidade de viver e de aprender com o diferente [...] (FREIRE, 1996 p.1617).

Lívia de Oliveira afirma, em relação à Geografia, que é preciso que no currículo de formação de professores seja incluída a disciplina Cartografia escolar, mas que essa cartografia deve ser mais direcionada à Geografia e menos à matemática. A autora ainda coloca que o professor deve trazer "em sua bagagem profissional conhecimentos sobre o desenvolvimento da criança e do adolescente". (OLIVEIRA, 2008, p. 24). Assim, se o professor não tiver consciência de que os alunos apresentam níveis de desenvolvimento cognitivo diferentes não adianta afirmar que ensina. E menos ainda que ensine a todos com as mesmas situações de aprendizagem, sem o cuidado de observar se ocorre interação entre os alunos. Se, eles compartilham o que já sabem.

Segundo Telma Weisz

Para interpretar adequadamente o que está acontecendo com a aprendizagem de seu aluno, o professor precisa de um conhecimento que é 
produzido no território da ciência. Isso porque, na verdade, a gente consegue ver apenas o que tem instrumentos para compreender (WEISZ, 2009, p.24).

Além disso, a autora afirma que será muito difícil para o professor manter-se dentro de uma visão construtivista a menos que ele procure se lembrar o tempo todo, que o seu olhar não é igual ao da criança. O fato é que o professor vê o conhecimento de onde ele já está construído, e então surge a necessidade de apoiar-se num conhecimento científico disponível. Esta seria a "única forma de recuperar o olhar da criança, que ainda está em processo de construção" (WEISZ, 2009, p. 29). Segundo essas orientações não seria possível pensar que o que se pretende ensinar será aprendido literalmente conforme é ensinado. Cada aluno fará a aquisição daquilo que o seu contexto particular permitir. Poder-se-ia falar em uma reconstrução do conhecimento pelo aluno?

Nessa direção tem-se que Piaget identificou que crianças entre 09-10 e 11-12 anos, estão "finalizando a estruturação dos sistemas ligados ao espaço e ao tempo" (LE SANN, 2008, p. 102). É notório que as teorias vigotskianas enfatizam que não é a idade pela idade que determina o nível de desenvolvimento cognitivo das crianças. Pode haver uma possibilidade de crianças entre 11-12 anos de idade já terem finalizado a estruturação dos tais sistemas ligados ao espaço e ao tempo. Janine Gisele Le Sann identificou que, por exemplo, nas questões da interpretação da escala, às vezes falta aos adolescentes uma ou outra estrutura cognitiva para que eles trabalhem com essas questões. Ela coloca que há a necessidade de uma estrutura cognitiva já desenvolvida no aluno para que ele possa trabalhar com as noções de escala. Esta observação é verdadeira para a aquisição de qualquer novo conhecimento.

Marco Antônio Moreira ajuda a entender o que se coloca e trata de subsunçores. Se a estrutura cognitiva é clara e estável; ou instável, ambígua e desorganizada, ocorrerão situações de aprendizagem diferentes. Ele, por meio da apresentação da teoria ausubeliana demonstra que, conforme as características das estruturas cognitivas dos estudantes poderão ocorrer ou uma aprendizagem significativa ou uma aprendizagem mecânica. "Portanto, é principalmente pela aquisição de uma estrutura cognitiva adequada (isto é, com aspectos relevantes, claros, estáveis e hierarquicamente organizados) que a nova aprendizagem e a retenção são facilitadas" (MOREIRA, 2006, p.168). 
Para que o ensino se efetive, é preciso que haja uma troca de significados entre professor e aluno sobre determinado conhecimento. Um caminho deve ser percorrido até que ambos compartilhem significados comuns. Assim, ao compartilhar significados o aluno incorporaria a estrutura conceitual da matéria de ensino à sua estrutura cognitiva sem imposição. Portanto, uma interação social que levaria à aprendizagem significativa (Cf. Moreira, 2006, p.168-169-184). O autor destaca que não é o uso de uma ou outra estratégia que caracteriza um ensino que objetiva a aprendizagem significativa. A questão principal para este tipo de aprendizagem desejável seria a estrutura cognitiva identificável e identificada a partir da qual seriam pensadas estratégias de ensino. Segundo o autor o papel do professor envolveria quatro tarefas fundamentais, entre as quais "Ensinar utilizando recursos e princípios que facilitem a passagem da estrutura conceitual da matéria de ensino para estrutura cognitiva do aluno de maneira significativa" (MOREIRA, 2006, p.171). É o que se pretende com as atividades propostas neste trabalho para a prática de ensino em Geografia. No entanto, diante dos resultados das avaliações externas como o Saresp, por exemplo, que indicam níveis muito baixos de aprendizagem, não seria o caso de se considerar até mesmo a aprendizagem mecânica? Desde que o aluno aprendesse algo do que foi ensinado, não seria melhor do que não aprender nada?

Nesse sentido retoma-se a questão da interação social, dentro de uma perspectiva vigotskiana, inclusive, que vai desempenhar um papel central no desenvolvimento da criança. Portanto, é preciso levar em consideração, nas atividades práticas, que nem todos os alunos com os quais se trabalha na mesma sala, inclusive, seriam portadores de um mesmo nível de desenvolvimento cognitivo.

Uma vez que é sobre as atividades práticas que o professor deve estar atento de maneira geral, J. Gimeno Sacristán nos adverte que o conceito de prática é bem mais amplo do que aquele do universo escolar:

À educação referem-se acções muito diversas, que influenciam a prática didática. Nesta perspectiva é necessário alargar o conceito de prática, não o limitando ao domínio metodológico e ao espaço escolar. A prática não se reduz às ações dos professores [...] a prática da educação existiu antes que tivéssemos um conhecimento formalizado sobre a mesma e é anterior ao aparecimento dos sistemas formais de educação [...](SACRISTÁN, 1991, p.68-69) 
Deixa-se claro que aqui se discute a prática sobre a educação institucionalizada, ou a prática didática, e busca-se direcioná-la à disciplina de Geografia. Mas, seria o caso de se pensar que, em alguma medida, a observação feita pelo autor sobre a prática da educação existir antes mesmo de termos conhecimento formalizado, seria prejudicial à prática do ensino institucionalizado? Seria o caso de se pensar que qualquer um poderia acreditar que pode ensinar? Se a reposta for positiva, e todos acreditarem que podem ensinar, não estaria aí a razão para o descrédito na profissão de professor? Mas qual seria então o preço que o processo educativo teria que pagar? Qual seria a qualidade do ensino ministrado?

Fica evidente na fala dos autores a necessidade de compreensão, por parte do professor ou da professora, que o processo de ensino e aprendizagem não está unicamente sob sua responsabilidade. Mas entende-se que a sua participação é fundamental no espaço escolar, na sala de aula.

Assim discute-se aqui sobre o conceito mais imediato de prática, as atividades nas quais apenas o professor pode intervir diretamente e sobre as quais ele deve ser o responsável:

As práticas didáticas são da responsabilidade imediata dos professores, constituindo o conteúdo da profissionalidade docente num sentido técnico e restrito. $\mathrm{O}$ conceito mais imediato de prática remete-nos para as atividades docentes realizadas num contexto de comunicação interpessoal [...] (SACRISTÁN, 1991, p. 73).

O mesmo autor traz uma crítica a alguns procedimentos tidos como normais em sala de aula e no cotidiano escolar:

Todo o desenvolvimento curricular, formulado e elaborado fora das salas de aula e das escolas, regulado pela administração educativa, traduzido e concretizado em materiais didáticos, transforma os professores em consumidores de práticas preesboçadas fora do teatro imediato da ação escolar. Ao nível da realidade das salas de aula, as editoras de manuais escolares e outros produtores de materiais didáticos têm mais influência do que os próprios professores. (SACRISTÁN, 1991, p. 73-74).

É possível entender então que o professor ou professora deve ser autor de suas aulas e trabalhar efetivamente na formulação do currículo escolar? Ou seria mais conveniente o que acontece atualmente na rede pública do estado de São Paulo como apresentado anteriormente?

Se o professor tem que se responsabilizar por ele, ou pelo menos pela parte prática das atividades didáticas, não seria mais conveniente que esse profissional 
pudesse acompanhar seus alunos, por exemplo, do $6^{\circ}$ ao $9^{\circ}$ ano e durante todo 0 ensino médio? Talvez um professor de Geografia que tivesse a oportunidade de trabalhar com as mesmas turmas de alunos durante o ensino fundamental, pudesse ir adequando seu trabalho às necessidades verificadas durante cada ano letivo. Assim, mediante as reformulações ocorridas em determinado ano, ele, professor, poderia pensar em reorganizar/replanejar o currículo para a mesma série do próximo ano. Ao mesmo tempo, por já conhecer os alunos com os quais trabalhou no $6^{\circ}$ ano no ano letivo anterior, por exemplo, ao reencontrá-los no $7^{\circ}$ ano, já os conheceria e às suas dificuldades e possiblidades. Isso não facilitaria muito seu trabalho prático? Entende-se que, mesmo num período de férias os alunos podem mudar de nível de desenvolvimento cognitivo, dependendo das necessidades práticas com as quais ele se deparar e nas quais tiver que intervir. A percepção dessa mudança não seria mais fácil para um professor que já tivesse trabalhado com o referido aluno no ano letivo imediatamente anterior? O que se percebe na rede de ensino do estado de São Paulo não é esse cuidado no processo de atribuição de aulas.

J. Gimeno Sacristán levanta a questão sobre a utilização dos materiais didáticos como práticas pré-esboçadas. Como é possível o professor aceitar que o material mais utilizado em sala de aula de Geografia seja o livro didático e algumas vezes o atlas geográfico escolar? Ou mesmo os cadernos de aluno e professor oferecidos pela Secretaria de Estado da Educação de São Paulo, que são materiais prontos e que foram pensados por outros autores? Fernanda Padovesi Fonseca ${ }^{33}$ afirma:

\begin{abstract}
Levando-se em conta que os materiais didáticos mais presentes em sala de aula são os livros didáticos e algumas vezes o Atlas escolar, é necessário entender que num Atlas escolar o mapa temático é o recurso principal do trabalho do aluno (grifo nosso).
\end{abstract}

Considera-se que esses materiais não devem ser abolidos da sala de aula, pois existem bons materiais no mercado editorial para a Geografia. Portanto, podem e devem ser utilizados como fontes de consulta para atividades diversas nessa disciplina. Tanto pelo professor, ao preparar suas aulas, uma vez que é esse o material que o aluno terá disponível na escola na maioria das vezes, como pelos

\footnotetext{
${ }^{33}$ Artigo de Fernanda Padovesi Fonseca sobre Atlas escolares, não publicado mas trabalhado como texto complementar em aula de graduação em 04/2006 no Centro Universitário FIEO - UNIFIEO em Osasco, São Paulo.
} 
próprios alunos, durante as aulas, para leitura de textos complementares, por exemplo, ou mesmo em pesquisas para eventuais trabalhos.

O que se quer ressaltar neste momento é que o professor não deve deixar de ter um olhar crítico sobre todo o material didático com o qual pretenda trabalhar. É o que se procura fazer ao trabalhar com os materiais didáticos fornecidos pelo governo estadual de São Paulo.

Conforme observa J. Gimeno Sacristán já que esses materiais são pensados por outros autores, não seria o caso de os professores de Geografia construir seus próprios mapas e atividades adequadas para cada grupo de alunos tendo esses materiais prontos apenas como apoio?

Se, como coloca Fernanda Padovesi Fonseca, se admite que no atlas geográfico escolar o mapa temático é uma constante, é preciso refletir se ele poderia ser entendido pelos alunos. Eles conheceriam a linguagem dos mapas se o professor não pensasse atividades de leitura, construção e interpretação desses mapas? Nesse sentido não caberia ao professor pensar atividades sobre e com a linguagem dos mapas? Aqui entra a proposta da atividade com a construção dos mapas, que é o exercício que se realizará na pesquisa junto com o ensino das regras da gramática da representação gráfica. E neste caso, seguindo a orientação de Lívia de Oliveira (Cf. Oliveira, 2008, p.23), o professor saberia exatamente qual objetivo alcançar por intermédio da realização das atividades propostas.

J. Gimeno Sacristán (1991) coloca que: "A prática profissional depende de decisões individuais, mas rege-se por normas coletivas adotadas por outros professores e por regulações organizacionais" (SACRISTÁN, 1991, p. 71).

A autonomia do profissional da educação diretamente ligado à sala de aula pressupõe decisões individuais. Como já afirmado o professor deve exercer a sua capacidade de análise crítica durante suas escolhas no momento de seleção dos materiais e conteúdos que levará para os seus alunos.

Todavia, o que se pretende destacar aqui, é que se concorda com José Carlos Libâneo, quando cita Davydov: Davydov recrimina no ensino tradicional a transmissão direta aos alunos dos produtos finais da investigação, sem que possam aprender a investigar por si mesmas [...] (LIBÂNEO, 2004, p. 19).

Diante do exposto seria conveniente que nas atividades propostas com mapas em sala de aula os alunos construíssem os mapas por intermédio da consulta de tabelas. Como é evidenciado no trabalho de Jacques Bertin e Roberto 
Gimeno (BERTIN e GIMENO, 1982). Seria o caso de entender que a investigação mencionada pode ser considerada na busca que os alunos farão sobre quais variáveis visuais serão mais adequadas para a representação dos fenômenos que se desejar espacializar e que faz parte da atividade que é proposta? E que a tabela é que permitirá a seleção das variáveis visuais e a sua espacialização para a visualização do fenômeno em questão? Pensa-se que sim, pois, durante as atividades haverá uma ação investigativa, que poderá, dependendo da série onde se quiser trabalhá-la, por exemplo, nas últimas séries/anos do ensino fundamental, ser ampliada para a pesquisa do fenômeno em si, inclusive. Por exemplo, num mapa que trate de importação e exportação poder-se-ia levar os alunos a pesquisarem sobre os dados e os países com os quais o Brasil possui relações comerciais. Qual seria o nível de dependência exercida nessas relações? Estas poderiam ser algumas questões levantadas a partir da construção do mapa, para depois poder analisar a sua espacialidade.

Neste caso o mapa seria o ponto de partida do ensino tanto da Cartografia como da Geografia. No exercício que se pretende aplicar, que demandará apenas algumas aulas, não será possível aprofundar com os alunos a história da cartografia, ou a sugestão feita acima. Todavia será possível apresentar uma breve síntese do uso dos mapas ao longo da história. Mas não seria o caso de se pensar em aplicar uma breve história da cartografia nas aulas de Geografia no ensino fundamental ao se pensar sobre as orientações dos autores? O que se sugere não é apenas ensinar o mapa, mas como entender os conceitos geográficos e as relações entre os objetos e ações que são o espaço geográfico, por meio dos mapas produzidos, e da leitura e interpretação dos mapas que devem estar nas aulas de Geografia mais comumente.

Todo o procedimento metodológico esboçado corrobora para evidenciar a responsabilidade do professor, que é a colocação anterior de Paulo Freire (1996) sobre a formação científica e a de Lana Cavalcanti ${ }^{34}$ quando afirma que "A Geografia escolar é o conhecimento geográfico efetivamente ensinado". Portanto é preciso aceitar que o conhecimento que o professor traz da academia não é o que deve ser aplicado em sala de aula. $O$ ideal é pensar como, por meio da relação

\footnotetext{
${ }^{34}$ Lana Cavalcanti da Universidade Federal de Goiás em mesa redonda do dia 14/08/2008 no Seminário Internacional de Geografia e Ciências, na Faculdade de Educação da USP, que ocorreu de 13 a 15 de agosto de 2008 .
} 
dialética, entre conhecimento acadêmico e prática educativa, determinadas atividades levarão os alunos à aquisição de conhecimentos geográficos.

Quem traz esta observação é Davydov:

O procedimento prático de se realizar essas estratégias são as ações de aprendizagem. Por meio de atividades de abstração e generalização e exercícios escolares, representativos da disciplina, pode-se ensinar às crianças o modo como aprender a manejar seus processos cognitivos. (DAVYDOV, apud LIBÂNEO, 2004, p. 19).

\title{
2.2 A aprendizagem
}

A partir das proposições de Vygotsky seria possível compreender os processos de formação da mente, num contexto social.

\begin{abstract}
O social constitui, por um lado, a fonte do desenvolvimento conceitual da criança e caracteriza, por outro lado, a organização da atividade comum e do aprendizado do aluno. Em sua primeira acepção, o desenvolvimento da criança surge ao mesmo tempo como resultado de sua imersão em um ambiente cultural e como o próprio processo de apropriação que ela faz desse meio. [...] Em sua segunda acepção, o social encontra-se vinculado à atividade, de maneira que a criança somente pode apropriar-se do ambiente cultural enquanto ser ativo. [...] necessária a inclusão do outro na atividade da criança, outro que já tenha experiência no uso desses objetos como instrumentos e produtos do ambiente cultural. A atividade realizada em comum com adultos ou crianças mais velhas, através de um processo de interiorização, alcançará, segundo Vygotsky (1956), o domínio individual de seu próprio pensamento. (GARNIER, et al,1996, p.12-13).
\end{abstract}

Sendo assim, seria de pressupor que os exercícios propostos para a verificação da aplicabilidade das variáveis visuais na construção de mapas com uma linguagem visual adequada ao ensino de Geografia deveriam seguir este princípio. É o que se pretende.

É Pilar Lacasa que escreve sobre os mecanismos de aprendizagem e relações sociais e pode colaborar na interpretação das atividades. A autora afirma que há estudos que comprovam que as atividades em grupo podem ser consideradas positivas para a aprendizagem à medida que os alunos terão que propor soluções, apresentá-las e justificá-las, inclusive aos demais colegas do grupo. Assim todos terão que discutir sobre as possiblidades de aplicação do que foi sugerido inicialmente e juntos poderão aceitar ou recusar a proposta inicial (tradução nossa) (Cf. Lacasa, 1994, p.306-310). Mas, será positiva apenas se o professor observar que, de fato, ocorre interação entre os elementos do grupo na proposta de soluções. 
Cabe também ao professor de Geografia pensar que tipo de material didático leva para a sua sala de aula tem que ter em mente que esse material venha colaborar para o desenvolvimento de atividades entendidas de necessidade de um sujeito. Necessidade de intervir, de participar, de propor soluções. A sugestão do exercício de construção de mapas nas aulas de Geografia trarão necessidades que devem ser atendidas. Por exemplo, quais variáveis visuais selecionar para a representação? Ou ainda, como ordenar os elementos da tabela para formar depois, uma imagem? Mas, cabe ao professor verificar se todos estão participando.

Como visto anteriormente, os mapas temáticos estão frequentemente presentes nos materiais utilizados em sala de aula. O que não é óbvio é se eles são ensinados, ou mesmo se realmente há a sua utilização em processos de aprendizagem na disciplina de Geografia. Qual seria então a necessidade, para os alunos, de trabalharem com mapas? Como deve o aluno pensar o mapa para entender a Geografia? Qual a finalidade do mapa em sala de aula? Ele seria utilizado como situação de aprendizagem pelo próprio professor?

Considera-se, nesta pesquisa, junto com Fernanda Padovesi Fonseca e Jaime Tadeu Oliva que a cartografia é um instrumento, que por apresentar-se como uma linguagem visual é facilitadora da aquisição de conhecimentos geográficos:

\begin{abstract}
Considerando que a percepção espacial e a linguagem gráfica e cartográfica (grifo dos autores) são trabalhadas desde o primeiro grau, e que esses são aspectos fundamentais na evolução das estruturas cognitivas e no crescimento intelectual das crianças e dos jovens adolescentes, diversas contribuições têm sido dadas no sentido de aprimorar o conhecimento nas áreas que lidam com a representação espacial. (FONSECA e OLIVA, 2002, p.70).
\end{abstract}

Sendo assim, a necessidade de atividades com mapas temáticos em aulas de Geografia surgem ao se observar que existe um arcabouço teórico fornecido pelo trabalho de Jacques Bertin sobre Semiologia gráfica, que permite a construção de mapas conforme a gramática da representação gráfica. Obedecendo a essa gramática poder-se-ia, por intermédio dos mapas construídos, alcançar a explicitação do espaço geográfico no contexto atual da disciplina de Geografia em um mundo globalizado ${ }^{35}$. Assim, ainda com os mesmos autores (FONSECA e OLIVA, 2002) afirma-se a importância da cartografia como linguagem, e nesse sentido, entende-se a atividade cartográfica, apresentada e construída como

\footnotetext{
${ }^{35}$ Marie-Françoise Durand, Geografia e relações internacionais: globalização, territórios e redes na perspectiva da escola geográfica francesa, Caderno $\mathrm{CRH}$, Salvador, v.19, n.48, p.431-444, set./dez.2006.
} 
linguagem visual, um importante instrumento para o desenvolvimento cognitivo dos alunos nas aulas de Geografia. Portanto facilitadora do ensino e da aprendizagem em Geografia.

Nesse sentido, não seria o caso de o professor de Geografia estar atento à sua prática e inserir o ensino da cartografia temática de acordo com a gramática da representação gráfica no dia-a-dia da sala de aula?

É necessário esclarecer que nesta pesquisa trata-se sobre a linguagem cartográfica direcionada à cartografia temática. Entende-se que elementos como título e legenda, por exemplo, devem ser ensinados, juntamente com as regras da gramática da representação gráfica. No entanto, se o mapa for construído com as variáveis visuais que formam a imagem, que são o tamanho e o valor, a construção da legenda não se mostraria secundária ou mesmo dispensável, já que a informação imediata é visual?

Os autores ainda colocam que a cartografia, se entendida como uma linguagem atemporal e espacial pode ser um instrumento de análise e de expressão de conhecimentos geográficos, podem favorecer o desenvolvimento do pensamento geográfico. No entanto, falam em uma dicotomia indesejável entre Geografia e linguagem cartográfica (FONSECA e OLIVA, 2002, p.69). Esta separação, ou dicotomia indesejável, é empiricamente visível em salas de aula de Geografia. Mas, não seria então o caso de considerar que a gramática da representação gráfica, sendo ensinada a partir do ensino fundamental, permitiria que os alunos desenvolvessem outras atividades durante a construção dos mapas, que também seriam umas atividades em si? Ou seja, que trouxessem necessidades de resolução de algum tipo de problema? Aprender a construir um mapa, Ihes possibilitaria aprender sobre a sua gramática, e entendendo o mapa, entender a Geografia. Seria possível evidenciar a forma (o mapa) e o conteúdo (o mapa e o os objetos e ações que ele representa). Entre essas atividades, seria possível que os alunos fizessem suas escolhas, discutissem entre si e resolvessem coletivamente como e qual será a melhor maneira de fazer a representação do fenômeno em questão. Sem falar na leitura e interpretação da tabela que é a fonte dos dados em sala de aula. Veem-se nessas sugestões várias oportunidades de aprendizagem, tanto cartográficas como geográficas, pois os alunos estariam se inserindo, por exemplo, nos conhecimentos geo-cartográficos na prática. 
Assim, entende-se que é urgente repensar sobre como utilizar a cartografia como linguagem na prática do ensino de Geografia no Brasil, pois o que é comum, no ensino fundamental, é que os mapas sejam subutilizados como afirma Lívia de Oliveira (OLIVEIRA, 2008, p. 9) o que também pode ser verificado empiricamente junto a alguns professores de Geografia.

Retoma-se, então, com a finalidade de justificar as sugestões apresentadas o conceito de atividade, agora com Flávia da Silva Ferreira Asbahr, e tem-se que:

[...] Esse conceito desempenha as funções de princípio explicativo dos processos psicológicos superiores e de objeto de investigação [...] Para Leontiev, tanto as atividades externas quanto as internas apresentam a mesma estrutura geral. A atividade interna é constituída a partir da atividade prática sensorial externa, ou seja, a forma primária fundamental da atividade é a forma externa, sensório prática, não apenas individual, mas fundamentalmente social (grifo nosso). A transformação da atividade externa em interna acontece por meio do processo de internalização. A passagem do externo para o interno dá lugar a uma forma específica de reflexo psíquico da realidade: a consciência. Leontiev define a consciência como conhecimento partilhado, como uma realização social. (ASBAHR, 2005, p.109-110).

Sendo assim, as atividades cartográficas serão mais bem desenvolvidas se os alunos trabalharem em grupo (BERTIN e GIMENO, 1982, p. 38-56), pois, o desenvolvimento da atividade coletiva leva ao desenvolvimento do indivíduo. As atividades sensório-práticas com mapas, desenvolvidas coletivamente, permitiriam a internalização pelo sujeito do objeto da ação, a construção do mapa, tornando-se consciente do processo, do mapear. O conhecimento poderá ser partilhado quando necessário. Vitaly Rubtsov a esse respeito também diz:

As pesquisas dos psicólogos mostraram que a aptidão para a aprendizagem é, na verdade, resultado de uma determinada interiorização, de maneira que a atividade de aprendizagem se apresenta, essencialmente, sob a forma de uma atividade realizada em comum, na qual as tarefas são repartidas entre os alunos, ou entre alunos e professor. (RUBTSOV, 1996, p. 134).

E aqui é evidente a importância do trabalho em grupo e da interferência do professor como facilitador de aquisição de conhecimentos geo-cartográficos.

Ao professor caberá apresentar a gramática da representação gráfica e pensar as atividades norteadoras dos trabalhos em grupo. A ação dos alunos na busca de construir mapas poderá se transformar em atividade de construção de mapas, em grupo. Nesse caso a atividade será então desencadeadora de um processo de aquisição de conhecimentos significativos para o ensino de Geografia como demonstrado por Jacques Bertin e Roberto Gimeno (1982), e neste caso não deveria estar presente em salas de aula dessa disciplina mais comumente? 
Nesse contexto se verifica o quanto é complexa a questão da prática no ensino, mas, e, portanto necessárias e urgentes, as discussões nesse âmbito para o exercício da profissão docente em Geografia.

Flávia da Silva Ferreira Asbahr fala que a "atividade interna é constituída a partir da atividade prática sensorial externa" (ASBAHR, 2005, p.109-110). Mas para realmente aprender como poderia ser efetivada a internalização de uma atividade sensório prática pelo aluno? Quais seriam as condições ideais para que ele desenvolva realmente atividades que o façam avançar? Neste caso, retoma-se a questão do contexto.

Nesse sentido, algumas questões vividas em sala de aula, no cotidiano escolar não podem ser resolvidas e mesmo ao colocar em prática todas as observações feitas pelos autores anteriormente mencionados ficaria em aberto um fato: a afetividade.

É nítida a questão da afetividade interferindo no processo de ensino e aprendizagem. Aurino Lima Ferreira afirma que:

podemos definir a afetividade como o domínio funcional que apresenta diferentes manifestações que irão se complexificando ao longo do desenvolvimento e que emergem de uma base eminentemente orgânica até alcançarem relações dinâmicas com a cognição, como pode ser visto nos sentimentos (FERREIRA et al, 2010, p.26).

O autor afirma que algumas situações entre elas precisam ser analisadas cuidadosamente. Ele deve ter uma atenção abrangente e integrativa do desenvolvimento. $\mathrm{O}$ autor salienta que o aluno, em suas diferentes faces enquanto pessoa deve tê-las todas contempladas, para que seja possível intervir. Olhar para esse aluno unilateralmente "privilegiaria apenas uma dimensão ou conjunto funcional” (FERREIRA e ACIOLY-RÉGNIER, 2010, p. 30). Portanto, desenvolvimento cognitivo e desenvolvimento afetivo caminham juntos em alguma medida, no período da educação formal.

Como visto anteriormente as discussões sobre desenvolvimento cognitivo não abarcaram a questão da afetividade. Esta é apresentada por Aurino Lima Ferreira ao trazer as concepções wallonianas para a educação. Segundo o autor "cognição e afetividade estão irremediavelmente presentes na formação da pessoa" (FERREIRA e ACIOLY-RÉGNIER, 2010, p.35). 
Sendo assim, seria possível pensar que parte do contexto dos alunos se manifesta em sala de aula em questões indisciplinares? E que a indisciplina seria, algumas vezes, de fato uma questão de afetividade se manifestando?

Paulo Freire afirma que precisamos prestar atenção até no silenciar dos alunos, ou mesmo num sair, retirar-se da sala de aula. Segundo o autor "o espaço pedagógico é um texto (grifo do autor) para ser constantemente `lido', interpretado, 'escrito' e 'reescrito' “" (FREIRE, 1996, p. 97).

Portanto a não compreensão do contexto de afetividade seria o que justificaria parte das questões sobre a defasagem que os alunos apresentam no ensino, inclusive?

\subsection{Professor: contexto de ação e formação, na prática educativa.}

Retomar o que Rita Simone Soares Vignoli traz a respeito da responsabilidade do professor com relação ao currículo parece ser conveniente para iniciar esta parte do trabalho. Como a autora salienta o professor em exercício é que, de fato, efetivará o currículo, e é atribuída naturalmente a ele essa responsabilidade (VIGNOLI, 2003, p.44).

Segundo pesquisa publicada pela UNESCO as últimas décadas vêm sendo dedicadas à procura de mudanças para e pela educação no Brasil, assim como se observa em várias partes do mundo. Aponta, no entanto, resultados não satisfatórios quando o quesito é o desempenho de aprendizagem dos alunos. "As medições nacionais e internacionais confirmam que os progressos são muito lentos e que existem desigualdades muito significativas nos resultados de aprendizagem dos alunos de diferentes origens sociais" (UNESCO, 2004, p. 11). E, embora afirme que o êxito da aprendizagem é resultado de diversos e complexos fatores, destaca a importância do que denomina "fator docente": "entendido como o conjunto de variáveis que definem o desempenho dos mestres, professores e diretores das escolas: condições e modelos de organização do trabalho, formação, carreira, atitudes, representações e valores" (UNESCO, 2004, p. 11). 
Neste sentido algumas considerações feitas por J. Gimeno Sacristán (SACRISTÁN, 1991) ${ }^{36}$ são necessárias.

Para J. Gimeno Sacristán haveria na educação uma continuidade em como criar os filhos e nas relações sociais Portanto, vê-se com nitidez que a educação, embora também se desenvolva na escola, não é unicamente nela que se concretizará. A escolarização seria apenas uma parcela no contexto educativo na vida dos indivíduos, que acontece em conjunto e continuamente a outros contextos.

No contexto da educação formal, empiricamente, inclusive, é possível divisar que se tem a figura do professor entendida contemporaneamente como o principal fator para o desenvolvimento ideal do ensino. Embora as pedagogias modernas concentrem-se na aprendizagem, e assim tenha-se como elemento principal o aluno (Cf. Amaral, 2010, p. 27), a pesquisa mencionada revela que o professor ainda é tido como o foco central no processo de ensino aprendizagem no Brasil: "pois são eles [mestres e professores] os atores fundamentais das transformações educacionais destinadas a oferecer uma educação de boa qualidade para todos" (UNESCO, 2004, p. 12). José Gimeno Sacristán chega a falar numa hiperresponsabilização do professor. E entende-se que a formação do professor é uma questão polêmica em vários sentidos e a profissionalidade docente também.

A profissionalidade docente configura-se como "o conjunto de comportamentos, conhecimentos, destrezas, atitudes e valores que constituem a especificidade de ser professor" (SACRISTÁN, 1991, p. 65). Neste caso, afirma o autor, o conceito está em constante mudança, pois está arraigado àquela realidade social que deve ser legitimada pelo conhecimento escolar. Assim, a imagem da profissionalidade ideal está também subjugada a certos valores, ao currículo, a práticas metodológicas ou às avaliações necessárias para determinado momento histórico. Esta observação torna-se evidente ao se retomar as discussões sobre o percurso da educação no Brasil. Em cada momento histórico, evidencia-se uma necessidade específica. A atual, para o Estado de São Paulo é o desenvolvimento de habilidades e competências, com uma base curricular comum a todas as escolas públicas da rede estadual e que serão cobradas em avaliações externas. E esta é

${ }^{36}$ Parte das considerações feitas são embasadas em J. Gimeno Sacristán, conforme segue: SACRISTÁN, José Gimeno. Consciência e ação sobre a prática como libertação profissional dos professores. In Nóvoa, A. (org.) Profissão Professor. Porto, Porto Editora, 1991, p. 63-90. 
uma mudança recente, pois implementada em 2008, à qual há a necessidade de adaptação dos professores. O que se espera dos professores para a educação do século XXI, é ainda uma incerteza? Milton Santos, afirma que há uma violência da informação frente ao processo de globalização contemporâneo e denomina-a como tirania da informação (Cf. Santos, 2001, p.35) . O fato é que com a quantidade de informações disponíveis instantaneamente, qual deverá ser o papel da escola para os alunos que vivenciam este século? Qual será o conhecimento que lhes permitirá inserir-se no cotidiano como cidadãos de fato?

Ainda, é preciso considerar o conceito de qualidade na educação como sendo determinado por grupos sociais e valores dominantes nas distintas áreas do conhecimento educativo. Portanto, ao professor caberiam adequações às necessidades que emergirem. Hoje então, educação de qualidade na rede pública do estado de São Paulo, seria aquela onde o professor, em sua prática cotidiana, levasse o aluno ao desenvolvimento de habilidades e competências. Mas, ao se pensar na teoria da atividade como motor para o desenvolvimento de habilidades e competências, não estaria o professor também envolto na necessidade de contínuo pensamento e ação para aprender?

Para entender a prática específica do professor, considerando-se que ele deveria dominá-la, a questão que o autor coloca é: "Será que os professores dominam a prática (grifo do autor) e o conhecimento especializado ao nível da educação e do ensino? Em termos gerais a resposta é negativa." (SACRISTÁN, 1991, p. 68). O que pode ser observado durante a pesquisa com relação ao trabalho docente com mapas em sala de aula, por exemplo, principalmente com relação à explicitação do espaço geográfico.

O autor ressalta que para entender a relação teoria-prática de modo mais geral, sob o enfoque da prática, é preciso falar sobre os esquemas práticos e afirma que os especialistas dominam a maioria deles. Esses esquemas não seriam formas de ação improvisadas, mas pensamentos que se configuram em ação embasados em teorias. Esses esquemas permitiriam aos professores realizar inúmeras atividades. Eles, inclusive extravasariam o tempo letivo. "Pois estão presentes em todas as funções que o professor realiza: ensino pré-ativo, interativo e pós-ativo" (JACKSON, 1975 apud SACRISTÁN, 1991, p.79).

Mas, José Gimeno Sacristán lembra que a prática educativa não é de responsabilidade exclusiva dos professores. Esta é compartilhada por todos os que 
estão envolvidos, por meio das práticas escolares, quer sejam institucionais ou políticas, dentro do que ele denomina práticas concorrentes. Todos estes agentes configuram o mundo educativo (SACRISTÁN, 1991, p.76).

Ainda que haja uma intencionalidade docente nesse sentido, que é o de dominar a prática, ocorrerá influências externas: políticas, econômicas, culturais, que interferirão sobre suas ações. O fato é que os professores não produzem aquilo que são chamados a reproduzir, nem são eles que irão determinar as estratégias práticas de ação. Livros, didáticos, cadernos do professor, apostilas, atlas escolares, e nem o currículo que deverão desenvolver, assim como outros materiais utilizados no exercício prático da profissão, não foram produzidos por eles, mas devem ser por eles utilizados. Daí a importância de análise do significado da prática educativa e também das consequências na formação docente.

Tomam-se por base as orientações do autor e coloca-se que, por exemplo, para o professor de Geografia, explicitar o objeto de estudo da disciplina em sua prática implicará: usos metodológicos; avaliações de níveis de desenvolvimento cognitivo dos alunos que permitiriam levar à aprendizagem que desencadearia o desenvolvimento de habilidades e competências das mais diversas; considerar o que seria mais significativo ensinar e considerar o contexto de seus alunos; demarcar normas de conduta em sala de aula, refletir sobre o valor social da disciplina, que deve ser evidenciado em aulas, sem perder de vista o currículo. Tudo isto configuraria a prática educativa da Geografia. "Tudo isto configura a prática, que é tudo isto ao mesmo tempo" (SACRISTÁN, 1991, p. 68). Assim, há dimensões menos evidentes na prática, nas atividades práticas dos professores que não apenas aquelas facilmente identificáveis no currículo. Explicitar o conceito de espaço geográfico, ou o de lugar, ou mesmo a globalização ou ainda as condições geomorfológicas de um determinado espaço, quer local, quer o espaço total, não está dissociado de outras questões, que no caso, não são exatamente do âmbito da Geografia. Por exemplo, conflitos pessoais, a afetividade, o racismo, o preconceito, o bullyng, a estrutura de organização escolar, estão inseridos de alguma maneira no contexto de sala de aula, mas também são resultado de interações sociais mais amplas, que formam os contextos extraclasse e além dos muros da escola. O autor se refere ao que ele chama de práticas aninhadas, concorrentes, que são demonstradas em seu sistema de práticas educativas aninhadas. Nesse sistema, a prática institucionalizada, aquela que exige o posto de trabalho, está posta como 
uma prática burocraticamente controlada, dando origem a um sistema de dependência dos profissionais, relativamente às diretrizes exteriores. Ao considerar o todo no qual está imerso o trabalho do professor, ele "é condicionado pelos sistemas educativos e pelas organizações escolares em que estão inseridos" (SACRISTÁN, 1991, p. 71). Seria possível e necessário trazer o fato de certo desconforto no exercício da profissão docente, frente às questões que emergem das condições postas. Nem sempre, as ideias apresentadas pelos professores no cotidiano são aceitas e aplicáveis. O sistema burocrático da educação inibe, muitas vezes, o trabalho docente. Surge desse contexto o que o autor chama de irreal autonomia do professor. $O$ fato é que esse profissional não responde por intermédio de ações meramente adaptáveis a situações herdadas. A excessiva dependência dos profissionais ao meio socialmente organizado, no qual desenvolvem seu trabalho manifesta-se em conflitos nos professores.

É preciso considerar seus contextos de desenvolvimento pessoal, e que na maioria das vezes, as exigências externas não coincidem com suas interpretações pessoais, inclusive. $O$ autor afirma que ainda assim há margens para a expressão da individualidade, embora restritas aos contextos pessoais.

O que seria importante considerar é que "o pensamento pragmático não pode ser considerado de qualidade inferior ao pensamento teórico" (SACRISTÁN, 1991, p. 83).

Segundo Sacristán, dentro da própria escola podem ser destacadas práticas que interferem e agem em conjunto com a prática didática, esta sim, diretamente de responsabilidade do professor, a saber: a) práticas institucionais, ligadas ao funcionamento do sistema escolar e configuradas pela sua estrutura; b) práticas organizativas, relacionadas ao funcionamento da escola e configuradas pela sua organização; e finalmente as práticas didáticas.

Por exemplo, com relação às práticas institucionais está a questão das avaliações externas, no caso do estado de São Paulo, o Saresp, e para todo o Brasil, o ENEM. Em se tratando das práticas organizativas poder-se-ia mencionar a forma de trabalho dos professores, se trabalham em conjunto ou individualmente, considerando a articulação de saberes e disciplinas ou não, e a gestão de tempo e do espaço escolar. Os aspectos surgidos devido a essas interferências incidem sobre a realidade escolar imediata. 
O autor afirma que em contraponto ao sistema burocraticamente organizado, é possível ainda identificar zonas de desorganização.

Destaca, inclusive, que os espaços escolares não se limitam a transmitir cultura para os alunos e para os professores, mas também contribuem para a recriação destas culturas.

Segundo o autor as atividades de educar e ensinar, assim como a cultura que as rodeia, são de constituição social, distribuída socialmente, e não se encontram limitadas a um só grupo profissional. A profissão docente é compartilhada socialmente, deriva daí sua dimensão conflituosa e pode, inclusive, ser considerada uma semiprofissão. E acrescente-se ao fato que "a escola apresenta-se muitas vezes obsoleta aos olhos de agentes e forças culturais que necessitam de uma outra educação e que, portanto, tendem a por em causa a legitimidade dos professores" (SACRISTÁN, 1991, p. 71), (grifo do autor). Considerar-se-ia então que o que o autor entende por prática, embasada nas teorias existentes e resultando em esquemas práticos de ação não estariam, necessariamente, atrelados à prática. $O$ papel que o docente ocupa na prática é o que é definido por ele, e não a prática em si. Observar-se-ia então que dependendo do posicionamento adotado pelo professor com relação aos contextos cotidianos de sua atividade, o que se entende por prática, seriam apenas adaptações gerais, que talvez não estejam ligadas a teorias específicas. Existiria nesse sentido uma grande "dificuldade em se comunicar aos professores o conhecimento prático estratégico" (SACRISTÁN, 1991, P.83). Existe um componente que merece destaque nesse sentido, que é a capacidade formal dos professores. Só o exercício desse componente permitiria a articulação satisfatória de ideias e práticas.

O autor ainda destaca algumas consequências de se observar o conteúdo da profissionalidade docente por intermédio da análise das práticas aninhadas entre as quais: 1) repercussão do conhecimento considerado como base da prática educativa, onde há que se considerar o que realmente é o conhecimento legítimo em educação, direcionando ao desenvolvimento de novos processos de formação; neste caso, qual seria o conhecimento legítimo em Geografia para a educação básica? 2) responsabilidade dos professores na prática; relativizar a ênfase dada ao papel do professor na determinação da prática e dos efeitos educativos: a questão é que se há determinações externas das práticas, mas, se elas forem atribuídas à iniciativa dos professores, sua externalidade torna-se menos evidente. E ainda, 3) 
amplitude da profissionalidade, nesse quesito o professor deveria intervir em todos os domínios que influenciam a prática docente, onde:

A imagem libertadora do professor investigador (grifo do autor) deve aplicarse ao conjunto do trabalho docente, e não apenas à atividade pedagógica na sala de aula. É preciso enfrentar as questões do poder (grifo nosso) na educação, não aceitando uma limitação do papel dos professores aos aspectos didáticos. (SACRISTÀN, 1991, p.75).

No item 4) Uma profissão confusa, questiona quais seriam as competências do professor, à medida que a ampliação do âmbito da profissionalidade dilui o seu conteúdo. 5) complexidade das reformas educativas: torna-se relevante considerar que mudanças e inovações são temas complexos. Nesse sentido o autor resgata $\mathrm{H}$. Giroux que recusa a presença de programas pontuais de formação, e pressupõe o "resgate da imagem do professor como intelectual" (GIROUX, 1985, apud SACRISTÁN, 1991, p. 76); 6) e o poder sobre a prática. O próprio J. Gimeno Sacristán afirma ser evidente:

\footnotetext{
que o 'educativo' obedece a lógicas que não se esgotam num conhecimento formalizado sobre a educação, é evidente que os caminhos da mudança são muito diversos e complexos".[...] Ações e programas de formação têm de incidir, nos contextos em que a prática se configura e em que se produzem determinações para as iniciativas dos professores.[...] Trata-se de um programa com, pelo menos, quatro grandes campos:

- O professor e a melhoria, ou a mudança, das condições de aprendizagem e das relações sociais da sala de aula.

- O professor participando ativamente do desenvolvimento curricular, deixando de ser um mero consumidor.

- O professor participando e alterando as condições da escola.

- O professor participando na mudança do contexto extra-escolar. (SACRISTÁN, 1991, p. 77).
}

A relevância de um conhecimento que se observa em relação à prática é muito diferente, dependendo das situações em questão. Poder-se-ia afirmar que o apoio fornecido pela teoria à prática é precário, seria limitado o fecundar da prática pela teoria. O que resultaria na ação dos professores mais vinculada a mecanismos de ação adquiridos culturalmente por intermédio da socialização, onde o conhecimento pedagógico teria um papel menos relevante.

O autor afirma que a análise da educação como prática que se desenvolve em contextos reais, carregada de interpretações e de intenções subjetivas, e construída por diversos atores que se reflete em usos de natureza prática, seria mais conveniente para a discussão. Neste caso, seria então, refletir sobre o papel 
ativo e intelectual dos professores e a própria ligação entre teoria e investigação, entre pensamento e ação.

Observar atentamente os esquemas estratégicos possibilitaria definir com clareza a componente intelectual do exercício da profissão docente.

Para Sykes:

\begin{abstract}
'Para levar a cabo uma atividade docente, de forma efetiva, o prático deve desenvolver não só a capacidade de atuar - o emprego de aptidões técnicas no seu desempenho - mas deve também avaliar as consequências de suas ações, considerar desenvolvimentos alternativos da ação, colocar e resolver problemas idiossincráticos e recorrentes, e utilizar uma série de marcos conceituais neste processo cognitivo e interativo' (SYKES, 1986, p. 230 apud SACRISTÁN, 1991, p. 83).
\end{abstract}

José Gimeno Sacristán chama o professor de "gestor de dilemas" . E afirma que esses dilemas são inúmeros e frequentes, o que lhe tornaria difícil "acompanhar na prática as exigências morais e técnicas do ensino" (SACRISTÁN, 1991, p. 86). Esclarece que:

\footnotetext{
Esta definição do ensino como tarefa problemática, do ponto de vista intelectual e moral, é de alguma transcendência para os professores e para a concepção de sua formação, porque é o que é o que marca o fato de pertencerem a uma profissão, em vez de serem meros funcionários ou técnicos. (SACRISTÁN, 1991, p. 86).
}

Neste caso, o compromisso intelectual, ético e social dos professores é realçado. A questão é que se está imerso num mundo dividido e controverso. E o autor afirma que haveria então uma significação coerente com o que ele chama de "insegurança epistemológica, por falta de apoios imediatos do conhecimento dito científico com que se concebe a própria atividade de ensinar" (SACRISTÁN, 1991, p.86). O autor reafirma a necessidade de mudanças e adaptações no quesito formação de professores, que poderiam aprimorar muito "a capacidade operativa do conhecimento e da investigação pedagógica na prática" (SACRISTÁN, 1991, p.87).

E no caso da Geografia, Rosalina Batista Braga destaca o papel do professor, entendido como mediador no processo de ensino e aprendizagem e afirma que:

As novas demandas somadas a grandes desafios que a educação geográfica tem tentado equacionar, nas ultimas décadas, originam tensões no universo das práticas de ensino e de formação de seus profissionais. (BRAGA, 2010, p. 365). 
Esse mundo, mencionado e adjetivado por J. Gimeno Sacristán, que configura a realidade dos alunos deverá ser esclarecido pela Geografia escolar. A multiplicidade de dados, culturas e contextos de acesso generalizado, possibilitados pela globalização e disponíveis nas redes informacionais devem poder ser analisados criticamente. A criticidade deve estar presente nas atividades do professor, que deve também direcionar os seus alunos ao desenvolvimento de habilidades e competências para discernir as informações.

Ao considerar as atividades profissionais do docente, retomam-se as posições teóricas da psicologia histórico-cultural, de Vygostsky e da teoria da atividade, de Leontiev. Poder-se-ia considerar que para "VYGOTSKY a consciência era mediada pela cultura, para LEONTIEV a mente e a consciência eram mediadas por ferramentas e objetos" (ZINCHENKO, 1998, p. 44, apud LIBÂNEO, 2004, p. 118). Assim, deve-se considerar tanto a cultura quanto $o$ acesso às ferramentas culturais e a ação sobre elas para alcançar níveis diferentes de desenvolvimento cognitivo. Sendo assim, como seriam pensados os cursos de formação de professores? Quais seriam as atividades desenvolvidas pelos futuros professores, no momento de sua graduação?

Rosalina Batista Braga fala da formação inicial e continuada de professores que deveria ser mais adequada ao que ela denomina de novas demandas. O fato é que o contexto da formação profissional será refletido nas situações vividas em sala de aula. A questão aqui é que o professor será o responsável por levar aos alunos os meios favoráveis para a transformação do conhecimento que o aluno traz consigo, em conhecimento institucionalizado e ir além dele, durante o processo educativo, pelo menos. Se como afirma a autora, o professor não tiver tido uma formação inicial em sintonia com as novas exigências, certamente haverá tensões, e principalmente no universo das práticas de ensino.

Especificamente com relação à Geografia, Lívia de Oliveira afirma a necessidade de uma Cartografia escolar nos currículos de formação de professores (OLIVEIRA, 2008, p.24 ). Embora a autora não use literalmente o termo Cartografia geográfica, não seria conveniente que os professores de Geografia fossem preparados para ensinar utilizando uma cartografia explicativa do espaço geográfico? Uma cartografia mais cognitiva?

Ainda com Paulo Freire é possível afirmar que: 
Não posso ser professor sem me achar capacitado para ensinar certo e bem os conteúdos de minha disciplina, não posso, por outro lado, reduzir minha prática docente ao puro ensino daqueles conteúdos. Esse é um momento apenas de minha prática pedagógica. Tão importante quanto ele, o ensino dos conteúdos [...] é a preparação científica revelada sem arrogância, pelo contrário, com humildade. É o respeito jamais negado ao educando, ao seu saber de 'experiência feito' que busco superar com ele. (FREIRE, 1996, p. 103).

Entende-se que certamente a formação inicial do professor é significativa, assim como a formação continuada desse profissional em benefício da qualidade do ensino. Este fato é observável empiricamente, inclusive.

Helena Copetti Callai diz que o conceito de educação geográfica está em construção e diz respeito a mais do que ensinar e aprender geografia. "o sujeito pode construir as bases de sua inserção no mundo em que vive, e, compreender a dinâmica do mesmo através do entendimento da sua espacialidade" (CALLAI, 2010, p.413). A autora destaca o papel do processo de globalização da sociedade e da mundialização da economia para alcançar esse entendimento, o que faz surgir a necessidade de novas ferramentas no processo educativo. Mas, os professores em exercício teriam acesso a essas novas ferramentas para o ensino? Quais seriam essas ferramentas para a efetivação do processo de ensino e aprendizagem em Geografia? A mesma autora aponta para a presença de pesquisas e trabalhos em andamento que direcionam a formação de professores na busca de uma educação geográfica. No entanto, existem profissionais em exercício, que procuram, e inclusive necessitam de uma formação continuada.

Nessa mesma direção, e aceitando-se a necessidade de uma formação que possibilite não apenas uma habilitação para o exercício docente, mas para 0 exercício efetivo de uma educação geográfica, não seria o caso de se pensar sobre o mapa, sobre a linguagem cartográfica como mais um recurso para a efetivação dessa educação na formação de professores? Fernanda Padovesi Fonseca afirma as possibilidades de se trabalhar com mapas mais cognitivos no ensino e enfatiza a incompatibilidade na métrica euclidiana para a representação do espaço geográfico na contemporaneidade (FONSECA, 2004, p. 214). Sendo assim, na busca de uma educação geográfica não seria o caso de se pensar em trabalhos direcionados para as possibilidades de utilização de outras métricas no ensino, como se propõe nesta pesquisa? 
Nesse sentido, como o professor vê a Geografia, como entende seu objeto de estudo, quais métodos e teorias são utilizados em sua prática, serão significativos para o processo de ensino e aprendizagem, ou não.

Segundo Paulo Freire "ensinar exige segurança, competência profissional e generosidade [...] a incompetência profissional desqualifica a autoridade do professor" (FREIRE, 1996, p.91-92). E neste caso, a formação do professor não deveria contemplar a aquisição de conhecimentos sobre a linguagem cartográfica regida pela Semiologia gráfica em prol do ensino de Geografia, uma vez que os alunos têm acesso aos mais diversos tipos de mapas, quer na mídia de um modo geral, quer nos materiais didáticos com os quais se depara na escola? O professor não deveria conhecer essa linguagem? Não se resolveria assim parte do que J. Gimeno Sacristán menciona sobre o apoio necessário do conhecimento científico imediatamente às necessárias resoluções de problemas imediatos que o professor tem que solucionar?

Mas como seria a grade curricular de licenciatura em Geografia? Ela estaria estruturada para a aquisição de conhecimentos geo-cartográficos?

$\mathrm{E}$ neste ponto, entende-se que para concluir esta parte do trabalho, as observações de José Carlos Libâneo são essenciais:

\begin{abstract}
Há, certamente, professores com bom nível de competências e habilidades profissionais, social e eticamente comprometidos com seu trabalho. Entretanto, as deficiências de formação inicial e a insuficiente oferta de formação continuada, aliadas a outros fatores desestimulantes, têm resultado num grande contingente de professores mal preparados para as exigências mínimas da profissão (domínio dos conteúdos, sólida cultura geral, domínio dos procedimentos de docência, bom senso pedagógico). Há dificuldades dos professores em lidar com novos problemas sociais e psicológicos que acompanham os alunos que entram na escola (familiares, de saúde, de comportamento social, concorrência dos meios de comunicação, desemprego, migração...). Mais uma vez, não se trata de culpabilizar os professores, eles não respondem sozinhos pelos fracassos da escola, atrás deles estão as políticas educacionais, os baixos salários, a formação profissional insuficiente, a falta de condições de trabalho, falta de estrutura de coordenação e acompanhamento pedagógico etc. Mas para quem gostaria de ver as crianças e jovens aprendendo cidadania, dominando conceitos das disciplinas escolares, desenvolvendo seus processos e habilidades de pensamento... não há como não se decepcionar com os resultados apresentados. (LIBÂNEO, 2004, apud UNESCO, 2004, p.170).
\end{abstract}

E o que se pretende com as atividades com mapas em Geografia, é permitir que os alunos adquiram novos conhecimentos tanto em Geografia como em cartografia por meio de uma cartografia geográfica e deixar a decepção para trás. 


\section{A TEORIA NA PRÁTICA:}

Atividades cartográficas e os conhecimentos geo-cartográficos.

As atividades aplicadas, que incluem os procedimentos didático pedagógicos, os exercícios, assim como a opção de formação de grupos ou trabalho individual; a exposição dos temas dos mapas e a correlação feita entre os mapas produzidos e os temas discutidos, foram orientadas por teorias pedagógicas, geográficas e cartográficas.

Mas, e inclusive, pensou-se que seria conveniente buscar também algumas informações que explicassem o que se vê (atitudes e procedimentos tanto dos alunos como de minha parte) no cotidiano escolar, durante a parte prática da pesquisa.

A professora Helena Copetti Callai colabora para esta observação ao afirmar que o professor deve conhecer a sua ciência e seus fundamentos teóricos, mas, inclusive saber o significado do aprender. Questões ligadas ao aprendizado, e mesmo se ele ocorre; o modo como os alunos se portam e como interagem entre si e comigo; como lidam com essa Geografia que Ihes é apresentada por intermédio da construção e leitura de mapas. E mais ainda, o fato de eles mesmos terem que construir seus mapas e não trabalharem com mapas dos Atlas geográficos ou dos livros didáticos, são condições novas para eles. Esta é mesmo a proposta do trabalho, e os exercícios escolhidos para aplicação em sala de aula têm mesmo essa função: Permitir refletir sobre a teoria na prática.

\footnotetext{
A ligação teoria/prática, no caso da formação do professor, deve ter a perspectiva do pedagógico, do educador e da ciência com que se está trabalhando, para não cair no conteudismo, ou em uma capa metodológica sem conteúdo (CALLAI, 2002, p.256).
}

Um reforço para esta concepção vem com as colocações de Antônio Nóvoa que reafirma a necessidade de reflexão sobre a própria prática. Destaca inclusive que a formação de professores tem, obrigatoriamente, que ter forte presença da prática. Afirma que ela deve ser centrada na aprendizagem dos alunos, observandose casos concretos. $\mathrm{O}$ que se pretendeu fazer nesta pesquisa. $\mathrm{O}$ mesmo autor faz 
uma crítica ao simples acúmulo por professores, de cursos, conhecimentos ou técnicas. Para ele, o professor se constrói e reconstrói constantemente, no que ele chama de reflexividade crítica. E nesse caso destaca a importância da valorização da experiência profissional.

A formação não se constrói por acumulação (de cursos, de conhecimentos
ou de técnicas), mas sim através de um trabalho de reflexividade crítica
sobre as práticas e de (re)construção permanente de uma identidade
pessoal (NÓVOA, 1992, p.25).

Não se tem a pretensão aqui de afirmar que os cursos, a aquisição de conhecimentos ou de técnicas não sejam necessários para a formação continuada de professores, ao contrário. Todavia, esses de nada adiantarão se o professor não utilizá-los para refletir sobre a sua própria prática.

E assim, tendo como norte a reflexão, a atividade prática de aplicação da gramática da representação gráfica para a construção de mapas sob uma linguagem visual proposta nesta pesquisa, levou em consideração os resultados obtidos na atividade diagnóstica, também no transcorrer das aulas expositivas, nas atividades realizadas pelos alunos e na análise posterior dos mapas resultantes. Portanto, entende-se que faz parte da reflexão, para a formação continuada de professores, a observação de todos os procedimentos envolvidos no processo de ensino e de aprendizagem.

Paulo Freire cita a condição de inacabado. Para o autor a certeza do inacabado, da consciência desse inacabamento é que tornaria ético o ser, de opção, de decisão. O professor, consciente de seu inacabamento, em sua prática deve falar com o outro, e entende-se que o outro tem várias maneiras de expressar sua fala, que não apenas verbalmente.

[...] Não é falando aos outros, de cima para baixo, sobretudo, como se fôssemos os portadores da verdade e ser transmitida aos demais, que aprendemos a escutar, mas é escutando que aprendemos a falar com eles. Somente quem escuta paciente e criticamente o outro, fala com ele, mesmo que, em certas condições, precise de falar a ele (FREIRE, 1996, p. 113).

Por este motivo, procurou-se estar atento a procedimentos e atitudes dos alunos envolvidos na parte prática da pesquisa. Falar com eles sobre o que viam ou não; entender o que precisava ser melhorado; quais as dificuldades trazidas por eles e que não foram sanadas durante o período de escolarização, quer no ensino regular, quer na Educação de Jovens e Adultos (EJA). O fato é que estas dificuldades se apresentam durante as tarefas e na aquisição de novos 
conhecimentos. Todas as observações permitiram um diálogo com eles, cada um em sua linguagem mais apropriada, tanto à faixa etária como, principalmente, em relação a estarem no ensino regular ou na suplência.

Pensa-se que é conveniente neste momento destacar o que levou a escolha dos temas dos mapas, além da escolha do fundo de mapa com a regionalização do Brasil, pelo motivo de ser conteúdo de 6ª série no momento da aplicação inicial da pesquisa. A questão da indisciplina deu a ideia de que os alunos deveriam saber sobre as condições de vida de crianças e adolescentes de sua faixa etária por região, para poder comparar sua própria condição e privilégio ao acesso à educação e ao fato de apenas estudar. Sendo assim, decidiu-se trabalhar com mapas que mostrassem o trabalho infantil e o rendimento mensal das crianças e adolescentes por todo o Brasil. Considerou-se também que seria conveniente apresentar dados sobre a urbanização do país, para poderem correlacionar todos os dados. Em contrapartida foi feita uma tentativa de mostrar a quantidade de exportação e importação brasileiras e a porcentagem de exportação por região no Brasil. Os temas foram discutidos individualmente e depois se procurou fazer uma correlação das informações, na tentativa de evidenciar as desigualdades de distribuição de renda no país.

Neste sentido considera-se que o professor de Geografia tem em mãos uma disciplina fascinante, com um objeto de estudo, o espaço geográfico, complexo, mas nem por isso difícil de ser explicado. A realidade o explica, ele é vivido pelas pessoas, elas o constroem. Todas são construtoras, direta ou indiretamente, tanto dos sistemas de ações como dos sistemas de objetos que configuram o espaço geográfico (Cf. Santos, 2008, p. 83), no entanto, não se dão conta disso. E, cabe à Geografia escolar, até o ponto possível, adequado ao nível de ensino, tornar objetiva, clara, a intencionalidade do ser humano na construção e refuncionalização constante desse espaço. Portanto, o professor de Geografia deve ter claro para si de que maneira a Geografia escolar pode operar nessa direção. Quais as práticas de ensino que possibilitariam alcançar esse objetivo? Qual a sua concepção de Geografia? E ainda, ter consciência se essa sua concepção, seria/estaria coerente com o espaço vivido pelos seus alunos.

Jaime Tadeu Oliva afirma que essa deveria ser a premissa de uma Geografia renovada no ensino. Se o professor assume uma postura de levar para a sua prática uma educação como valor ele estará atuando na formação ampla do 
indivíduo, na "formação de atitudes, como elemento de inserção do indivíduo no universo cultural e de conhecimento humano [...] A educação como valor, por fim, nos faz acreditar que somos os sujeitos da história" (OLIVA, 2002, p.48-49).

Sendo assim, as questões que permearam esta pesquisa como um todo, se caracterizam em uma tentativa de uma Geografia escolar renovada e de valor social. Pois se pretendeu evidenciar uma prática de ensino que permitisse ao aluno ampliar seus conhecimentos de mundo por meio da possibilidade de ler e construir mapas nas aulas de Geografia. Assim, ele poderia reconhecer-se, e às suas ações, para a construção e refuncionalização do espaço geográfico, do seu espaço vivido ao longo da educação básica.

Portanto, as atividades práticas da pesquisa foram aplicadas a partir desses pressupostos, de duas maneiras:

1) Para a $6^{a}$ série e para a EJA utilizou-se uma avaliação diagnóstica (leitura de mapas), na sequência, aulas expositivas sobre a gramática da representação gráfica e atividades práticas de leitura e construção de mapas temáticos.

2) Para duas salas de $7^{\circ}$ ano foi proposto um desafio, onde os alunos teriam que descobrir e representar uma ordem visual utilizando os dados de uma tabela apresentada a eles, sem utilizar letras, números, sinais de $+/$ - ou $>/<$. Deveriam utilizar apenas o mapa base que receberam, lápis preto de escrever e borracha. Após os mapas prontos, a própria sala escolhe quais dos mapas produzidos mostram o que se pediu. Em seguida foram ministradas aulas sobre as variáveis visuais para dar sequência à aprendizagem.

\subsection{Lendo mapas para construir mapas}

Antônio Carlos Castrogiovanni ressalta a importância das atividades com mapas em sala de aula. Para esse autor, os alunos devem aprender a ler mapas, mas para tal há a necessidade do domínio das técnicas de representação, da linguagem dos mapas, e uma sensibilidade geográfica. Ainda destaca a presença inconveniente de símbolos e signos pictóricos que dificultam a interpretação de dados e fatos (CASTROGIOVANNI, 1995, p.149). 
Para a proposta de atividade aplicada nesta pesquisa buscou-se apoio em suas orientações também, à medida que se ensina a gramática da representação gráfica, segundo a Semiologia gráfica, portanto, ensina-se a linguagem dos mapas. A seguir apresenta-se o quadro das variáveis visuais que foi utilizado nas aulas expositivas:

\section{Quadro 3: As variáveis visuais e as duas dimensões do plano}

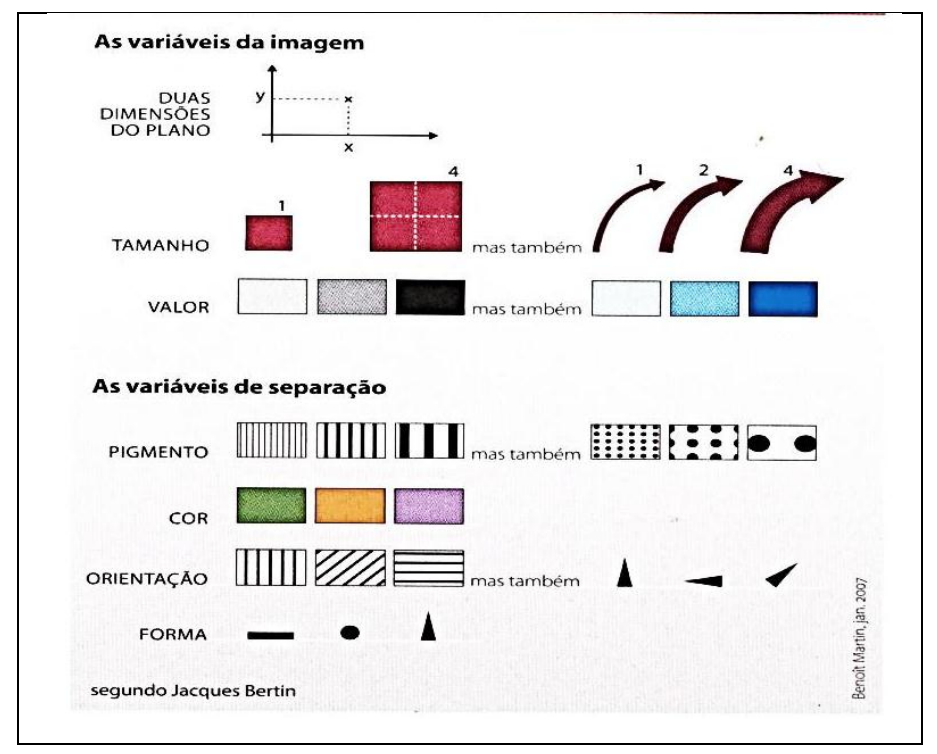

Adaptado de DURAND, Marie-Françoise et al. Atlas da Mundialização: compreender o espaço mundial contemporâneo. São Paulo: Saraiva, 2009. p. 14.

Este por si mesmo leva os alunos a entenderem que os símbolos pictóricos devem ser abolidos das representações. Os mapas não podem trazer ambiguidades nas informações. Entende-se, com relação àquilo que Antônio Carlos Castrogiovanni chama de sensibilidade geográfica, que se o objeto de estudo da Geografia for apresentado aos alunos de maneira que explicite a sua realidade vivida, eles poderão desenvolver a sensibilidade geográfica para observação, análise e correlação na construção e leitura das representações necessárias desse espaço.

Observar criteriosamente as informações do quadro permite considerar que a partir de uma localização no plano (e aqui entra a necessidade de os alunos saberem localizar os objetos, quer nos estados, países, cidades, enfim) será possível "combinar essas variáveis visuais aos três 'primitivos gráficos': o ponto, a 
linha e a superfície" (DURAND, 2009, p.14). Esse cuidado corresponderá à produção de mapas temáticos que não permitem ambiguidades.

Colabora também para a necessidade das atividades em sala de aula com mapas, Maria Elena Ramos Simielli, que traz os termos "aluno leitor e construtor de mapas" e aborda considerações sobre a prática de ensino de Geografia com essa forma de representação. A autora apresenta dois eixos de trabalho possíveis para o ensino de Geografia: no primeiro sugere que se trabalhe com o mapa pronto para obter um aluno leitor crítico ao final do processo. No segundo, objetiva ter um aluno mapeador consciente, pois o aluno participará da construção. Ainda propõe que se trabalhem três níveis: localização, análise, correlação e síntese a partir da $4^{\underline{a}}$, $5^{\underline{a}}$ série (Cf. Simielli, 2002, p. 98-99), o que hoje corresponderia ao $5^{\circ}$ e $6^{\circ}$ anos do ensino fundamental respectivamente. É preciso esclarecer que como o objetivo inicial das atividades era a verificação do universo cartográfico dos alunos, na sequência didática de número um (01) apenas se apresentou os mapas prontos a eles com um questionário em anexo para ser respondido com base na análise dos mapas. As discussões sobre a estrutura dos mapas ocorreu somente depois, na sequência das atividades.

Seguindo parcialmente a sugestão da autora, optou-se por trabalhar inicialmente com alunos a partir da $6^{\underline{a}}$ série $^{37}$, uma vez que esses alunos já deveriam ter tido contato com mapas na $5^{\text {a }}$ série. Também se trabalhou com três salas de $1^{\circ}$ ano ensino médio EJA, e posteriormente com duas salas de $7^{\circ}$ ano, ensino fundamental regular.

Por uma questão de praticidade com relação à aquisição do material necessário em sua totalidade, ou seja, a Xerox dos fundos de mapa para todo o público alvo da pesquisa optou-se por trabalhar com um único fundo de carta nas atividades práticas, um mapa do Brasil. Mas, entende-se que tanto a escolha da escala geográfica como da escala cartográfica poderia ter sido outra sem que houvesse prejuízo para as atividades propostas.

Para iniciar as atividades foi utilizada a sequência didática elaborada e apresentada a seguir.

Esta sequência didática deve servir apenas como um exemplo de atividade prática, pois o professor deve ter em mente que cada aluno possui um

\footnotetext{
${ }^{37}$ No ano 2009 , em que teve início a atividade prática da pesquisa ainda se dizia $6^{\underline{a}}$ série.
} 
desenvolvimento específico. Cada classe é diferente da outra, e é parte da atividade prática do professor adequar o material didático ao qual tem acesso, ao seu público. Esta verificação se deu ao aplicar as atividades em salas e níveis de ensino diferentes, e foi necessário adequar os conteúdos a cada um deles, embora tenham sido necessárias apenas adequações mínimas durante a aplicação prática desta pesquisa.

\section{SEQUÊNCIA DIDÁTICA UTILIZADA E SUGERIDA - 01}

Tema: A cartografia temática nas aulas de Geografia

Conteúdo: Linguagem cartográfica.

Objetivos: Compreender a Cartografia como linguagem visual que é representada graficamente, baseada na gramática da representação gráfica e a importância de sua interpretação para o ensino de Geografia, permitindo assim que os alunos tenham a possibilidade de adquirir conhecimentos geo-cartográficos.

Ano de aplicação: A partir do $7^{\circ}$ ano do ensino fundamental

Tempo estimado: 15 aulas

Material necessário: mapas diversos construídos sob a gramática da representação gráfica regida pela Semiologia Gráfica, portanto que funcionem enquanto linguagem visual; lápis, mapas base do território brasileiro, tabela com dados específicos a cada conteúdo, borracha, lápis de cor, caderno e régua.

\section{Desenvolvimento:}

1ㄹ etapa: Os alunos devem ser dispostos em pequenos grupos de trabalho. SerIhes-á proposto que respondam algumas questões, de um questionário investigativo, sobre mapas previamente selecionados que devem estar em anexo no referido questionário, para serem consultados (apresenta-se adiante no texto uma sugestão de questionário). É necessário que os mapas selecionados funcionem como linguagem visual, ou seja, obedeçam à gramática da representação gráfica, conforme a Semiologia gráfica, e que respondam questões apenas com o olhar. Caso o professor não disponha desse material, não há problema em se trabalhar com o que se tem, independente dos critérios utilizados para a construção dos mapas que existam na escola no momento da aplicação da atividade, desde que sejam feitas as considerações necessárias oportunamente. O importante é trabalhar com mapas. Incluam-se também alguns mapas com os quais os alunos já estejam 
familiarizados. Nesta etapa não se deve dar informação alguma aos alunos além da orientação para observar os mapas e responder ao questionário. Deve-se sempre ter em mente que o objetivo desta parte das atividades é verificar o universo cartográfico dos alunos.

2ª etapa: Após o procedimento de análise das respostas obtidas iniciam-se as aulas expositivas sobre cartografia temática, uma breve história da cartografia inclusive, e a apresentação, para o ensino, do quadro das variáveis visuais, e a discussão sobre alguns dos mapas que estavam no questionário inicial. Por ser uma linguagem gráfica visual espera-se que um mapa possa ser visto, lido e interpretado por qualquer pessoa, tanto no Brasil como na França, por exemplo. Essa informação deve ser passada para os alunos, pois um mapa deve ser elaborado dentro de uma estrutura monossêmica ${ }^{38}$, e o seu construtor deve tê-la em mente no momento da construção cartográfica. Este, inclusive, parece ser o momento de apresentar aos alunos alguns dos elementos do mapa: título, legenda, escala cartográfica, toponímia, simbólico ${ }^{39}$ (signos) e as referências gráficas. Deve-se destacar a importância de se colocar o título, as fontes a legenda, que é a chave da interpretação do mapa. A observação inclui também que os fenômenos podem ser representados nos mapas em pontos, linhas e áreas sobre um mapa base, pois assim eles se manifestam na realidade. No caso específico deste trabalho, o mapa base escolhido foi o mapa da divisão regional oficial do Brasil, segundo o Instituto Brasileiro de Geografia e Estatística (IBGE). Cabe ao professor adequar o quanto e até onde chegar com as informações dependendo do nível dos seus alunos. Um quadro mais geral e simplificado das variáveis visuais seria satisfatório no ensino fundamental regular a partir do $7^{\circ}$ ano. Com relação ao público da Educação de Jovens e adultos, somente o professor poderá, conhecendo seus alunos, saber qual o nível deles e qual a quantidade de informações mais adequada.

3a etapa: De posse das orientações iniciais os alunos já poderiam retomar as atividades com os mapas apresentados no questionário. É o momento do aluno construtor de mapas. O professor deve procurar dar destaque às informações dos

\footnotetext{
${ }^{38}$ Segundo Marcello Martinelli (MARTINELLI, 2008, p.13): de significado único, não permite ambiguidades.

39 Optou-se por designar simbólico apenas os signos da linguagem visual, uma vez que os símbolos também formam uma linguagem que pode ser a verbal.
} 
mapas inicialmente apresentados ressaltando como elas estavam sendo transmitidas visualmente.

4ª etapa: Dá-se então início aos exercícios de construção cartográfica. Inicialmente apresenta-se um pequeno texto informando que o Brasil está dividido em cinco regiões administrativas segundo o Instituto Brasileiro de Geografia e Estatísticas (IBGE), como uma das possibilidades de regionalização do território brasileiro e, que os mapas que serão elaborados devem transmitir informações de todas essas regiões. Deve-se agora apresentar-lhes tabelas com os dados que se desejar representar, e que podem, propositalmente, apresentar os dados fora de uma ordem crescente, inclusive. Este fato possibilitaria que os alunos trabalhassem com a ordenação numérica. À sequência eles devem ser informados que devem construir um mapa, com base na tabela, que represente o referido fenômeno. É aqui também que é necessário informar-lhes que eles devem colocar os referidos dados da tabela em ordem crescente e depois escolher o signo que melhor os represente no mapa. Ao final de cada aula procura-se levar os alunos a compreender como o mapa elaborado por eles poderia explicar, por intermédio dos fenômenos representados, questões sociais e a sua espacialização. O mapa poderia revelar o conteúdo da informação selada nos dados que foram trabalhados. E, neste momento também propiciar aos alunos a aquisição de conhecimentos geográficos, por intermédio da leitura e interpretação dos mapas que eles mesmos construíram. O papel do professor como mediador e norteador da atividade é fundamental.

5ª etapa: Para a fixação dos conhecimentos cartográficos adquiridos durante todas as atividades entende-se que seria necessário aplicar um exercício onde os alunos deveriam localizar alguns mapas num material didático acessível. Com um livro didático presente na escola, por exemplo, e com o qual os alunos não tenham trabalhado ainda, faz-se necessário que eles procurem mapas com representações de relações de diversidade, ordem e proporcionalidade.

6a etapa: Avaliação. Considera-se concomitantemente a participação de cada estudante nas tarefas em grupo, o resultado da elaboração cartográfica e do exercício de fixação, a partir do resultado do questionário inicial. 


\section{SEQUÊNCIA DIDÁTICA UTILIZADA E SUGERIDA - 02}

Tema: A cartografia temática nas aulas de Geografia

Conteúdo: Linguagem cartográfica.

Objetivos: Compreender a Cartografia como linguagem visual que é representada graficamente, baseada na gramática da representação gráfica e a importância de sua interpretação para o ensino de Geografia permitindo assim que os alunos tenham a possibilidade de adquirir conhecimentos geo-cartográficos.

Ano de aplicação: A partir do $7^{\circ}$ ano do ensino fundamental

Tempo estimado: 03 aulas

Material necessário: Lápis, mapas base do território brasileiro, borracha, caderno e régua.

\section{Desenvolvimento:}

1' etapa: Os alunos devem ser dispostos em pequenos grupos de trabalho. SerIhes-á proposto um desafio.

2 ${ }^{\text {a }}$ etapa: Neste momento deve ser colocada na lousa uma tabela que informe os dados, por estado ou por região, que os alunos deverão representar visualmente. Esta tabela deve ser copiada pelos alunos em seu caderno. Neste caso existem duas possibilidades: A tabela pode ser apresentada propositalmente fora de ordem crescente, para que eles a coloquem em ordem numérica do menor para o maior para depois pensar a ordem visual. Ou ainda: como já há um desafio proposto, apresenta-se a tabela já em ordem crescente e os alunos teriam apenas que descobrir a ordem visual para os dados numéricos. Nessa parte da atividade se 0 professor perceber que há necessidade, é possível também colocar o quadro das variáveis visuais na lousa, e os alunos poderiam escolher entre as variáveis mais adequadas para representar o fenômeno em questão.

3 ${ }^{\mathbf{a}}$ etapa: O professor caminha entre os grupos para instigá-los a descobrir a ordem visual. É importante que os alunos saibam que não há o "errado" neste momento. Todas as possibilidades devem ser apresentadas para poder ser discutidas depois.

4a etapa: Com os mapas prontos, todos eles devem ser apresentados, de uma só vez para a turma que, com o auxílio do professor será direcionada a "ver" cada um dos mapas elaborados. A pergunta chave é: Em qual dos mapas é possível ver imediatamente uma ordem visual? Os próprios alunos, embora não desejem que seus trabalhos não sejam aceitos, acabam por concordar que não é possível ver 
uma ordem visual se não for por meio da variável visual valor. Ou ainda da variação do tamanho, dependendo da informação numérica que o professor forneceu inicialmente (se trabalhou com classes ou valores absolutos).

5a etapa: O professor deve apresentar as duas variáveis visuais, tamanho e valor, aos alunos. Elas foram descobertas pela turma e utilizadas em mapas como recurso visual para evidenciar as suas descobertas. O professor, neste momento, deve informar-lhes sobre a gramática da representação gráfica de dados na construção de mapas. Sempre tendo em mente que é este o momento que os conhecimentos geográficos devem ser evidenciados e não apenas os conhecimentos cartográficos. 6⿳亠口冋口 etapa: Avaliação. Valoriza-se a participação de cada estudante nas tarefas em grupo.

Com relação à aplicação das sequências didáticas apresentadas, considerase que seria ao término da última das etapas que o professor poderia refletir sobre a aplicação da atividade, pois já teria acompanhando todas as fases de sua aplicação, e já teria tido oportunidade de analisar cada momento e os seus resultados práticos. Rever o método e os procedimentos, analisando os resultados obtidos pelos alunos. Mas, e principalmente, os seus próprios atos, a organização das aulas, a forma de apresentação dos conteúdos, a maneira que sugeriu que seus alunos trabalhassem, individualmente ou em grupos, como e se conseguiu apresentar uma Geografia explicativa, social. Enfim, seria nesta fase do trabalho que o professor teria a oportunidade de refletir sobre sua prática de ensino. O que pressupõe uma reflexão diária, pois cada etapa permite ao professor pensar sobre os resultados parciais, que possibilitarão a análise do todo.

Entende-se, inclusive que esta sequência didática deve ser aprofundada em aulas posteriores no sentido de que não seja apenas a escolha da variável visual o importante. Os conhecimentos cartográficos ajudam no processo de aprendizagem e são parte dele. Assim, os alunos conhecendo a sua aplicação podem ler e interpretar mapas que utilizem a variáveis visuais e sob a orientação do professor podem adquirir conhecimentos geográficos inclusive.

A tabela número 01 foi utilizada na última sequência didática e deu origem aos mapas construídos na atividade de desafio. 
Tabela n 01: Brasil - Urbanização

\begin{tabular}{lc}
\hline \multicolumn{1}{c}{ Nome dos Estados } & Porcentagem \\
\hline $\begin{array}{l}\text { Acre, Rondônia, Roraima, Maranhão, } \\
\text { Piaui, Bahia, Alagoas. }\end{array}$ & 62 a 70 \\
$\begin{array}{l}\text { Amazonas, Amapá, Pará, Tocantins, } \\
\text { Mato Grosso, Ceará, Rio Grande do } \\
\text { Norte, Paraíba, Pernambuco e Rio } \\
\text { Grande do Sul. }\end{array}$ & 71 a 80 \\
$\begin{array}{l}\text { Sergipe, Goiás, Mato Grosso do Sul, } \\
\text { Minas Gerais, Espírito Santo, Paraná } \\
\text { e Santa Catarina. }\end{array}$ & 81 a 90 \\
São Paulo e Rio de Janeiro & 91 ou mais \\
\hline
\end{tabular}

Fonte: IBGE, 2004.

Alguns dos mapas resultantes serão apresentados oportunamente, assim como comentários críticos sobre os resultados das construções.

É conveniente informar que frente à possibilidade de estar em exercício numa escola da rede pública estadual de São Paulo, optou-se por retirar alguns dos mapas utilizados na atividade diagnóstica dos materiais fornecidos pela Secretaria Estadual de São Paulo, como mencionado anteriormente. Considerando-se que os alunos teriam acesso a eles durante todos os anos da educação básica, por que não fazer com que esses alunos aprendessem a gramática da representação gráfica utilizando-os?

No entanto, a seguir serão feitas algumas considerações críticas aos mapas selecionados para a atividade inicial, diagnóstica.

\subsubsection{Alguns dos mapas iniciais: considerações críticas}

A seleção de mapas apresentados a seguir foi pensada para evidenciar uma análise feita anteriormente à aplicação da atividade diagnóstica, que serviu inclusive, para novas discussões com os alunos após as aulas expositivas sobre a gramática da representação gráfica.

Cada um dos mapas da sequência foi apresentado aos alunos, inicialmente apenas para verificar o universo cartográfico deles. Em seguida, durante as aulas expositivas sobre essa gramática, a cada variável visual apresentada e discutida, retomava-se o mapa com a mesma variável visual apresentado na atividade 
diagnóstica e tecia-se uma discussão com os alunos sobre as possibilidades de reconstrução dos mesmos, adequadamente à gramática dos mapas. O objetivo era que eles se tornassem leitores críticos de mapas.

A maior dificuldade encontrada nessas discussões foi que os alunos relutavam a entender, e aceitar, que um material que lhes é apresentado para uso contínuo pela própria escola, como um atlas geográfico escolar, ou mesmo um mapa enviado pelo próprio IBGE pudesse apresentar erros. Principalmente os adultos da Educação de Jovens e Adultos (EJA ) tiveram grande dificuldade em aceitar que eles mesmos, após aprenderem a gramática da representação gráfica, poderiam reconstruir os mapas que apresentavam erros cartográficos.

Optou-se por apresentar esses mapas na sequência deste próprio texto, e não como anexos. O fato é que se entende que tanto as críticas como os mapas apresentados são parte importante do trabalho, pois, ambos permitiram a aplicação prática da gramática da representação gráfica junto aos alunos.

Nos mapas 01 e 02 são apresentadas discussões sobre ruídos visuais; no mapa 03 discorre-se sobre a aplicabilidade e eficácia das anamorfoses para o ensino e a aprendizagem e no mapa 04 destacam-se as orientações de Marcello Martinelli com relação à necessidade da coleção de cartas. Evidencia-se que, para a cartografia escolar, utilizada como linguagem, é preciso que se trabalhe com mapas mais cognitivos e a coleção de cartas, construída sob a orientação da gramática da representação gráfica seria ideal.

É necessário retomar o que afirmam Fernanda Padovesi Fonseca e Jaime Tadeu Oliva:

Ora, se a semiologia gráfica nos oferece uma linguagem que se caracteriza por ser atemporal e espacial, estamos diante de uma forma que poderia ser ao mesmo tempo instrumento de análise e de expressão dos conhecimentos geográficos, fazendo da cartografia um campo de desenvolvimento do pensamento geográfico. (FONSECA e OLIVA, 2002, p.69).

Uma cartografia que se apoie na gramática da representação gráfica, pode se tornar um instrumento de análise e reflexão, tanto no ensino quanto para a aprendizagem.

Assim, a busca pela aplicação prática de uma cartografia que seja coerente com o espaço geográfico contemporâneo, que seja facilitadora da aquisição de conhecimentos geo-cartográficos, portanto, instrumento de análise e de expressão 
desses conhecimentos, é também o motor deste trabalho, ainda que, em parte, apenas teoricamente.

Neste sentido, procura-se comentar alguns dos mapas utilizados na atividade inicial, diagnóstica.

Mapa 01: As migrações, final do século XX.

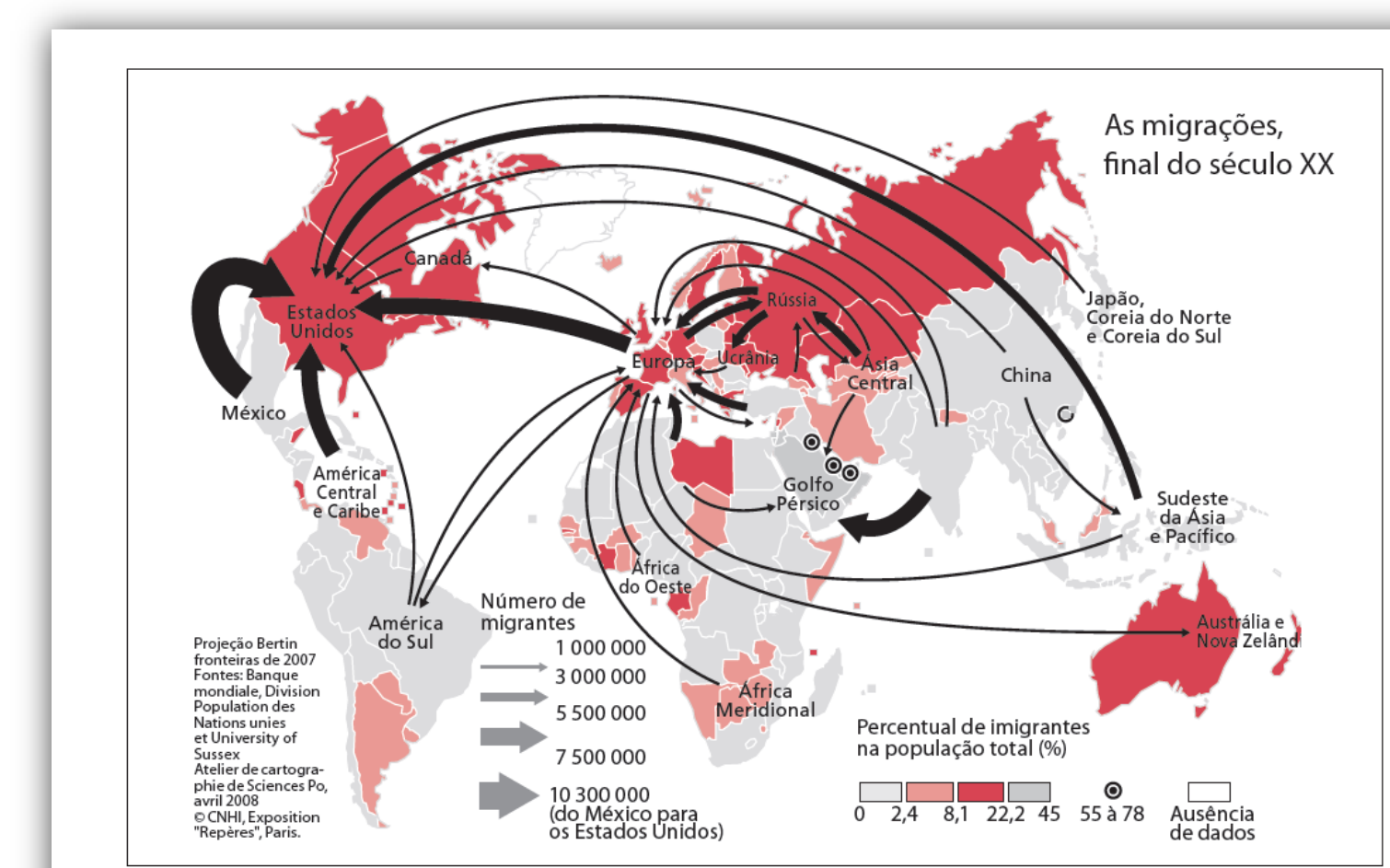

Figura 2 - As migrações, final do século XX. Fonte: Atelier de Cartographie de Sciences Po. Disponível em: <http://cartographie dessciences-po.fr/cartotheque/03web_migrants_BAT.jpg>. Acesso: 7 out. 2008.

Figura 2: Mapa 01: As migrações, final do século XX. Apud SÃO PAULO (Estado) Secretaria da Educação. In FINI, Maria Inês. Coord. São Paulo: SEE, 2009. Caderno do professor - Geografia - ensino médio, 1응 ano, São Paulo: SEE, 2009, v. 2, p. 15.

Este mapa da figura 02 é uma representação ordenada e dinâmica (MARTINELLI, 2008, p.34). Mostra o fluxo de imigrantes, num determinado período, pelas regiões do mundo e as suas quantidades. Informa também o percentual de imigrantes na população total. O mapa responde visualmente às questões: Em que ordem? Onde? E para onde? Por exemplo. No entanto há um certo ruído visual provocado pela toponímia (nomes de alguns países e regiões).

No mapa da figura 03, que é uma representação ordenada, foi utilizada corretamente a variável visual valor, uma variável de imagem. A resposta visual é instantânea. No entanto ao se aprofundar nos dados, verifica-se que as legendas deveriam sofrer algumas alterações: o quadro da legenda deve sempre iniciar do 
menor dado para o maior (MARTINELLI, 2008, p. 46), e não como aparece no mapa. Outra observação: deveria ser colocado o sinal de porcentagem no quadro da legenda onde se lê: "MÁXIMO" e "MÍNIMO", e posicionar essa outra informação ao lado da legenda geral. Não seria mais "limpa” uma representação com apenas duas informações numa mesma legenda? Haveria a eliminação do ruído visual. A gradação do valor permite a visualização de onde há mais e de onde há menos, e uma toponímia abreviada ajudaria na localização. Outra questão é referente às outras informações junto da imagem, como a fonte, por exemplo, isto caracteriza ruídos visuais no mapa (Cf. Board,1975. P.139-184).

Mapa 02: Esperança de vida - 2000- 2005.

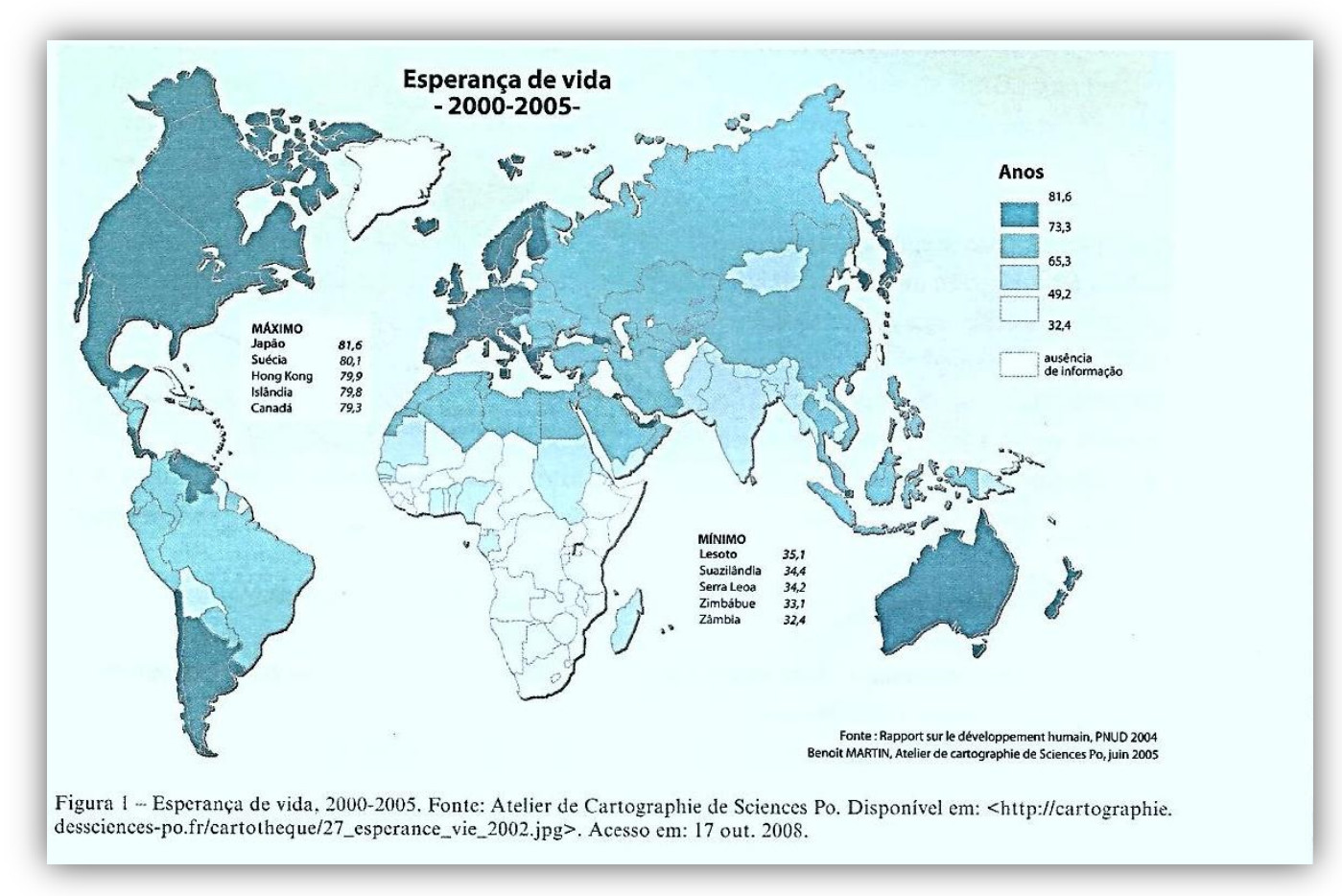

Figura 03: Mapa 02: Esperança de vida, 2000-2005. Apud SÃO PAULO (Estado) Secretaria da Educação. In FINI, Maria Inês. Coord. São Paulo: SEE, 2009. Caderno do professor: geografia, ensino fundamental 8ª́ série, São Paulo: SEE, 2009, v. 3, p. 33.

O mapa da figura 04 utiliza a variável visual cor. Segundo a gramática da representação gráfica, se o fenômeno representado for apenas um, ou seja, se o mapa trouxer informações sobre o mesmo fenômeno, a cor não deve ser utilizada. A cor é uma variável de separação (MARTINELLI, 2008, p.16). Essa variável visual foi utilizada nestes mapas para separar visualmente os diversos países e facilitar a 
interpretação dos dados populacionais demonstrados pela variação do tamanho do fundo do mapa, sob a métrica populacional, inclusive.

Mapa 3: Anamorfose e mapa territorial de referência

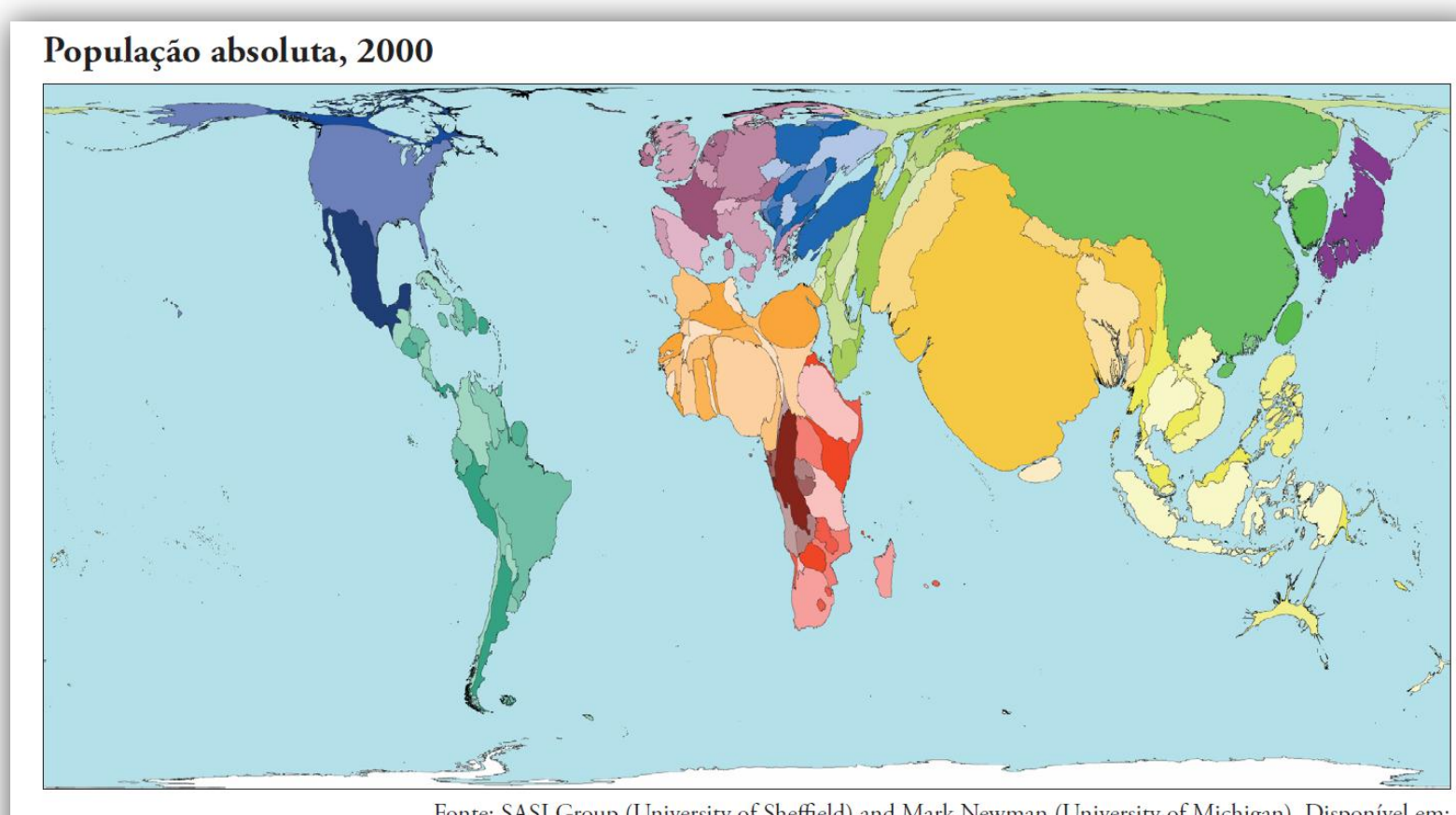

Fonte: SASI Group (University of Sheffield) and Mark Newman (University of Michigan). Disponível em: <http://www.worldmapper.org/display.php?selected=2>. Acesso em: 15 out. 2009.

Mapa territorial de referência

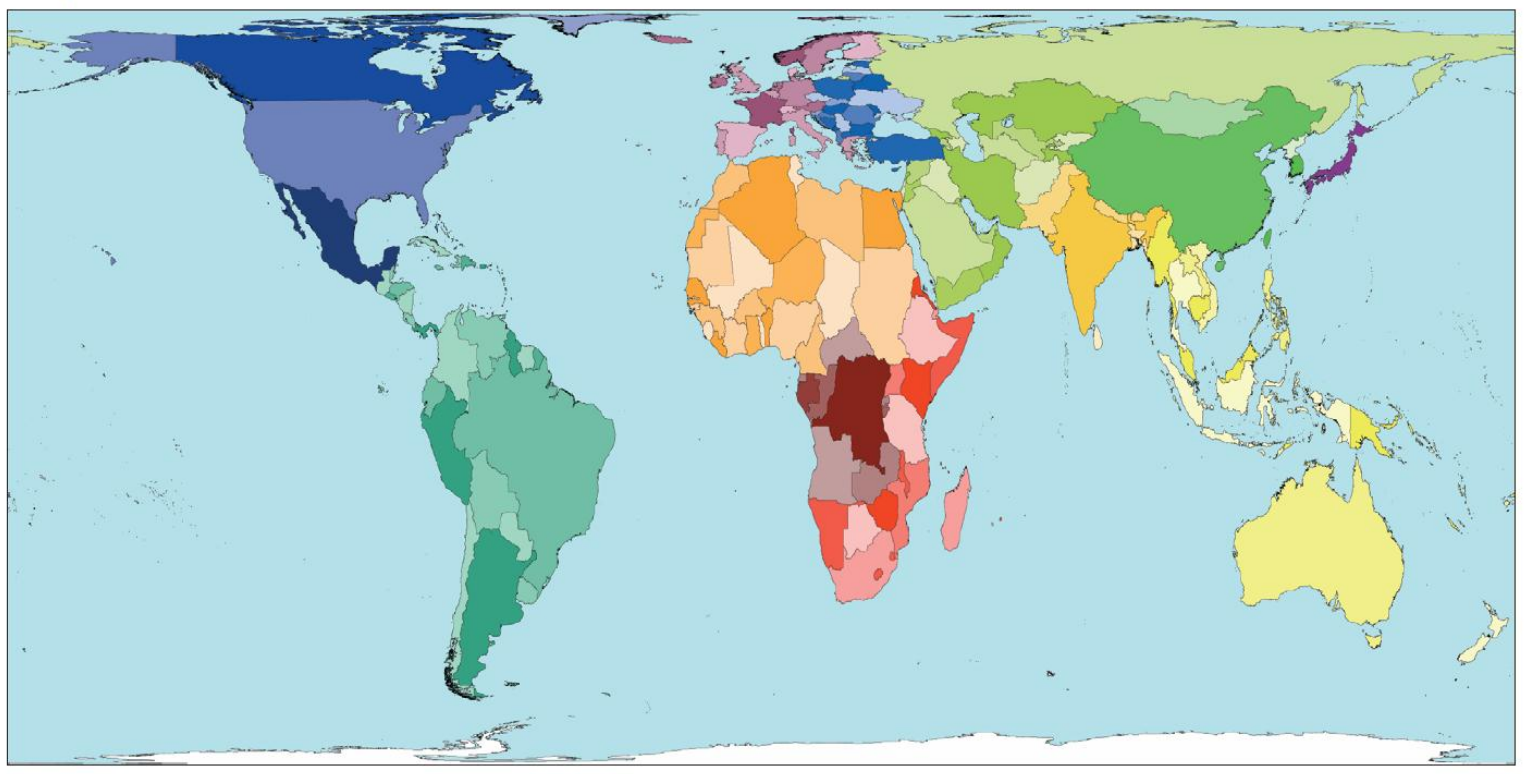

Fonte: SASI Group (University of Sheffield) and Mark Newman (University of Michigan). Disponível em: <http://www.worldmapper.org/display.php?selected=2>. Acesso em: 15 out. 2009.

Figura 4: Exemplo de Anamorfose e mapa territorial de referência. Apud SÃO PAULO (Estado) Secretaria da Educação. In FINI, Maria Inês. Coord. São Paulo: SEE, 2009. Caderno do aluno - ensino médio - 1ํㅡㄴ ano, São Paulo: SEE, 2009, v. 1, p. 16. 
Ao utilizar a cor, a resposta visual do fenômeno populacional não foi prejudicada. Portanto, entende-se que o mapa responde visualmente onde há mais e onde há menos população, conforme a variação do tamanho do fundo do mapa. Entende-se que seja preciso transmitir essas considerações para os alunos, já que se pretende formar alunos críticos e mapeadores conscientes (SIMIELLI, 2002, p. 99). Estes mapas são uma anamorfose e um mapa territorial de referência. Ao utilizá-los tem-se como objetivo verificar se os alunos já trabalharam com uma anamorfose antes. Entende-se que se a intenção é mostrar o quanto de população há em determinado lugar, a troca do fundo territorial pelo fundo com a métrica populacional parece mais conveniente. Ao olhar as duas representações é possível "ver" que o Japão "cresceu" na representação anamórfica, se comparado com o fundo territorial. "Esses mapas são muito atrativos, uma vez que apresentam o duplo interesse de mostrar uma geografia adequada ao fenômeno representado e de se liberar das distâncias físicas" (DURAND, 2009, p.16). A variação do tamanho permite visualizar instantaneamente onde tem mais e onde tem menos. Assim, não seria mais cognitivo utilizar o fundo com métrica populacional ao invés do tradicional fundo territorial na Geografia escolar? No entanto, sugerir-se-ia que até que os alunos se acostumem com a anamorfose, seja sempre utilizado um mapa de fundo territorial de referência junto. Neste caso, os alunos poderiam utilizar o fundo territorial para localizar os países (ou conforme a escala escolhida) e comparar com as alterações apresentadas pela anamorfose.

Observe-se agora o mapa da figura 05 que é uma representação qualitativa. Nele há a utilização correta da variável visual forma, uma variável de separação. No entanto é um mapa exaustivo. Para ser utilizado a contento pela cartografia escolar, o ideal seria que ele fosse apresentado junto com uma coleção de cartas como sugere o seu autor Marcello Martinelli (MARTINELLI, 2008,p.37-38). Nesse caso a informação visual seria satisfatória, e o público alvo teria acesso imediato às informações necessárias, sem que tivesse que consultar a legenda inúmeras vezes, pois haveria uma resposta visual imediata das informações.

Todas as observações feitas acima foram de alguma maneira tratadas com os alunos público alvo desta pesquisa. Entende-se que para a formação de conhecimentos, é preciso que sejam fornecidas todas as informações que se julguem relevantes no processo de ensino e aprendizagem. 
Mapa 04: Recursos Minerais do Brasil

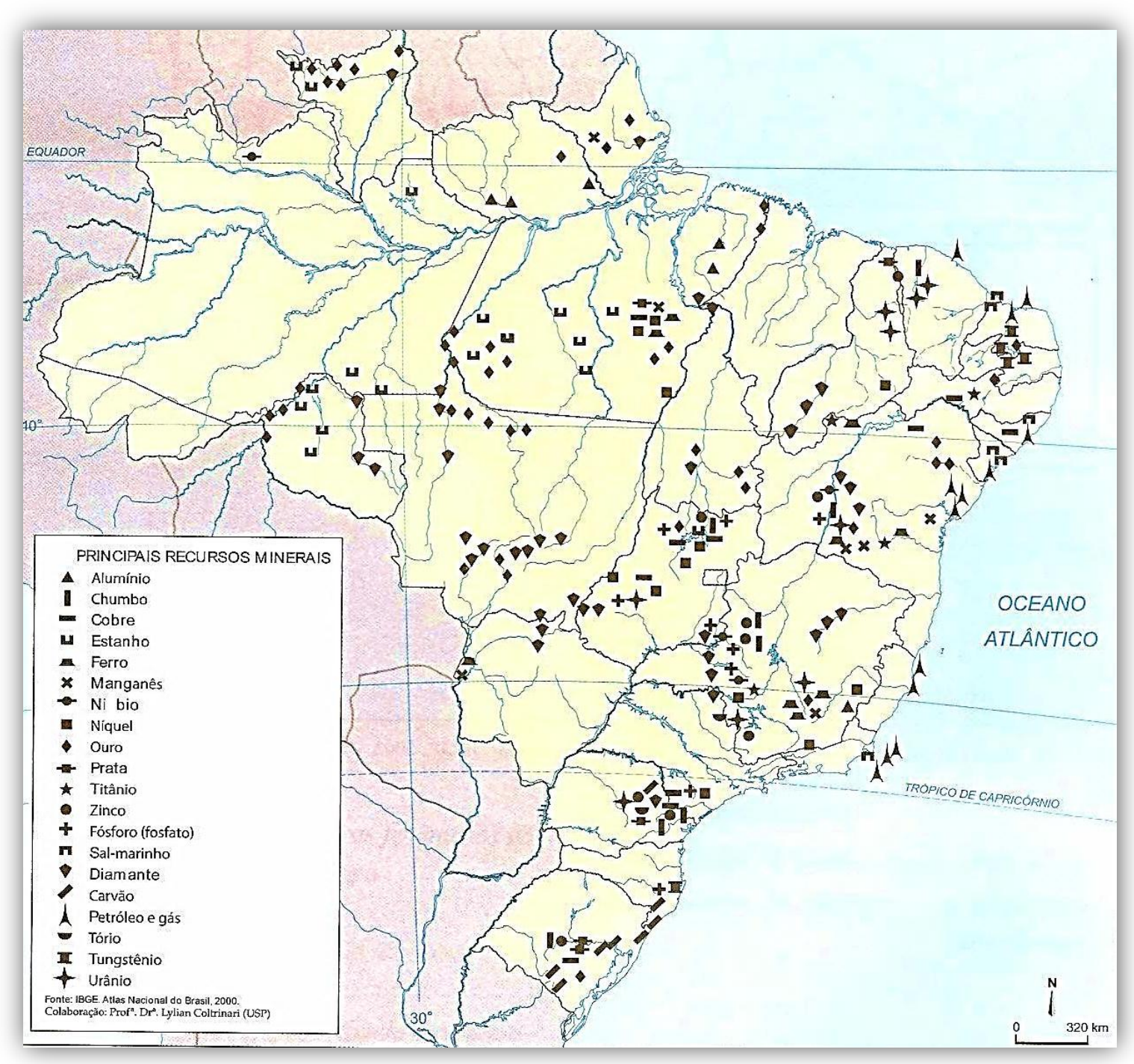

Figura 5: Mapa Recursos minerais do Brasil. Fonte: IBGE. Atlas Nacional do Brasil, 2000. Apud São Paulo (Estado) Secretaria da Educação. In FINI. Maria Inês. Coord. Caderno do professor: geografia, ensino fundamental - 5a série, v. 2, p.35. São Paulo: SEE, 2009.

Ressalta-se que, para a realização da atividade diagnóstica, haveria também a possibilidade de o próprio professor elaborar mapas conforme a gramática da representação gráfica e os levar para a sala de aula.

Todavia, não se considera um problema trabalhar com os mapas como eles estão, aliás, o que mais há nos materiais didáticos disponíveis nas escolas são 
materiais que nem ao menos apresentam corretamente a gramática da representação gráfica.

Outra questão é que eles não foram elaborados especificamente para a Geografia escolar. Sendo assim, o que se poderia classificar como um problema pode ser revertido para uma oportunidade de aprendizagem e ampliação do universo cartográfico dos alunos. O fato é que quando eles se depararem com mapas que não respondam às questões que lhes forem postas, os mesmos alunos terão subsídios para uma análise crítica do material.

Não se quer afirmar aqui que se espera que um aluno de $7^{\circ}$ ano já seja capaz dessa análise, no entanto, se os alunos se familiarizarem a trabalhar como instrui a gramática da representação gráfica desde as séries iniciais do segundo ciclo do ensino fundamental, com o tempo, eles o serão.

\subsubsection{Atividades práticas com alunos}

Inicialmente pretendia-se verificar o quanto e até onde o aluno conseguiria trabalhar sozinho com os mapas e, inclusive, verificar o seu universo cartográfico. É preciso ressaltar que a minha participação neste momento limitou-se à entrega do material e à solicitação feita no sentido de que os alunos deveriam observar os mapas que receberam e então responder o questionário. Esse questionário poderia se tornar uma porta de entrada para as reflexões do professor, com a finalidade de ele mesmo preparar seus questionários adequados aos alunos, que só ele conhece. Neste sentido entende-se que "é real a existência de múltiplas restrições, condicionamentos e forças socializantes, mas é também evidente que há margens para a expressão da individualidade profissional" (SACRISTÁN, 1991, p.73).

Ao aplicar os exercícios foram dadas explicações sobre a regionalização do espaço brasileiro, no entanto não foi feita nenhuma discussão mais detalhada sobre escala cartográfica, ela foi apenas apresentada, pois não era esse o objetivo do exercício nesta etapa de construção de conhecimentos. O importante era que os alunos conhecessem, nesse primeiro momento, a estrutura visual dos mapas.

Evidencia-se que após a aplicação na 6ª série também foi possível trabalhar com outras séries e nível de ensino, apenas adequando a metodologia de aplicação para o ensino da gramática da representação gráfica, iniciando-se sempre com uma breve história da utilização dos mapas e o quadro das variáveis visuais na sequência. 
Apresenta-se a seguir o questionário aplicado durante a atividade diagnóstica, que é a figura 06 . Na sequência a tabela 02 possibilita realizar uma análise da produtividade da aplicação da gramática da representação gráfica para a construção de mapas temáticos em aulas de Geografia.

\section{QUESTIONÁRIO}

1. O que é Cartografia e para que ela serve?

2. Quais são os elementos que transmitem informação num mapa?

3. Observe o mapa A-c e informe qual é o conjunto dos países onde as pessoas tinham mais de 60 anos em 2005.

4. Para as questões a seguir observe sempre os mapas aos quais elas se referem.

a) Porque foram utilizadas cores no planisfério como recurso visual?

b) O que significam as cores e os signos nos mapas da página $A$ b?

c) Entre o material que você recebeu existe uma anamorfose. Você é capaz de identificá-la? Então diga o que ela está comunicando e qual é o título dessa representação.

d) Qual é o tipo de representação utilizada no mapa "Recursos minerais do Brasil"?

e) Existe alguma relação entre as áreas representadas nos mapas e os signos nos mapas?

f) O que informam as setas de tamanhos diferentes existentes nos mapas? 
É preciso esclarecer que empiricamente verificou-se a necessidade de iniciar as atividades com um exercício de copiagem. Somente após esse exercício é que os alunos passaram a ter segurança para trabalhar com as regiões, mesmo tendo-Ihes sido apresentado um mapa base onde já haviam sido destacados os limites territoriais das mesmas. O fato que se constatou, via observação empírica, é que os alunos não trabalhavam com mapas normalmente nas aulas de Geografia, portanto o resultado é a não familiaridade com as divisões regionais, ainda que apenas a opção pela regionalização segundo o IBGE.

Na figura 07 é apresentado um mural de mapas produzidos com a utilização da cor azul no fundo com métrica territorial. Em cartografia a cor azul é normalmente associada a águas, no entanto, entende-se que nesta atividade o ideal seria que os alunos trabalhassem com a variável visual cor livremente, uma vez que ela seria utilizada apenas como variável de separação nas regiões nos mapas temáticos.

A figura 08 mostra um dos mapas do mural em detalhe. Nele, assim como nos outros mapas resultantes da atividade de copiagem a cor azul foi utilizada a contento para separar.

\subsection{Os mapas construídos pelos alunos}

Tabela 02: Tipo e quantidade dos mapas produzidos.

\begin{tabular}{rrrcc}
\hline Tipo & Corretos & Com erros & Inacabados & Total \\
\hline $\begin{array}{r}\text { Quantitativ } \\
\text { os }\end{array}$ & - & - & - & - \\
Estáticos & 14 & 09 & 05 & 28 \\
Dinâmicos & 05 & - & - & 05 \\
Ordenados & 41 & 06 & 02 & 49 \\
Qualitativo & & & & \\
s & 31 & 07 & 04 & 42 \\
Geral & 91 & 22 & 11 & 124 \\
\hline
\end{tabular}

Fonte: Dados levantados pela autora no período de 03/2008 a 12/2010 referentes à aplicação prática da pesquisa. 
As figuras apresentadas a seguir trazem alguns dos mapas construídos durante as atividades realizadas e alguns comentários sobre cada um deles.

Mapas iniciais

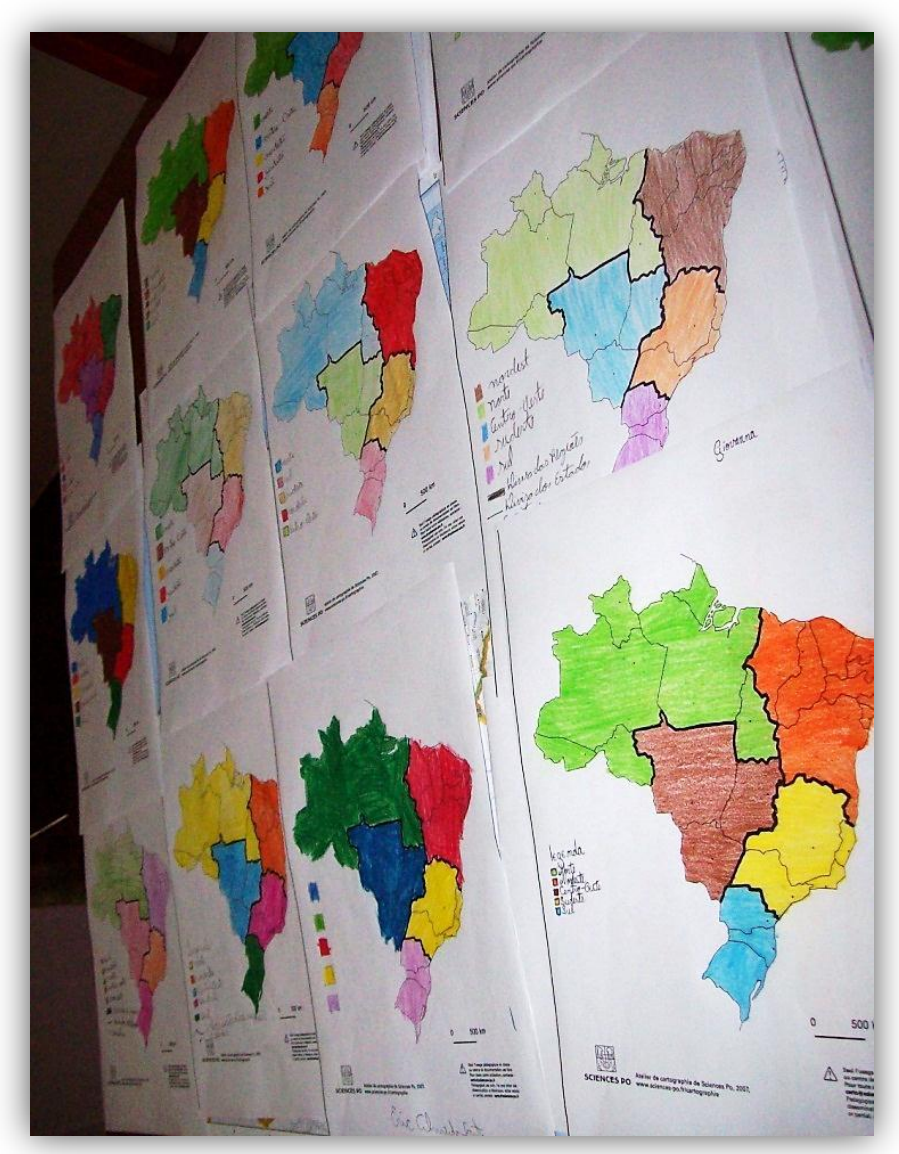

Figura 7: Mural de mapas. Foto tirada pela autora em 03/2009.

Para a aplicação da atividade de construção do mapa de população absoluta que é apresentado na figura 09 seria necessário preparar os círculos proporcionais seguindo as orientações de Marcello Martinelli com relação às figuras geométricas proporcionais (MARTINELLI, 2008, p. 51-52-53). No entanto, devido à faixa etária do público alvo inicial da pesquisa esses alunos ainda não poderiam fazer os cálculos necessários sozinhos, uma vez que ainda não teriam adquirido conhecimentos matemáticos para tal. Então se decidiu levá-los prontos. O objetivo era que os alunos pudessem primeiro escolher a variável visual adequada, apenas observando o quadro das variáveis visuais. Só então, Ihes seria entregue o conjunto de círculos proporcionais para colarem nos espaços do mapa. Assim que o primeiro 
grupo de alunos fez a escolha pela variável visual tamanho, foi-lhes entregue o conjunto de círculos proporcionais.

Todavia, este fato pareceu influenciar os grupos que ainda não haviam se decidido pela variável visual adequada. Então, nas demais séries e classes optou-se por não fazer os cálculos, apenas variar os tamanhos. Por este motivo houve um grande número de mapas que não consideraram as exatas proporcionalidades.

Brasil: Grandes Regiões - IBGE.
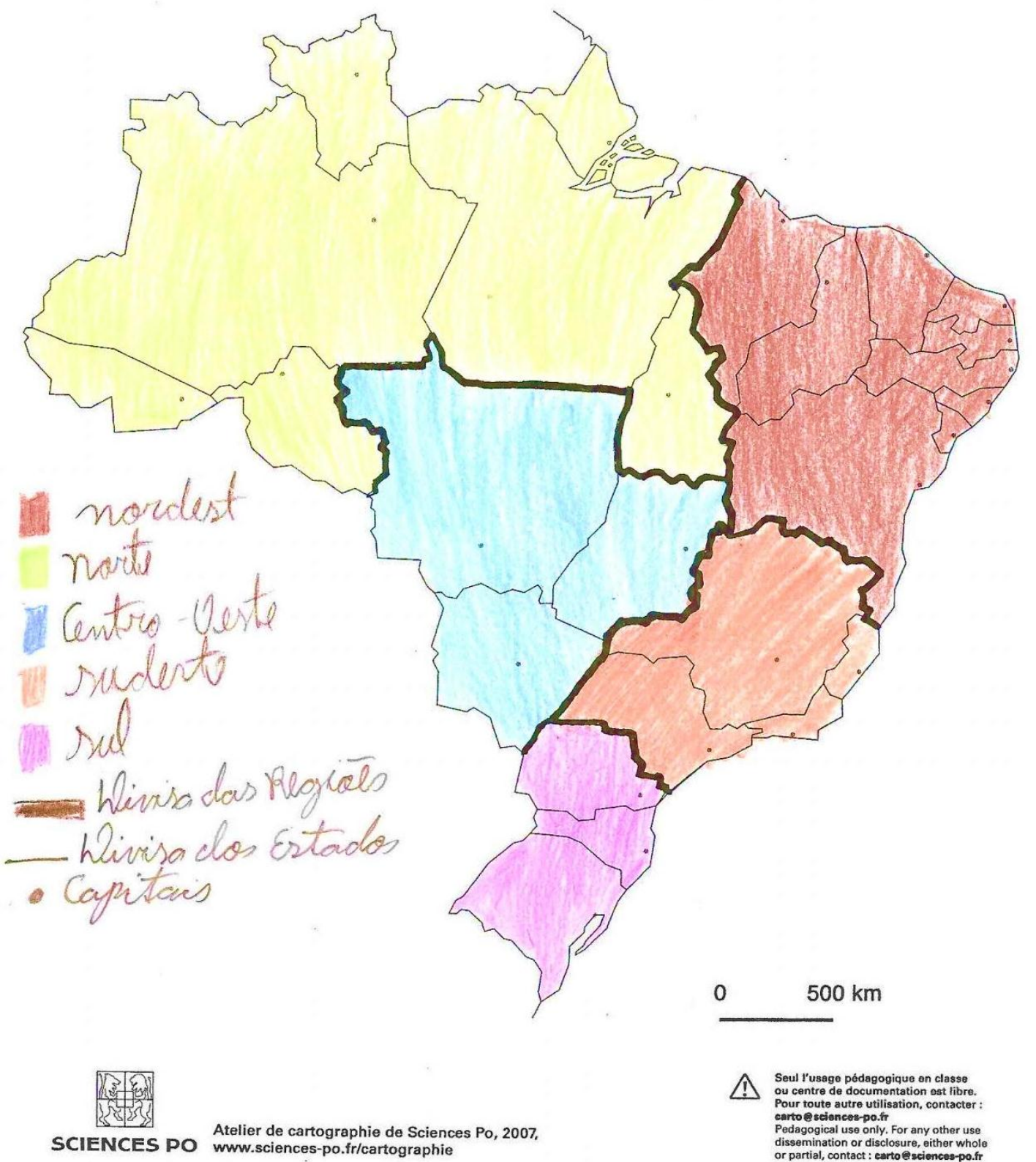

Figura 8: Mapa resultante de atividade de copiagem. 
E observa-se, como pode ser verificado na figura 10, que o resultado visual imediato é satisfatório. Caso seja necessário a legenda poderá colaborar para o acesso aos valores absolutos. Nessa mesma figura 10 que é um mapa produzido por alunos do ensino fundamental regular tem-se uma representação quantitativa com aplicação correta da variável visual tamanho. Vê-se que o que importou para a visualização foi a variação do tamanho e não a proporcionalidade entre eles. O que não prejudica a comunicação visual.

Brasil População Absoluta
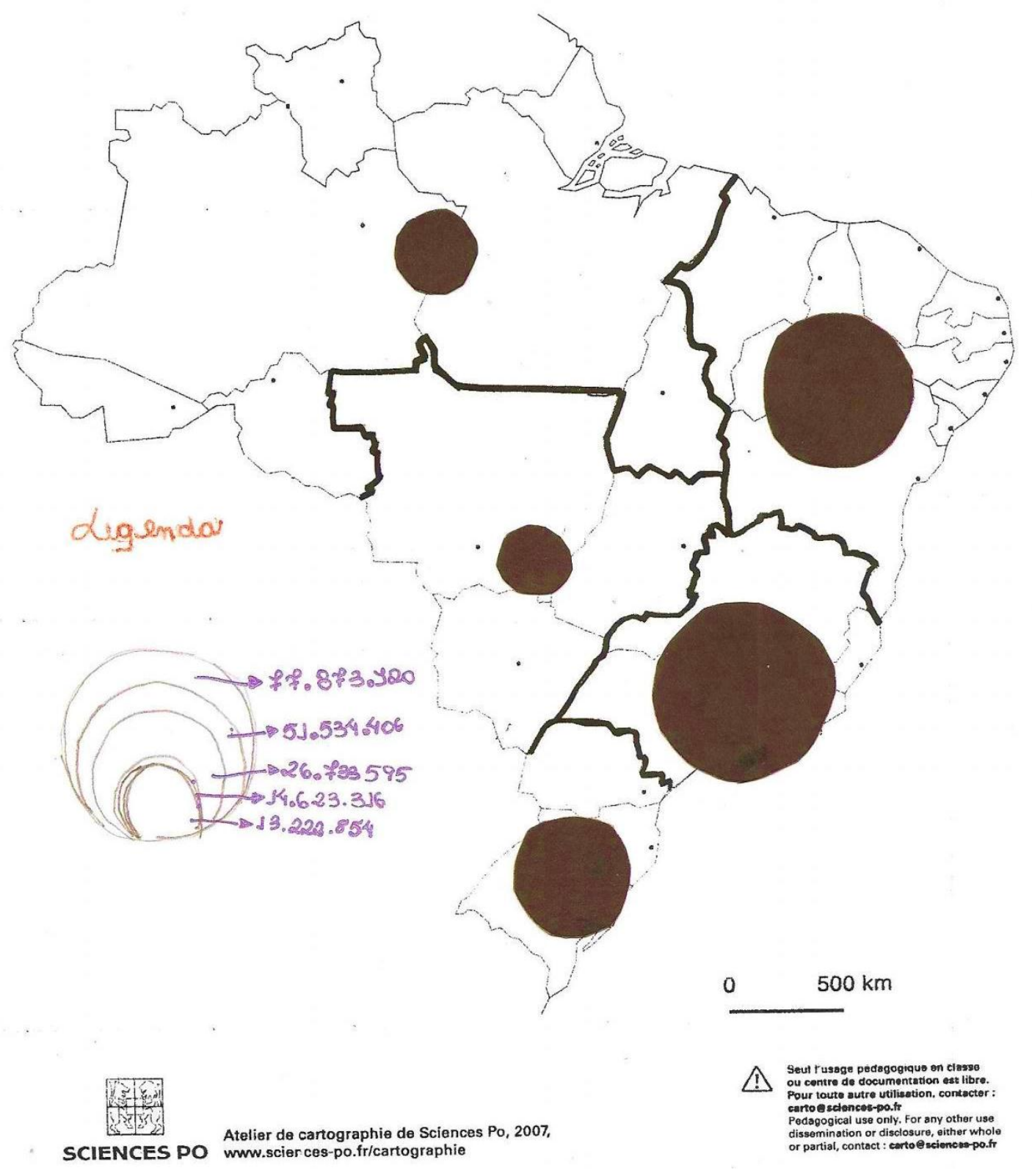

Figura 9: Mapa construído com aplicação da gramática dos mapas. Fonte IBGE, 2001. 
Os alunos construíram também um mapa de população relativa que foi utilizado na discussão de populoso e povoado junto com o mapa de população absoluta. A variável visual escolhida foi valor, o modo de implantação areolar, resultando numa representação ordenada apresentada na figura 11.

É preciso destacar que novamente, no mapa apresentado, o grupo de alunos opta por apresentar o nome das regiões, conforme se verifica no mapa com relação à região sudeste. Seria conveniente, então, para a cartografia escolar, a presença da toponímia em alguns casos?

Outro dos mapas construídos é o apresentado na figura 12. Esse mapa foi produzido por alunos do ensino fundamental regular com a variável visual valor. No caso deste mapa pode-se observar que mesmo sem a legenda a informação desejada é visível: a cor mais intensa indica onde a proporção de pessoas de idade entre 10/24 anos com rendimento de até meio salário mínimo per capita por grandes regiões é maior, e onde ela é menor, conforme indica a variação do valor da cor. $\mathrm{O}$ título do mapa colabora para explicar a visualização do fenômeno. O aprofundamento dos dados pode se dar com a intervenção do professor quando necessário. Portanto, o professor deve conhecer a gramática da representação gráfica.

O mapa produzido por alunos do ensino fundamental regular com a variável visual tamanho resultando numa representação de fluxo é apresentado na figura 13. Nesse mapa os alunos utilizaram a variável visual tamanho e variaram a espessura das setas que indicam a direção e a quantidade dos fluxos comerciais brasileiros, também, e inclusive, sem fazer cálculos para as proporcionalidades. A informação visual é suficiente para indicar que houve superávit. Os valores numéricos, quando necessários às devidas correlações podem ser verificados na legenda.

Evidencia-se que o trabalho com as tabelas permitiu levantar discussões sobre alguns dos conceitos de matemática, tais como maior, menor, valor absoluto, números inteiros, porcentagem. Além dos conceitos próprios da Geografia: regionalização, urbanização, povoado, populoso, população relativa e população absoluta, balança comercial, importação, exportação, trabalho infantil, desigualdades, exclusão, fluxo migratório, esperança de vida, globalização, e recursos minerais, sempre, adequadamente ao nível de ensino. No entanto a visualização espacial dos fenômenos só ocorreu quando os mapas ficaram prontos. 
Brasil: Trabalho infantil por região

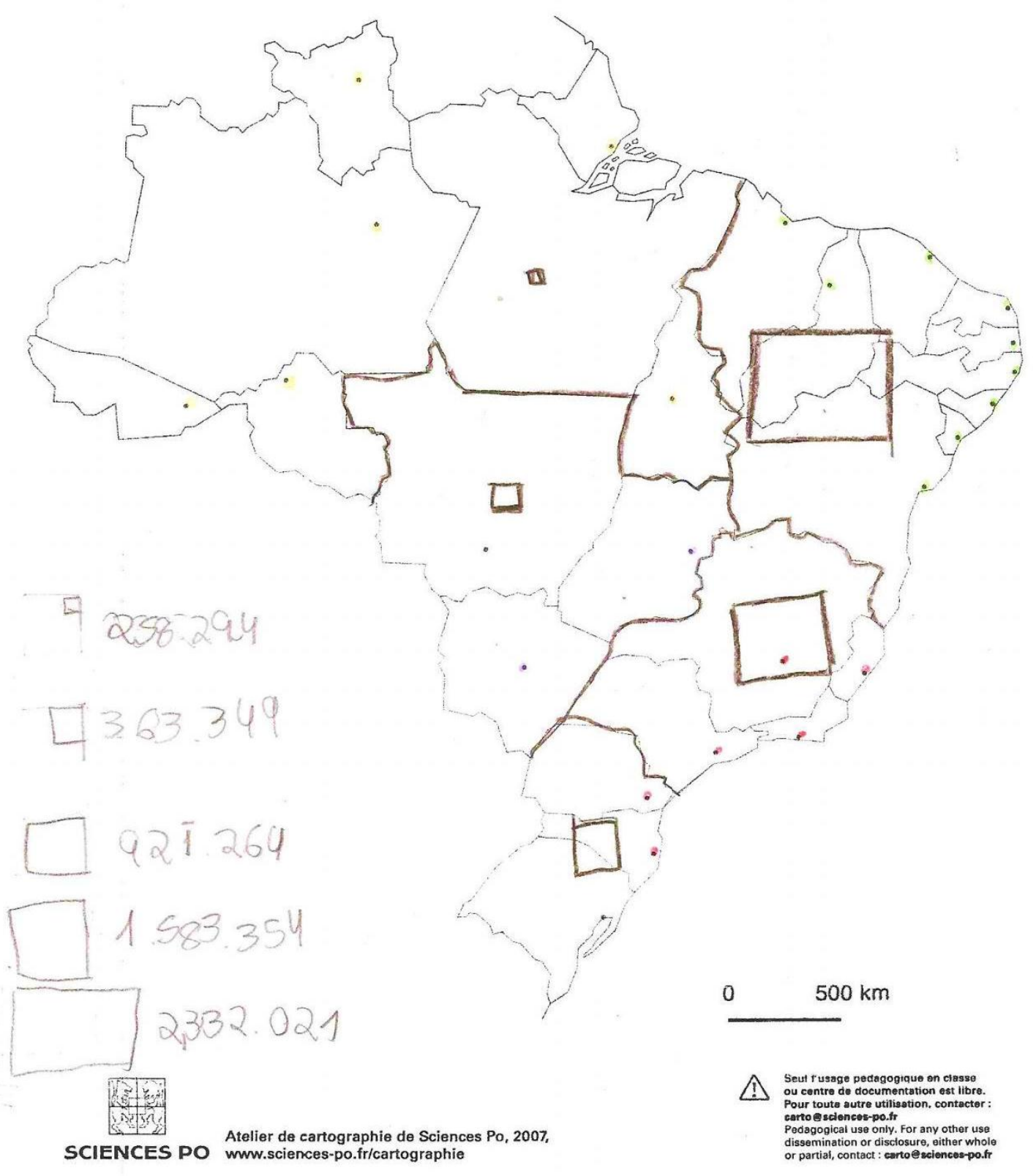

Figura 10: Mapa produzido sem cálculos de proporcionalidade. Fonte dos dados: IBGE. Pnad 1999 a 2001; BBC Brasil. Disponível em www.bbc.co.uk. Acesso em 23 de outubro de 2005. 
Brasil: População relativa

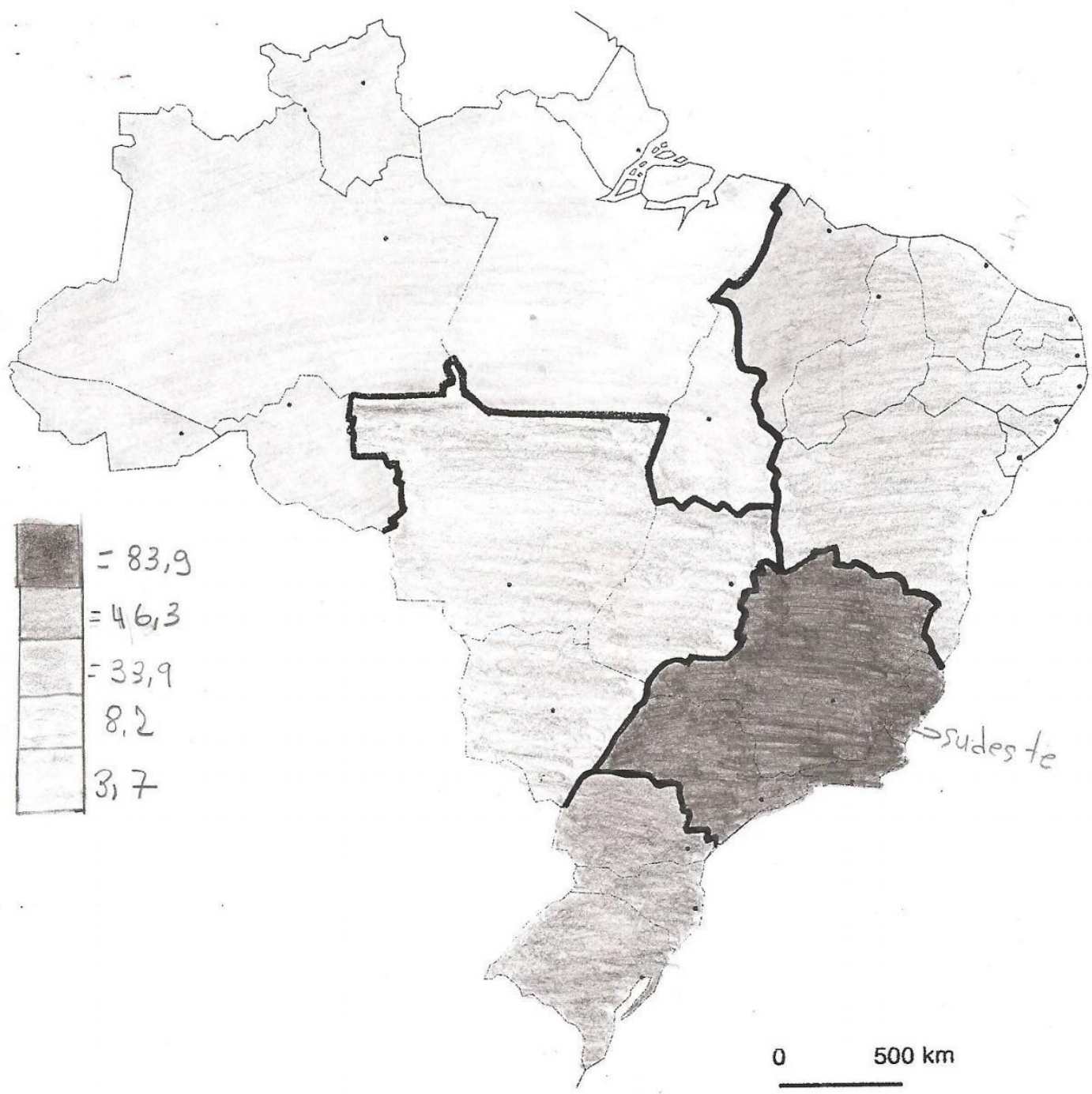

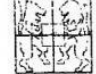
www.scier ces-po.fr/cartographie
A. Seut russge pedagogique on Classe Pour toute autre utilisetion, conkacter Pedagogical use only. For any other use Pedagogicat ise only, For any other use
dissemination or disclosure, either whol

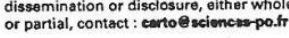

\section{dun no 5}

Figura 11: Mapa da população relativa. Fonte dos dados IBGE., 2007. 
Brasil: Proporção de pessoas de idade entre 10/24 anos - rendimento de até meio salário mínimo per capita por grandes regiões.
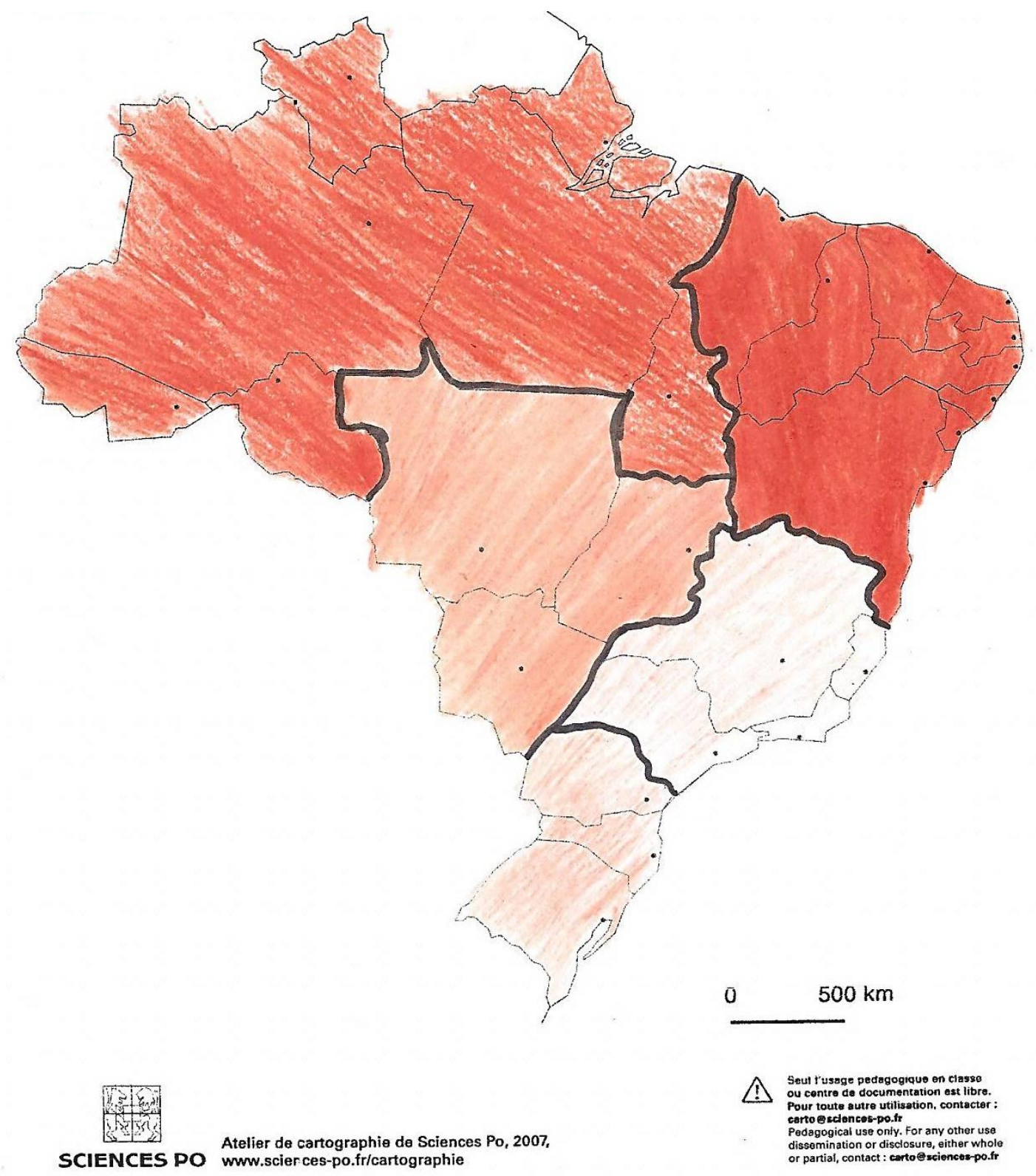

Figura 12: Mapa produzido sem legenda. Fonte dos dados IBGE, 1997.

Assim, neste ponto, pensa-se que é conveniente fazer um apanhado geral dos mapas produzidos na atividade de desafio, que é a proposta da Sequência didática número dois. Num total de 15 mapas, em dez deles os alunos descobriram que a variação do valor ou do tamanho seria conveniente. Tem-se sempre em mente que a atividade é de descoberta, e que os alunos ainda não haviam visto nada sobre 
a gramática da representação gráfica de dados. O proposto era que os alunos representassem os dados da tabela. Assim, conforme essa gramática orienta, teriam que utilizar a variável visual valor construindo um mapa que permitisse a ordenação visual da taxa de urbanização dos estados brasileiros.

Brasil: Balança comercial - 2001 .

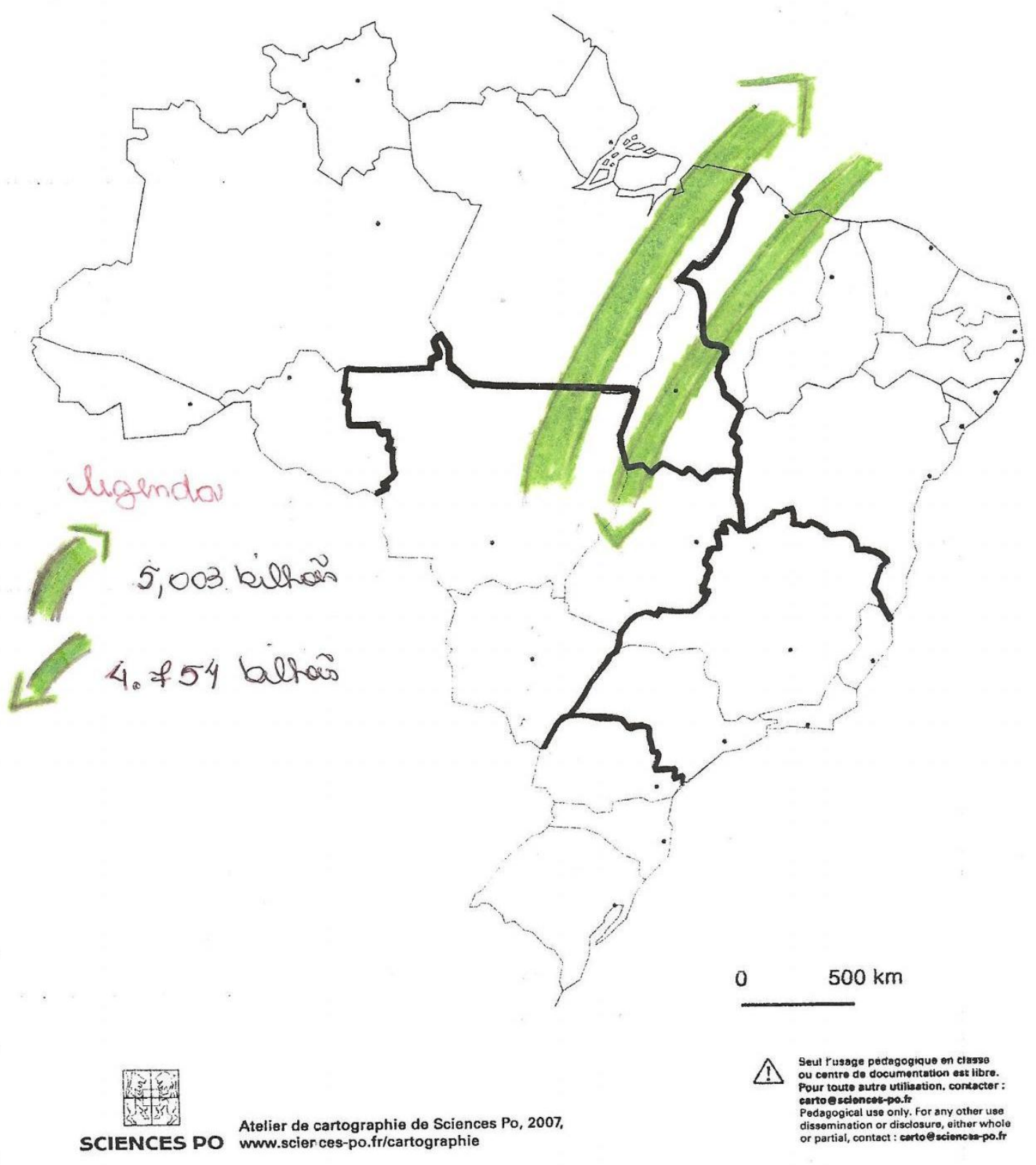

Figura 13: Mapa de fluxo. Fonte dos dados IBGE. 
A proposta é apoiada em parte das orientações de Roberto Gimeno, que afirma:

\begin{abstract}
"A criança constrói, ela mesma, os mapas a partir de uma tabela de dados ou de uma tipologia que resulta de um tratamento das informações. Esse método constitui uma abordagem original da cartografia na escola, que se inscreve no âmbito de uma pedagogia que favorece a atividade, a descoberta, a reflexão e o desenvolvimento de uma atitude de pesquisa" (GIMENO, 1991, p.106).
\end{abstract}

Nas figuras 14 e 15 apresentam-se alguns dos mapas produzidos na atividade de "desafio" proposto aos alunos de duas salas de $7^{\circ}$ ano.

O primeiro mapa, da figura 14 é um exemplo de mapa construído com base na tabela apresentada para a realização da atividade de desafio com resultado satisfatório. Os alunos descobriram sozinhos a gramática da representação gráfica. $E$, na sequência, a figura 15 é o resultado de uma tentativa de descobrir a gramática da representação gráfica. O mapa demonstra que embora os alunos não tenham conseguido formar uma imagem que fornecesse a informação sobre a taxa de urbanização visualmente, eles consideraram que para realçar os estados onde havia uma maior taxa de urbanização, o ideal seria trabalhar com uma cor de cinza intensa. Esta possibilidade é uma variável de imagem, com propriedade perceptiva ordenada, "as categorias se ordenam espontaneamente" (MARTINELLI, 2008, p.16) E o resultado das construções realizadas poderiam ser consideradas como uma afirmação espontânea dessa qualidade.

O mapa da figura 15, assim como os demais mapas construídos durante essa mesma atividade foram utilizados para que os alunos pudessem escolher, entre todos os mapas que haviam sido produzidos, aquele que respondia adequadamente onde a taxa de urbanização era maior e onde era menor. Ao que eles escolheram o mapa da figura 14.

É preciso lembrar que os alunos sempre estiveram trabalhando em grupos, e nesta atividade de desafio, em especial, as discussões entre os alunos do mesmo grupo foram bastante significativas, com todos expondo suas sugestões e argumentando para convencer os colegas de suas escolhas.

A seguir apresentam-se as figuras mencionadas acima: 
Brasil: Urbanização.

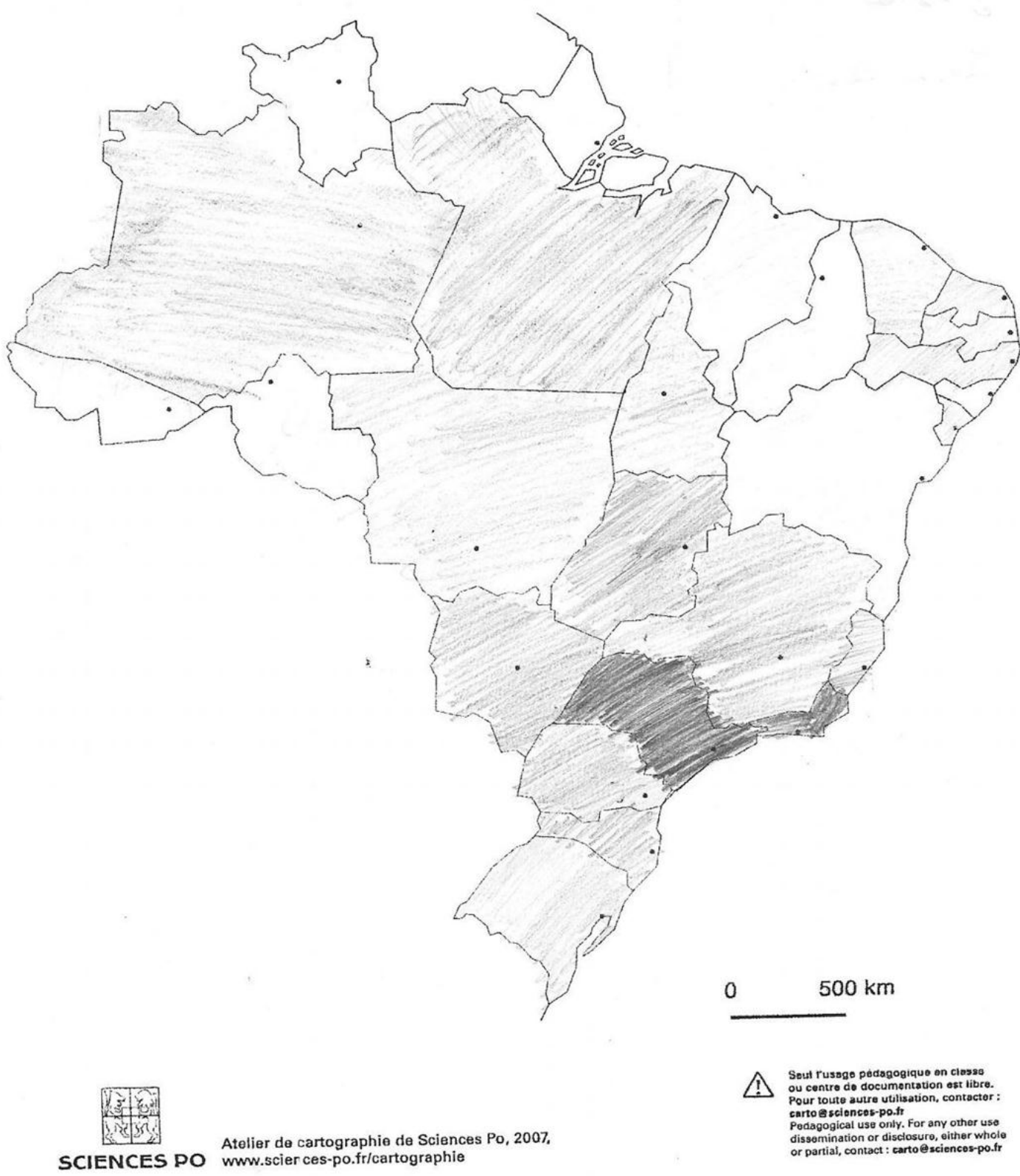

Figura 14: Mapa resultante de atividade de desafio. Fonte dos dados IBGE, 2004. 

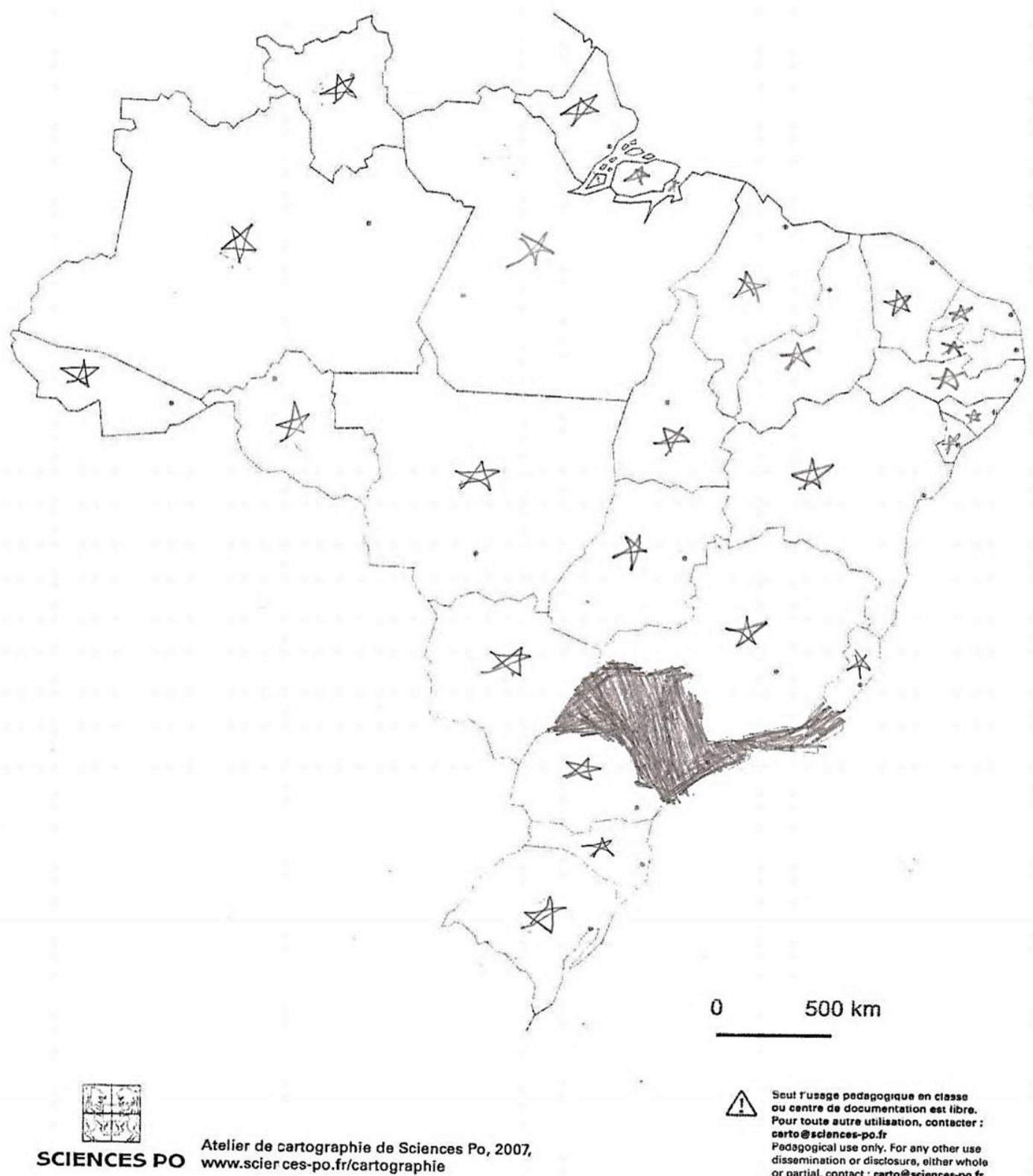

or partial, contact certoes,e elther whole

Figura 15: Tentativa de construção de mapa de urbanização.

\subsubsection{Outros mapas e possibilidades}

Uma das possibilidades surgidas durante as atividades propostas e desenvolvidas nesta pesquisa foi a oportunidade de aplicar provas, do próprio bimestre letivo, por se estar em exercício na rede pública estadual de São Paulo. Já pensando que se os alunos haviam aprendido a gramática da representação gráfica, 
eles deveriam ser capazes de fazer uma prova apenas tendo como recurso a linguagem visual.

A figura 16 traz uma dessas provas, que nos parece, evidencia o papel da cartografia para o ensino, e não só para o ensino de Geografia como uma linguagem visual.

A prova foi aplicada e já se tinha conhecimento de um aluno, o dono da referida prova, que era apenas copista. Desde os primeiros dias de aula, ao observar que ele só trabalhava com outros colegas, descobriu-se que ele não lia e nem escrevia nada, apenas conseguia copiar da lousa e do caderno de outro aluno, por este motivo ele sentava sempre junto com alguém. No dia da prova foi-lhe solicitado que copiasse as questões da lousa e em seguida, já a seu lado, foi possível acompanhá-lo no transcorrer da prova. Parte do que se pretendia avaliar era como os alunos do $7^{\circ}$ ano conseguiam manusear um atlas geográfico e extrair informações dele. Em aulas anteriores já se havia trabalhado com um atlas junto com essa sala.

O aluno em questão localizou o trecho do atlas que discutia o Brasil, identificando os contornos do território brasileiro e folheando as páginas do atlas. Conforme ele folheava o material, foram-lhe indicados quais eram os mapas com os quais ele deveria responder às questões da prova. Desse momento em diante ele conseguiu fazer a sua prova sozinho, apenas visualmente, copiando as informações das legendas, após localizar os mapas. A pergunta número 01 ele não quis responder, disse-me simplesmente que não faria. Já, com relação à pergunta número 05 ele respondeu verbalmente possibilitando a sua transcrição.

Traz-se também, na sequência, outro exemplo para que se evidenciem as qualidades dos trabalhos com mapas.

Ainda para destacar o papel da cartografia como linguagem visual ideal para o ensino de Geografia, apresenta-se o mapa da figura 17, que foi construído por um aluno da Educação de Jovens e Adultos (EJA). O que havia sido proposto à sua turma era a construção de um mapa ordenado, sob o título "Brasil: Exportações por região". Eles deveriam trabalhar em grupo, mas como esse aluno sempre apresentava bastante dificuldade de aprendizagem os colegas o aceitavam no grupo, mas não trocavam informações com ele. No dia desse trabalho especificamente ele me perguntou se poderia fazer outro mapa uma vez que ninguém queria mesmo trabalhar com ele, ele gostaria de trabalhar sozinho. Eu 
concordei. Ele me pediu para construir um mapa das regiões. Como o mapa base já estava dividido nas cinco grandes regiões, ele me perguntou: Se eu escolher o signo que eu acho que separa a senhora me fala o nome da região? Então ele pintou cada região de uma cor diferente e montou a legenda conforme lhe informava os nomes correspondentes a cada cor, assim que terminou de pintar.

Prova bimestral - 6ª série

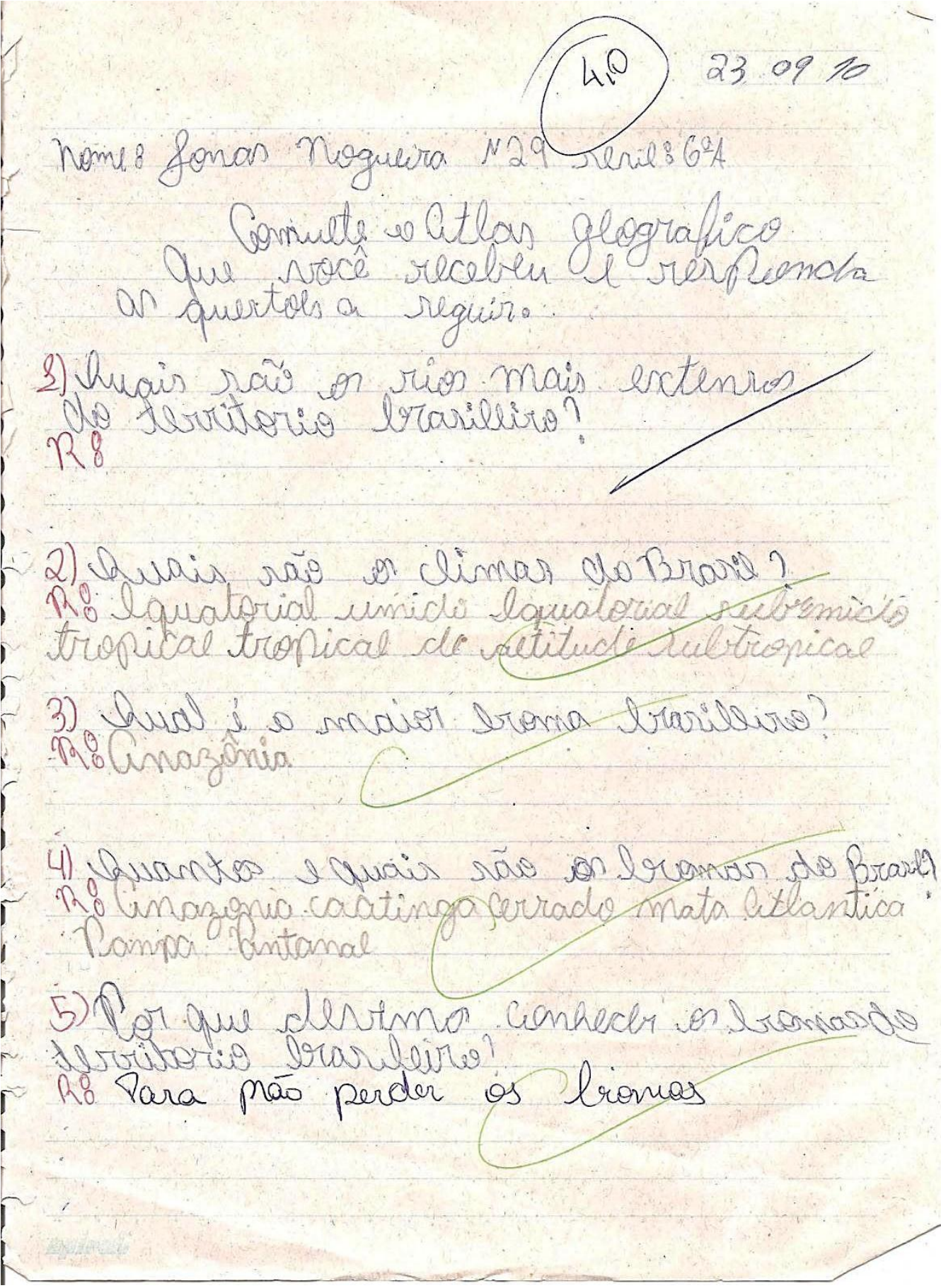

Figura 16: Prova bimestral, 6ª série: aplicação da cartografia como linguagem visual. 
Brasil: Grandes regiões IBGE.

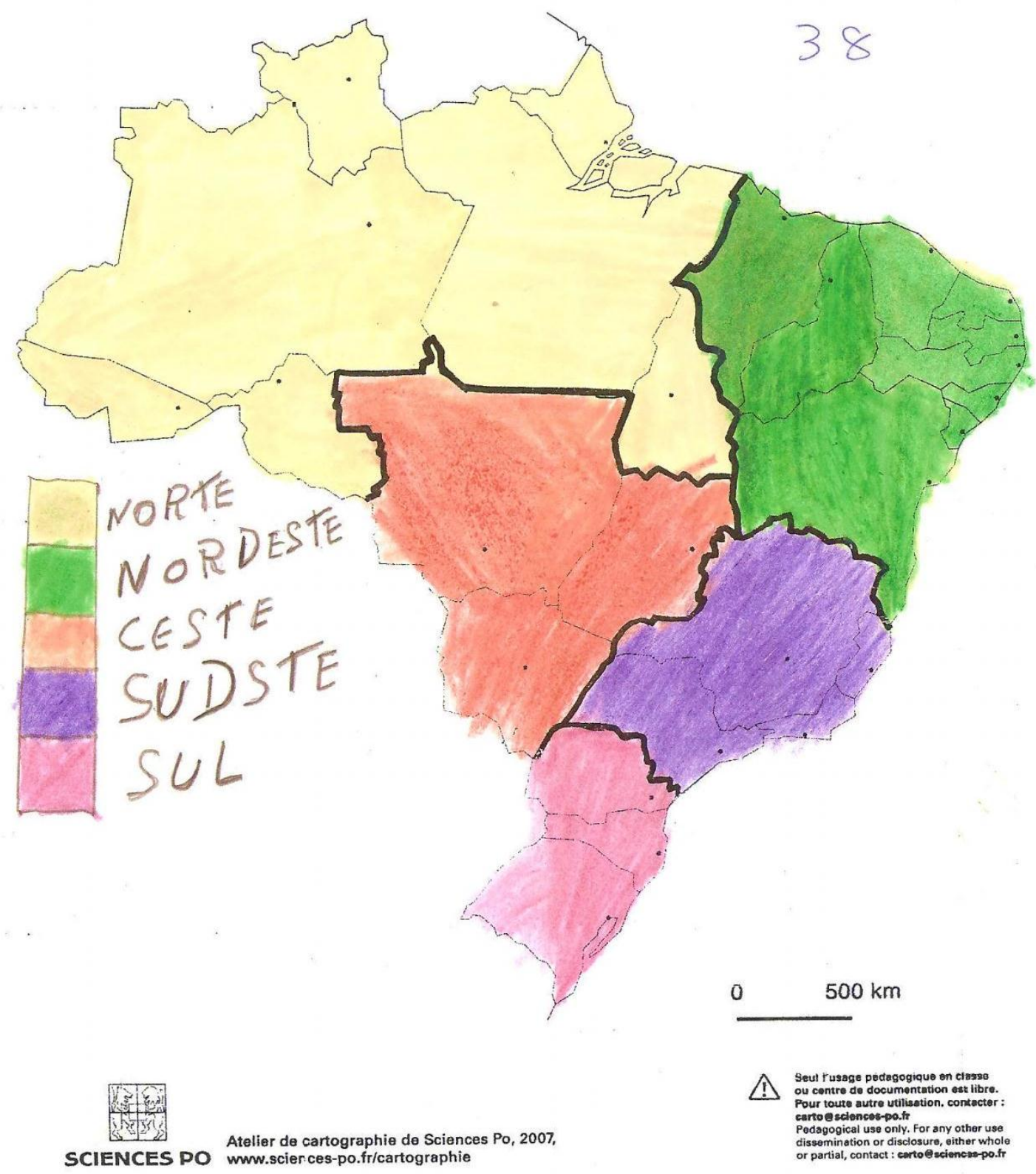

Figura17: Mapa construído por aluno da EJA

E ainda, é necessário também destacar alguns aspectos, como os discutidos sobre os mapas das figuras 18 e 19. São mapas produzidos pelos alunos, e que, ou não cumpriram criteriosamente as orientações dadas segundo a gramática da 
representação gráfica sob a Semiologia gráfica, ou que evidenciaram dificuldades em outras disciplinas, o que poderia dificultar a aquisição de conhecimentos em Geografia.

Com relação aos mapas que apresentaram resultado insatisfatório, destacamse os das figuras 18 e 19, que são exemplos.

$\mathrm{Na}$ figura 18 o mapa apresentado é analisado frente às dificuldades dos alunos nas atividades realizadas. Entende-se que é necessário tecer comentários sobre cada um deles oportunamente. Ressaltar, inclusive que as atividades foram pensadas para permitir que o aluno adquirisse conhecimentos geo-cartográficos por intermédio da construção de mapas pela aplicação da gramática da representação gráfica. Assim, o processo de aprendizagem foi considerado no todo.

O mapa da figura 18 foi produzido por alunos do ensino médio EJA. Os alunos confundiram-se, inclusive, na ordenação dos dados para três, das cinco regiões, como apontado no próprio mapa. Embora a ordem da legenda apresente certa ordem visual, no mapa essa ordem não aparece. É visível apenas a hierarquia dos dados entre a região Sudeste e a região Sul. Há uma falsa imagem, uma inversão da informação, portanto um erro cartográfico.

Ainda nessa direção é preciso apresentar o mapa da figura 19. Esse é um mapa construído por alunos do ensino médio EJA. Este mapa evidencia a necessidade de nomear as regiões, o que pode ser entendido como uma insegurança dos alunos do grupo em localizar mentalmente as regiões administrativas do Brasil, segundo o Instituto brasileiro de Geografia e estatística (IBGE). Essa segurança só se estabelece se os nomes das regiões forem colocados na legenda junto com os dados numéricos. Com relação à linguagem visual observase um ruído visual, o ideal seria colocar no título a informação: porcentagem.

Esclarece-se, em tempo, que por se tratar de uma pesquisa que procura discutir a linguagem visual, buscou-se também apresentar no próprio corpo do texto a discussão realizada e apresentada em texto verbal- sequencial juntamente com os mapas, apresentados como linguagem visual, com a finalidade de que fosse possível a visualização imediata dos mapas e das atividades realizadas, possibilitando a análise dos resultados e do trabalho de um modo geral.

Entende-se que a proximidade dos textos verbais e dos textos visuais facilita a acessibilidade a qualquer informação que for necessária para a interpretação deste trabalho, imediatamente, e neste caso, diferentemente da utilização da 
cartografia como linguagem visual em aulas, o texto verbal sequencial é o polo consistente do discurso.

Mapa: Brasil: Exportação por região.

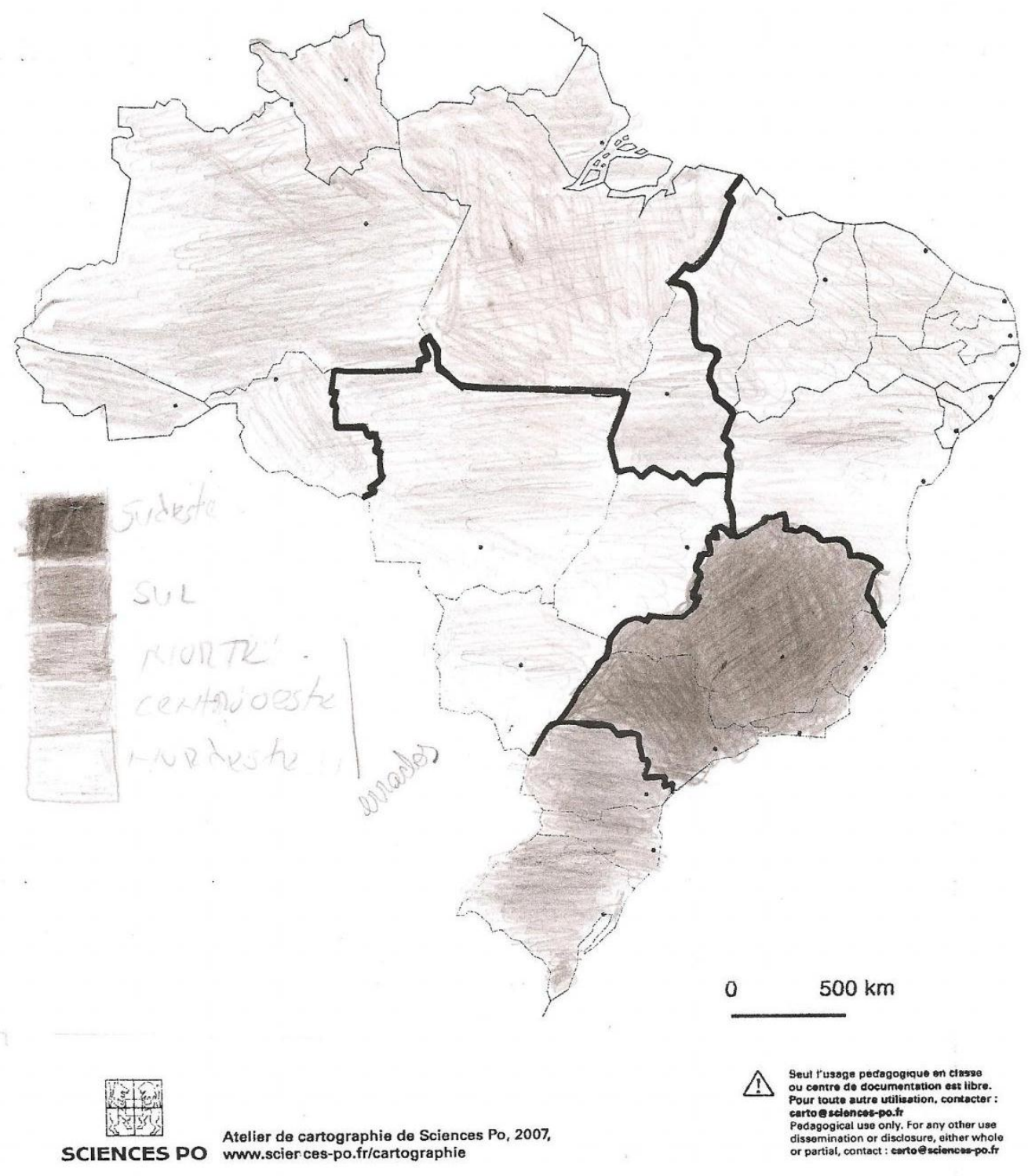

Figura 18: Mapa com resultado insatisfatório I, produzido por alunos do ensino médio EJA. 
Brasil: Exportação por região.

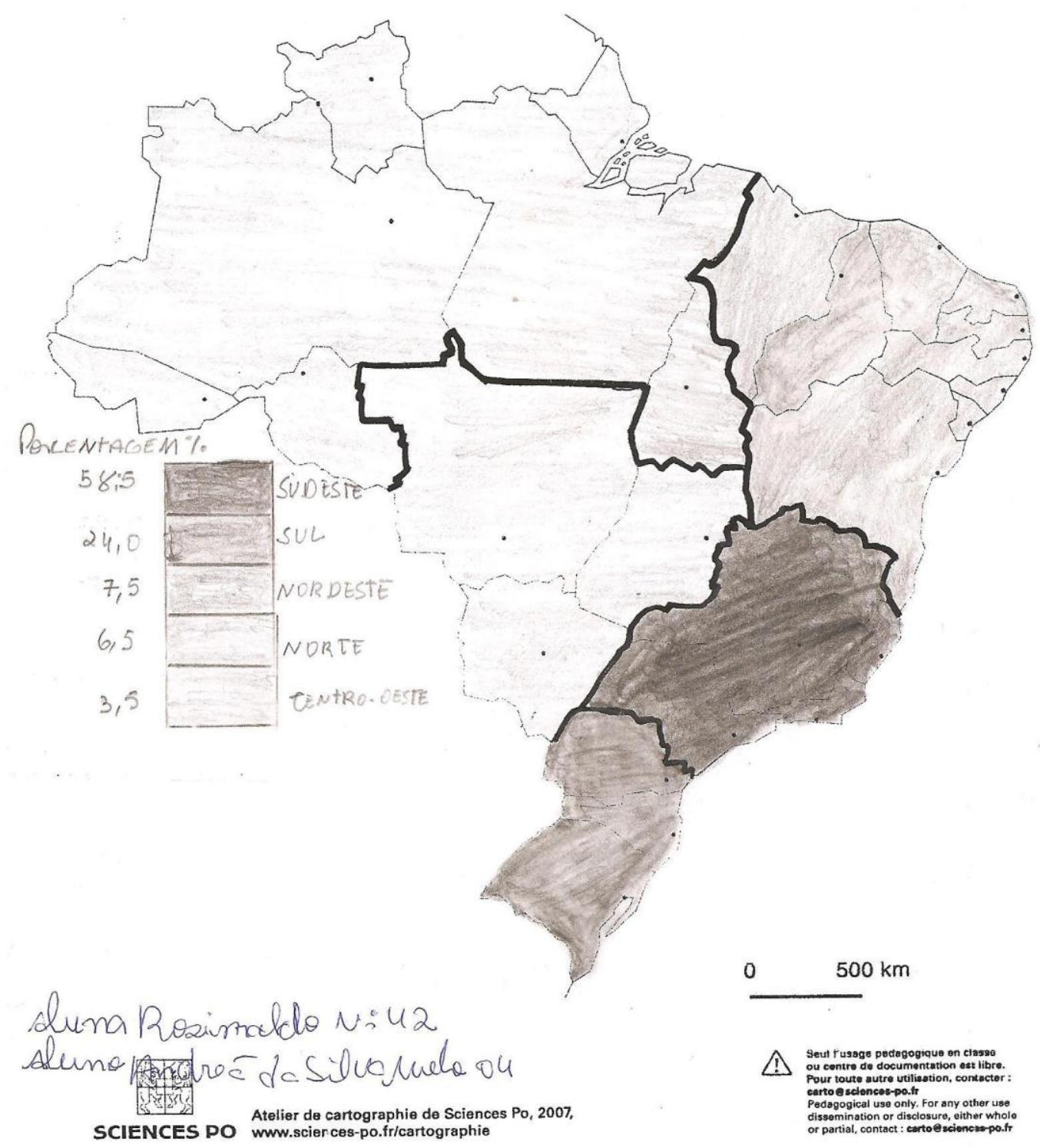

Figura 19: Mapa com resultado insatisfatório II.

E, finalmente, apresentam-se algumas fotos de alunos durante as atividades. A coleção de fotos apresentada na figura 20 traz os alunos em diversas atividades realizadas, desde a atividade diagnóstica até nas atividades de construção dos mapas. 


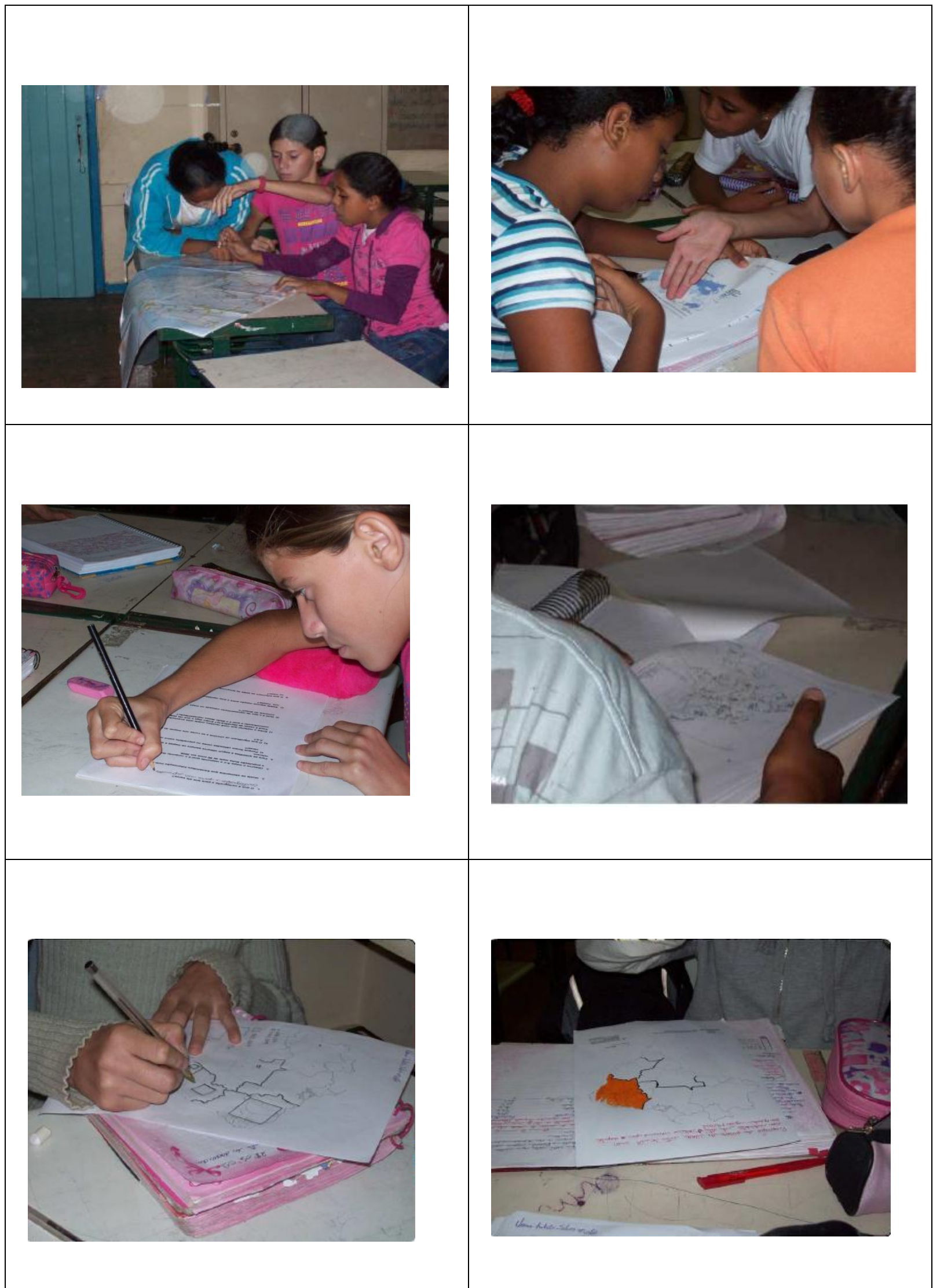

Figura 20: Alunos em atividade diagnóstica e de construção de mapas. 


\section{CONCLUSÕES FINAIS}

Mapas que funcionam como linguagem visual poderiam ser amplamente utilizados no ensino de uma Geografia preocupada com os processos de renovação. O fato é que ao ensinar a gramática da representação gráfica, ensina-se a linguagem cartográfica. Os conteúdos geográficos, portanto a linguagem geográfica pode ser apreendida por uma coerência entre essas duas linguagens em sala de aula.

Entende-se que atividades cartográficas orientadas pela gramática da representação gráfica e, principalmente aquelas que levem os alunos a resolverem questões relativas às construções de mapas temáticos, ou seja, que tragam necessidades de resolução de problemas, e que, portanto façam com que ocorram ganhos cognitivos para os alunos, devem estar constantemente nas aulas de Geografia. E neste item, incluam-se as atividades que utilizam a gramática da representação gráfica para a produção de mapas temáticos pelo menos.

Ressalta-se que a linguagem cartográfica além de ser ensinada deve permanecer desde as séries inicias, a partir do ciclo II do ensino fundamental até o final do ensino médio no currículo escolar, em todas as séries. A finalidade é fazer com que os mapas temáticos façam sentido para os alunos, uma vez que, como linguagem, possuem um potencial comunicativo relevante no ensino e na aprendizagem. Observa-se que se vive num mundo onde a força da imagem é muito significativa. Mapas são encontrados em diversos lugares e materiais, desde painéis, outdoors, telejornais, e na internet. $O$ aluno deve saber lê-lo, ver as informações de maneira crítica, inclusive. O mapa, se utilizado como linguagem visual, possibilita a efetivação do processo de ensino e aprendizagem dos conteúdos geo-cartográficos.

Entende-se inclusive, que é imperativo pensar em como os mapas para escolares poderiam colaborar para a explicitação do espaço geográfico como societal. Neste caso é preciso considerar que uma possibilidade para a renovação da Geografia escolar seriam as anamorfoses. As opções de construção das 
anamorfoses são muitas frente ao uso dos computadores e softwares. Mas, também existe a possibilidade de se começar a introduzir as questões sobre anamorfoses mesmo no ensino fundamental, ao trabalhar com figuras geométricas proporcionais, que podem ser construídas manualmente. E, principalmente nas escolas públicas, onde o acesso à internet não é tão adequado quanto o pretendido.

Com relação aos mapas em sala de aula pouco ou nada sobre esse espaço, tem sido representado pelos mapas que chegam ou que são produzidos nela.

Anamorfoses e mapas construídos conforme a gramática da representação gráfica expressam uma linguagem visual, visto que a comunicação se dá de forma atemporal e não sequencial.

Sugerir-se-ia que as possibilidades de renovação, como as discussões teóricas sobre as anamorfoses, mas também e inclusive, a gramática da representação gráfica deveriam ser pensadas para a formação dos professores, no âmbito acadêmico. Finalmente, evidencia-se inclusive, a necessidade de os professores que já estão em exercício conhecerem-nas para, pelo menos, poder orientar trabalhos em sala de aula na leitura desse material para a interpretação de mapas construídos nas bases de uma renovação.

Assim, numa relação dialética entre as linguagens geográfica e cartográfica, os alunos desenvolveriam habilidades e competências na aquisição dos conhecimentos geo-cartográficos.

Evidenciando o processo de ensino e aprendizagem os trabalhos com mapas podem colaborar para enriquecer as atividades em sala de aula de Geografia.

Entende-se, inclusive, que nesse processo há um limite nas relações estabelecidas entre professor e aluno. Ao professor cabe tomar todo o cuidado com o que e como ensinar, e aqui entram tanto o currículo como as atividades didáticas, em especial os trabalhos com mapas. Portanto haveria a necessidade de o professor conhecer para poder aplicar a gramática da representação gráfica. $O$ fato é que cabe a ele preparar o contexto de sala de aula o mais adequadamente possível a cada público alvo e para cada situação de aprendizagem. Mas, e então, seria esse o seu limite.

Com relação ao aluno, caberia a ele interagir com professor e conteúdos, para poder aprender, mas, o seu desenvolvimento cognitivo deve permitir. Portanto haveria limitações no processo. $O$ desejável seria que o processo se efetivasse. Mas, nem só professor, assim como nem só o aluno, e nem mesmo ambos 
trabalhando juntos podem ultrapassar certos limites impostos pelos contextos mais gerais que os limitam.

Outra prerrogativa dos trabalhos com a gramática da representação gráfica são os trabalhos em grupo. Estes podem levar ao desenvolvimento cognitivo dos alunos, pois realmente eles trocam informações, fazem sugestões, apresentam seus pontos de vista e conseguem produzir bons mapas. No entanto, os trabalhos em grupo não garantem a participação ativa de todos os seus membros. Afirma-se ainda considerar que a interação social nem sempre parece ter efeitos positivos nos trabalhos em grupo, e seria apenas uma possibilidade.

Poder-se-ia destacar ainda que quando os alunos conhecem a gramática e sabem "ver" as informações visuais presentes nos mapas, além de ganhos cognitivos pode-se falar em ganhos afetivos na relação professor-aluno, o que seria benéfico ao processo de ensino e aprendizagem.

Afirma-se ainda que a efetivação de trabalhos bem elaborados pelo professor com mapas temáticos poderia facilitar a avaliação de alunos que apresentam problemas de aprendizagem da linguagem verbal. Um aluno que ficaria com uma avaliação muito baixa em outra situação com utilização unicamente da linguagem verbal sequencial, poderia ser mais bem avaliado por intermédio da utilização concomitante da cartografia enquanto linguagem visual. Assim, os trabalhos com mapas poderiam ser também um recurso para as atividades de recuperação contínua e paralela. A autoestima desse aluno melhoraria significativamente após essa atividade. Ele, sentindo-se capaz de ler e construir mapas temáticos passaria a se interessar mais pelas aulas de Geografia.

Evidencia-se que as atividades realizadas no sentido de "descobertas", desafios feitos aos alunos para descobrirem sozinhos a gramática da representação gráfica tornam as aulas de Geografia mais estimulantes. O que se propõe é levar os alunos a investigarem por si mesmos, a partir do quadro das variáveis visuais, quais seriam as variáveis visuais mais adequadas para demonstrar uma ordenação, ou a diversidade ou a quantidade dos fenômenos que precisam representar.

As atividades com mapas permitem inclusive, que se trabalhe com textos que utilizam a linguagem verbal sequencial e tabelas. O que se mostra adequado para o desenvolvimento de habilidades e competências necessárias para leitura, ordenação, e interpretação da linguagem verbal textual, também presente na tabela, mesmo antes de produzir os mapas. 
Conclui-se que a Cartografia é um recurso para o ensino de Geografia que deve ser assumida como uma ferramenta de trabalho produtiva e, portanto necessária. Cabe ao professor de Geografia, ou a todos os profissionais que utilizarem o mapa no ensino e na aprendizagem, fazê-lo como uma linguagem visual monossêmica.

Limites existem, mas devem ser vistos como desafios a serem vencidos. Nesse sentido a certeza do inacabamento, da busca constante pelo aprendizado deve ser a única certeza do professor. E a gramática da representação gráfica, aplicada corretamente na construção e leitura de mapas nas aulas de Geografia pode colaborar nesse sentido. 
BIBLIOGRAFIA

ALMEIDA, Rosângela Doin de. (org.) Cartografia escolar. 1 ed., São Paulo: Contexto, 2008.

ALMEIDA, Rosângela Doin de. Uma proposta metodológica para a compreensão de mapas geográficos. In: (org.) Cartografia escolar. $1^{\underline{a}}$ ed., São Paulo: Contexto, 2008.

AMARAL, Ana Lúcia. Significados e Contradições nos processos de formação de professores. In: DALBEN, Ângela. DINIZ, Julio. LEAL, Leiva. SANTOS, Lucíola (orgs.). Convergências e tensões no campo da formação e do trabalho docente: Didática, Formação de Professores, Trabalho Docente. XV ENDIPE. L-4. Belo Horizonte: Autêntica, 2010.

ANTAS Jr. Ricardo Mendes. ANTAS JR, R. M. . Uma geografia do lazer paulistano. In: CAMARGO, Ana Maria de Almeida. (Org.). Curso de História de São Paulo vol. III, 2008.

ASBAHR, Flávia da Silva Ferreira. A pesquisa sobre a atividade pedagógica: contribuições da teoria da atividade. Rev. Bras. Educ., Ago. 2005, no 29, p.108-118.

ATLAS, Geográfico Escolar. São Paulo: IBEP, 2008.

BERTIN, Jacques. O teste de base da representação gráfica. Revista brasileira de Geografia. Rio de Janeiro, n. 42, v. 01, p. 160-182, jan./mar.1980.

BERTIN, Jacques. GIMENO, Roberto. A lição da Cartografia na escola elementar. Boletim Goiano de Geografia, n 2, v.1, jan./jun. 1982. p. 35-56.

BERTIN, Jacques. A Neográfica e o tratamento gráfico da informação. Tradução de Jayme A. Cardoso. Curitiba: ed. UFPR, 1986. 273p.

BERTIN, Jacques. Ver ou Ler. Seleção de textos (AGB), Trad. Margarida M. de Andrade. São Paulo, n. 18, p.45-62, maio 1988.

BOARD, Christopher. Os mapas como modelos. In: CHORLEY, Richard J. e HAGGETT. Peter (Org.). Modelos físicos e de informação em Geografia. Rio de Janeiro: Livros Técnicos e Científicos / Ed. Da Universidade de São Paulo, 1975. p. 139-184.

BRAGA, Rosalina Batista. Ensino de Geografia: Convergências e Tensões no Campo da Formação e do trabalho docente. In: SANTOS, Lucíola Licínio de Castro Paixão DALBEN, Ângela. DINIZ, Júlio. LEAL, Leiva. Convergências e tensões no campo da formação e do trabalho docente.- XV ENDIPE - L-6. Belo Horizonte : Autêntica, 2010.

BRASIL. Exame Nacional do ensino médio - ENEM. Brasília: Ministério da Educação. Disponível em < http://www.inep.gov.br/enem> acesso em 10/12/2010.

BROUSSEAU, Guy. Introdução ao estudo da teoria das situações didáticas: conteúdos e métodos de ensino. Trad. Camila Bogéa. São Paulo: Ática, 2008.

CALLAI, Helena Copetti. Projetos Interdisciplinares e a formação do professor em serviço. In: Geografia em perspectiva, São Paulo: Contexto, 2002. 
CARVALHO, Mônica de. Cidade Global: anotações críticas sobre um conceito. Disponível em < http://www.scielo.br/pdf/spp/v14n4/9753.pdf> acesso em 06/12/2010.

CASTI, Emanuela. Cartographie. In: LÉVY, Jacques; LUSSAULT, Michel (Org.). Dictionnaire de la Géographie et de l'espace des societies. Paris: Belin, 2003. P.134-135. Tradução de trabalho de Fernanda Padovesi Fonseca e Jaime Tadeu Oliva.

CASTROGIOVANI, Antônio Carlos. O misterioso mundo que os mapas escondem, In Cadernos do Aplicação, v. 08, № 2, jul./dez. UFRGS - Faculdade de Educação, Colégio de aplicação. Porto Alegre: 1995.

CAUVIN, Colette, Transformações cartográficas espaciais e anamorfoses. In: DIAS, Maria Helena (Coord.) Os mapas em Portugal: da tradição aos novos rumos da cartografia. Lisboa: Cosmos, 1995. P. 267-310.

CAVALCANTI, Lana de Souza. Cotidiano, Mediação pedagógica e formação de conceitos: Uma contribuição de Vygotsky ao ensino de Geografia. In: Cad. Cedes, Campinas, vol. 25, $\mathrm{n}^{\circ}$ 66, p. 187-207, maio/ago. 2005. Disponível em http://www.cedes.unicamp.br . acesso em 15/03/2010.

CHAPELON, Laurent. Accesibilidad. Disponível em: $<$ http://hypergeo.free.fr/article.php3?id_article=128> acesso em: 03/03/2006

CORTELLA, Mário Sérgio. A escola e o conhecimento: Fundamentos epistemológicos e Políticos. 9ª ed. São Paulo: Cortez, Instituto Paulo Freire, 2005.

DANIELS, Harry. Vygotsky e a Pedagogia, São Paulo: Loyola, 2003.

DURAND, Marie-Françoise. Geografia e Relações Internacionais: globalização, territórios e redes na perspectiva da escola geográfica francesa. Caderno $\mathbf{C R H}$, Salvador, v. 19, n.48, p.431-444, set./dez. 2006.

DURAND, Marie-Françoise et al, Atlas da Mundialização: compreender o espaço mundial contemporâneo. São Paulo: Saraiva, 2009.

FERREIRA, Aurino Lima. ACIOLY-RÉGNIER, Nadja Maria. Contribuições de Henri Wallon à relação cognição e afetividade na educação. Educar, Curitiba: Editora UFPR. n. 36, p. 21-38, 2010.

FONSECA, Fernanda Padovesi; OLIVA, Jaime Tadeu. A Geografia e suas linguagens: O caso da Cartografia. In CARLOS, Ana Fani Alessandri (org.) A Geografia na sala de aula. São Paulo: Contexto, 2002. p. 62-78.

FONSECA, Fernanda Padovesi. A inflexibilidade do espaço cartográfico, uma questão para a Geografia: análise das discussões sobre o papel da Cartografia. Tese (doutorado em Geografia), FFLCH - USP, 2004. 250 p.

FONSECA, Fernanda Padovesi. O Potencial Analógico da Cartografia. Boletim Paulista de Geografia, São Paulo, n. 87, p.85-110, 2007.

FONTANABONA, Jacky. Langage cartographique et connaissances géographiques. $\quad \mathrm{http} / / /$ ecehg.inrp.fr//ECEHG/enseigner-apprendre/langagecartographique/langagecartographique-fontanabona-pdf.pdf. Acesso em 10/11/2009. Tradução nossa. 
FREIRE, Paulo. Pedagogia da autonomia: saberes necessários à prática educativa. 31를. Ed̃o Paulo: Paz e Terra, 1996.

GARNIER, Catherine. BEDNARZ, Nadine. ULANOVSKAYA, Irina. (orgs.) Duas diferentes visões da pesquisa em Didática, In: Após Vygotsky e Piaget, perspectivas social e construtivista, escolas russa e ocidental. Trad. Eunice Gruman. Porto Alegre: Artes Médicas, 1996, p.11-25.

GIMENO, Roberto. Uma abordagem da Cartografia na escola elementar. Boletim Goiano de Geografia. N.1, v.1, p.104-125, jan./dez. 1991.

GRUPO INVESTIGACIÓN EN LA ESCUELA. Proyecto Curricular "Investigación y Renovación Escolar" (IRES). (Versión provisional). Sevilla: Díada, 1991.

HARLEY, J.B. Textos e contextos en la interpretación de los primeros mapas. In: La nueva naturaleza de los mapas: Ensayos sobre la historia de la cartografía. México: Fondo de Cultura Económica. 2005. P.59-77.

JOLY, Fernand. A Cartografia. São Paulo: Papirus, 1990.

LACASA, Pilar. La escuela: ¿uma sociedade dentro de outra? In: Aprender em la escuela, aprender em la calle. Madri: 1994, 384 p.

LEOENTIEV, Alexis. O desenvolvimento do Psiquismo. São Paulo: Livros Horizonte, 1978.

LEONTIEV, Alexis N. Uma contribuição à Teoria do Desenvolvimento da Psique Infantil. In: VIGOTSKII, L. S., LURIA, A. R., LEONTIEV, A. Linguagem, Desenvolvimento e Aprendizagem. Trad. Maria da Penha Villalobos. São Paulo: Ícone Editora e EDUSP, 1988, 228p.

LE SANN, Janine Gisele. Mapa: Um instrumento para apreender o mundo. Revista Geografia e ensino, Belo Horizonte: v.6, n.1, p.25-30. Mar.1997.

LE SANN, Janine Gisele. Dar o peixe ou ensinar a pescar? Do papel do atlas escolar no ensino fundamental. Revista Geografia e ensino, Belo Horizonte: v.6, n.1, p.3134. Mar.1997.

LE SANN, Janine Gisele. Metodologia para introduzir a Geografia no ensino fundamental. In: ALMEIDA, Rosângela Doin de. Cartografia escolar. São Paulo: Contexto, 2008.

LE SANN, Janine Gisele. Ensinar no século XXI - Uma proposta metodológica para a Geografia. VI Colóquio de Cartografia para Crianças e Escolares e II Fórum Latinomaericano de Cartografia para Escolares, 2009. $<$ http://cartografiaescolar.blogspot.com/2009/08/vi-coloquio-de-cartografiapara.html> acesso em 10/01/2011.

LEVY, E. Democracia nas cidades globais: um estudo sobre Londres e São Paulo. São Paulo, Studio Nobel, 1997.

LÉVY, Jacques e LUSSAULT, Michel (org.). Espace. In: Dictionnaire de la Géographie et de l'espace des sociétés. Paris: Belin, 2003. p. 325-333. Tradução de trabalho de Monica Balestrin Nunes, jul./2009 com comentários de Jaime Tadeu Oliva.

LÉVY, Jacques. Uma virada cartográfica? In: ACSELRAD, Henri (org.). Cartografias sociais e território. Rio de Janeiro: UFRJ/IPPUR, 2008. p.153-167. 
LIBÂNEO, José Carlos. A aprendizagem escolar e a formação de professores na perspectiva da psicologia histórico-social e da teoria da atividade. Educar, Curitiba, n. 24, p. 113-147, 2004. Editora UFPR. Disponível em http://ojs.c3sl.ufpr.br/ojs2/index.php/educar/article/view/2211/1854. acesso em 13/03/2010.

LIBÂNEO, José Carlos. Produção de saberes na escola: suspeitas e apostas. Disponível em: <http://www.educacaoonline.pro.br/art_producao_de_saberes.asp.>. Acesso em 20 mar. 2004.

LIBÂNEO, José Carlos. A didática e a aprendizagem do pensar e do aprender: A teoria histórico-cultural da atividade e a contribuição de Vasili Davydov, Revista brasileira de Educação. Set /Out /Nov /Dez 2004 № 27, http;//www.anped.org.br/rbe/rbedigital/RBDE27/RDBE27/_03_JOSE_CARLOS_LIBÂ NEO.pdf. Acesso em 26/11/2008

LUSSAULT, Michel. Image. In: LÉVY, Jacques. LUSSAULT, Michel (org.). Dictionaire de la Géographie et de I'espace des societies. Paris: Belin, 2003. P.485-489. Tradução de trabalho de Fernanda Padovesi Fonseca e Jaime Tadeu Oliva.

MARTINELLI, Marcello. Curso de Cartografia temática. São Paulo: Contexto, 1991, $180 \mathrm{p}$.

MARTINELLI, Marcello. Gráficos e Mapas: construa-os você mesmo. São Paulo: Moderna, 1998, $120 \mathrm{p}$.

MARTINELLI, Marcello. Mapas da Geografia e Cartografia temática. 4 ed. São Paulo: Contexto, 2008.

MARTINELLI, Marcello. A sistematização da Cartografia temática. In: ALMEIDA, Rosangela Doin de (org.). Cartografia escolar. São Paulo: Contexto, 2008. p.193220.

MOREIRA, Marco Antônio. A organização do ensino à luz da teoria da aprendizagem significativa, nas perspectivas de Ausubel, Novak e Gowin. In: MOREIRA, Marco Antônio. A Teoria da aprendizagem significativa e sua implementação em sala de aula. Brasília: Ed. Universidade de Brasília. 2006.

NÓVOA, Antônio. Formação de professores e profissão docente. In: NÓVOA, A. Os professores e sua formação. Lisboa: D. Quixote, 1992, p. 15-33.

OLIVA, Jaime T. O espaço geográfico como componente social. Rev. Terra Livre. São Paulo: 2001, n. 17 , p. 25-48, $2^{\circ}$ semestre.

OLIVA, Jaime T. Ensino de Geografia: um retardo desnecessário. In CARLOS, Ana Fani A. (org.) A Geografia na sala de aula. São Paulo: Contexto. 2002. p. 34-49.

OLIVEIRA, Lívia de. Estudo metodológico e cognitivo do mapa. In: ALMEIDA, Rosangela Doin de (org.). Cartografia escolar. São Paulo: Contexto, 2008. p. 1541.

PAGANELLI, Tomoko lyda. Para construção do espaço geográfico da criança. In: ALMEIDA, Rosângela Doin. Cartografia escolar. São Paulo: Contexto, 2008.

PASSINI, Elza Yasuko. Aprendizagem significativa de gráficos no ensino de Geografia. In: ALMEIDA, Rosângela Doin de. (org.) Cartografia escolar. $1^{\underline{a}}$ ed., São Paulo: Contexto, 2008. 
PONCET, Patrick. Visioni del mondo. In: LÉVY, Jacques (org.), Inventare il mondo: una Geografia dela mondializzazione. Disponível em <http://www.inventareilmondo.net/documents/ch_visionidelmondo.pdf> Acesso em 23/08/2011. Tradução de trabalho de Ludmila Girardi-Alves.

PUMAIN, Denise. Distancia. Disponível em: $<$ http://hypergeo.free.fr/article.php3?id_article=162> acesso em: 03/03/2006.

RUBTSOV, Vitaly. A atividade de aprendizado e os problemas referentes à formação do pensamento teórico dos escolares. In: Após Vygotsky e Piaget, perspectivas social e construtivista, escolas russa e ocidental. Trad. Eunice Gruman. Porto Alegre: Artes Médicas, 1996. p.129-137.

SACRISTÁN, José Gimeno. Consciência e ação sobre a prática como libertação profissional dos professores. In Nóvoa, A. (org.) Profissão Professor. Porto, Porto Editora, 1991, p. 63-90.

SANTOS, Milton. Por uma outra globalização: do pensamento crítico à consciência universal. Rio de Janeiro: Record. 2001.

SANTOS, Milton. A Natureza do Espaço, Técnica e Tempo: Razão e Emoção. 4 ed. São Paulo: EDUSP, 2008.

SÃO PAULO (Estado) Secretaria da Educação. Caderno do professor: Geografia, ensino fundamental - 5o série, v.2/ São Paulo: SEE, 2009.

SÃO PAULO (Estado) Secretaria da Educação. Caderno do professor: Geografia, ensino médio - 1aㅗ série, v. 1/ São Paulo: SEE, 2009.

SÃO PAULO (Estado) Secretaria da Educação. Caderno do professor: Geografia, ensino fundamental - 8a série, v. 3/ São Paulo: SEE, 2009.

SÃO PAULO (Estado) Secretaria da Educação. Currículo do estado de São Paulo: Ciências Humanas e suas tecnologias (coord.) Maria Inês Fini. São Paulo: SEE, 2010.

SIMIELLI, Maria Elena Ramos. Cartografia no ensino fundamental e médio, In CARLOS, Ana Fani Alessandri (org.) A Geografia na sala de aula, $4^{\underline{a}}$ ed. São Paulo: Contexto, 2002. p. 92-108.

SIMIELLI, Maria Elena Ramos. O mapa como meio de comunicação e a alfabetização cartográfica, In ALMEIDA, Rosangela Doin de (org.) Cartografia escolar, $1^{\text {a }}$ ed. São Paulo: Contexto, 2008. p.71-93.

SOUZA, Sonia Magali Alves de. A prática pedagógica do professor de Geografia no ensino dos conteúdos cartográficos, dissertação de mestrado apresentada na Universidade Federal de Pernambuco, Recife: 2002. 156 p.

THÉRY, Hervé. A Dimensão Temporal na Modelização Gráfica. GEOUSP - Espaço e Tempo, São Paulo: n. 17, p.171-183, 2005

TORRES, Rosa María. Melhorar a qualidade da educação básica? As estratégias do Banco Mundial. In: TOMMASI, Livia de; WARD, Miriam Jorge; HADDAD, Sérgio (Orgs). O Banco Mundial e as políticas educacionais. 3 ed. São Paulo: Cortez, 2000.

VIGNOLI, Rita Simone Soares. Na prática a Teoria é Outra? Niterói: Dissertação (Mestrado em Educação ), Universidade Federal Fluminense, 2003, 171 p. 
WEISZ, Telma. 0 diálogo entre o ensino e a aprendizagem. $2^{\underline{a}}$ ed., São Paulo: Ática, 2009. 133 p. 